\title{
AVALIAÇÃo dE CENÁRIOS DA PRODUÇÃo AGRÍCOLA VISANDO A SUSTENTABILIDADE DO USO DAS TERRAS DE PIRACICABA (SP)
}

MARIA DO CARMO T. C. LEVY

Engenheira Agrônoma

Orientador: Prof. Dr. GERD SPAROVEK

Dissertação apresentada à Escola Superior de Agricultura "Luiz de Queiroz", da Universidade de Såo Paulo, para obtenção do título de Mestre em Agronomia; Área de Concentração: Solos e Nutrição de Plantas.

P I R A C I C A B A

Estado de São Paulo - Brasil

Agosto - 1995 
CATAL OGAFAD HA PUELICASBO

DIUISAO DE GIGLIOTECA E DOCUMENTAGBO - CAMEUE "LUIZ DE GUEIFOI'/USE

Lew. Maria do Carmo T. C.

Avaliacto de centerius da aroducto auricola visando a sustentabilidade do uso das terras de Piracicatá (SP). Firacicata. 1995.

1045. jlus.

Diss. Mestre\} - ESALQ

gibliugrázia.

1. Agricultura sustentável 2. Cana-de-acúcar - Producóa 3. Usu da terra Avaliaço - Piracicaba l. Escola Superior de Agricultura luiz de Queiroz. Pirácicatá 


\section{AVALIAÇÃO dE CENÁRIOS DA PRODUÇÃO AGRICOLA VISANDO A SUSTENTABILIDADE DO USO DAS TERRAS DE PIRACICABA (SP)}

Aprovada em 5 de outubro de 1995

Comissåo Julgadora:

Prof. Dr. Gerd Sparovek

Prof. Dr.Jairo Antonio Mazza

Prof. Dr. Ricardo Shirota
ESALQ/USP

ESALQ/USP

ESALQ/USP 
Aos meus pais

Carminha e Ian,

Ofereço...

À todos aqueles que de alguma forma contribuem para a liberdade e igualdade dos povos $e$ para a melhoria das condições de vida em nosso planeta Terra Dedico... 


\section{AGRADECIMENTOS}

À Escola Superior de Agricultura "Luiz de Queiroz"- USP pela oportunidade.

Ao Prof- Dr. Gerd Sparovek pelo total apoio, incentivo, amizade e principalmente pela dedicação em todos esses anos de orientação.

Ao Prof. Dr. Jairo Mazza e Prof. Dr Ricardo Shirota, membros da comissão julgadora, pelas sugestões, de fundamental importância para a elaboração deste trabalho.

Ao Prof. Dr. Pablo Vidal Torrado, sempre dando bons conselhos.

Ao Prof Dr Igo Fernando Lepsch, pelas sugestões e por todos esses anos de dedicação à pesquisa.

Aos funcionários do Depto de Ciência do Solo da ESALQ, sempre prontos a colaborar no que for necessário.

À Companhia Suzano de Papel e Celulose, em especial ao Eng. Agr. Paulo Groke, pelo apoio neste trabalho.

Aos amigos Tanaka, Miguel Cooper, Claudio, B.A., por toda a colaboração e paciência.

À BETA, amiga e irmã sempre me apoiando e incentivando.

Ao meu mestre Zequinha, por todos os ensinamentos, principalmente me levando a acreditar mais em meu potencial.

Aos meus irmãozinhos TIN-TIN, DAISY, e toda nossa comunidade por todos os bons momentos juntos.

À todos aqueles que estão sempre prontos a colaborar...

Finalmente, à Coordenadoria de Aperfeiçoamento de Pessoal de Nível Superior (CAPES) pela bolsa concedida.

E à Fundação de Amparo a Pesquisa no Estado de São Paulo (FAPESP) pelo Auxílio a Pesquisa concedido, sem o qual não seria possível a realização deste trabalho. 


\section{SUMÁRIO}

Página

RESUMO

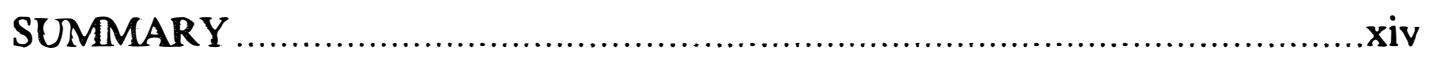

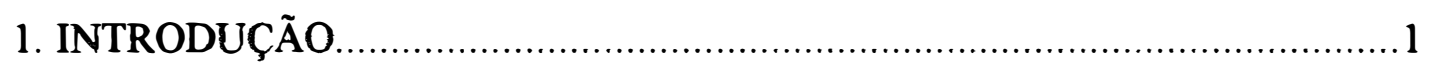

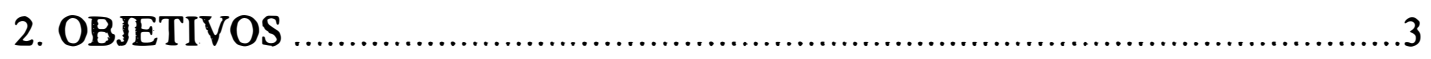

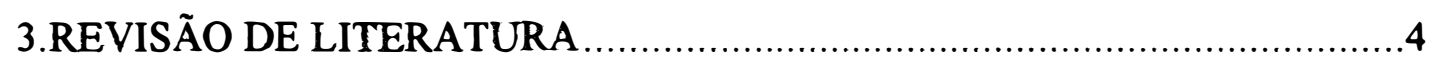

3.1 Planejamento do uso da terra e planejamento ambiental ........................ 8

3.2 Planejamento e sistemas informatizados ..............................................

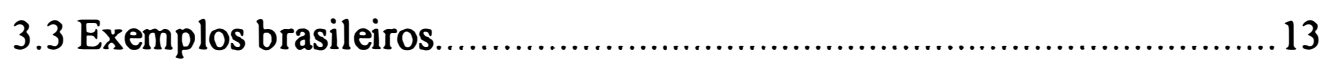

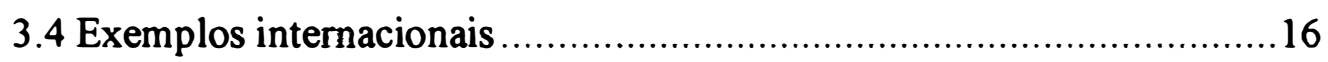

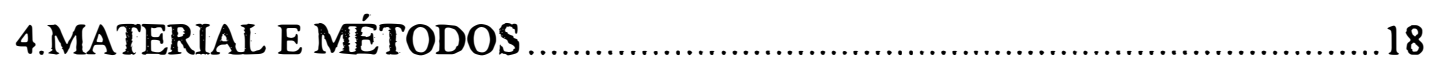

4.1 Avaliação do potencial de utilização das terras ....................................21

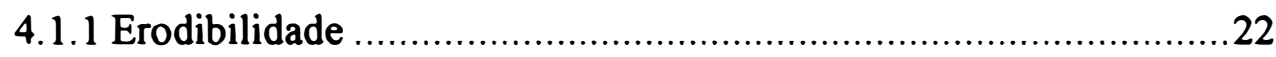

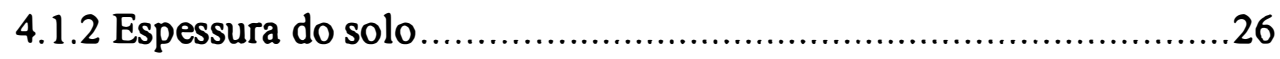

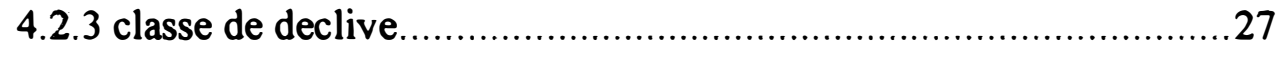

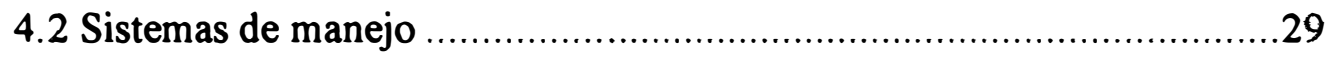

4.2.1 Detalhamento das operações.........................................................

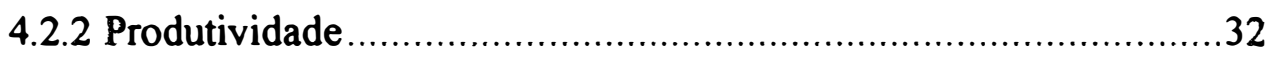

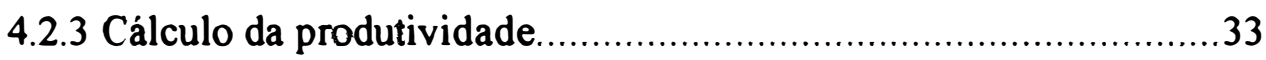

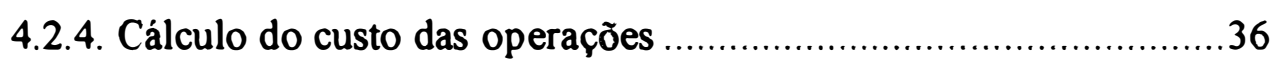

4.2.5 Cálculo da produção e custo total para cada sistema de manejo ....37 


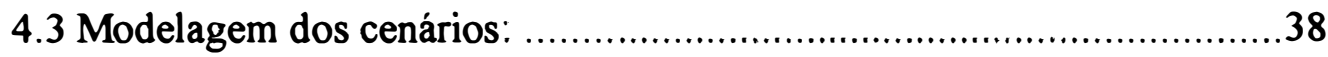

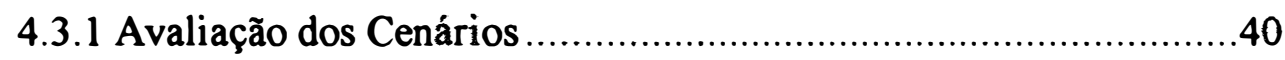

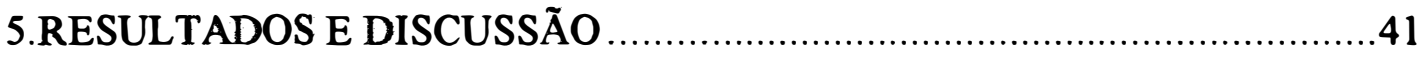

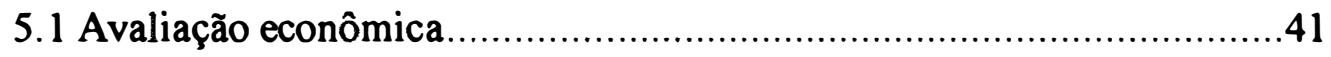

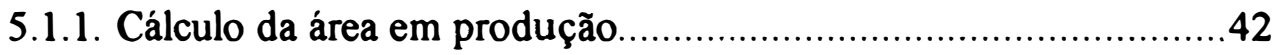

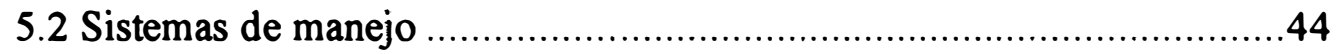

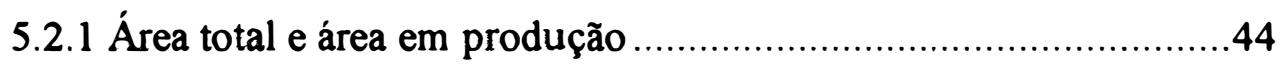

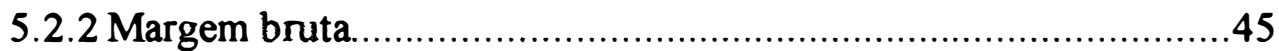

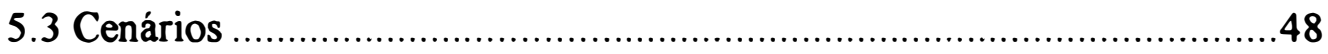

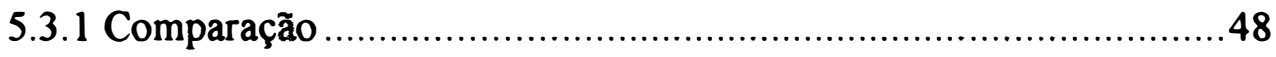

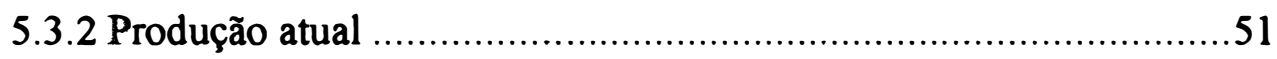

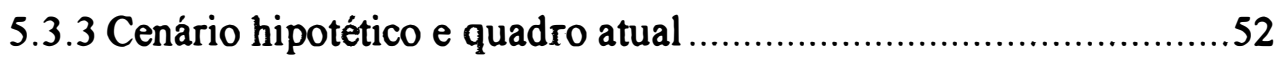

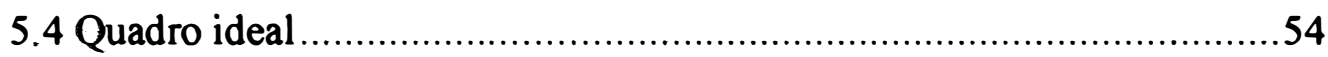

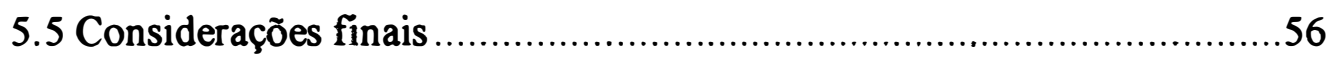

6. CONCLUSÕES

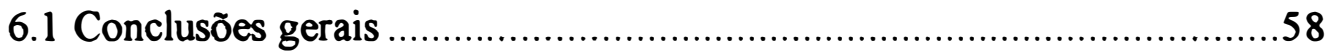

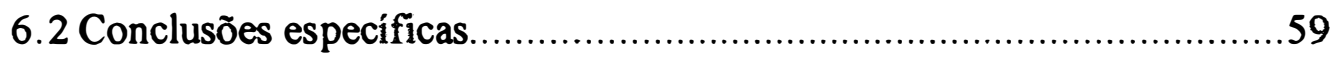

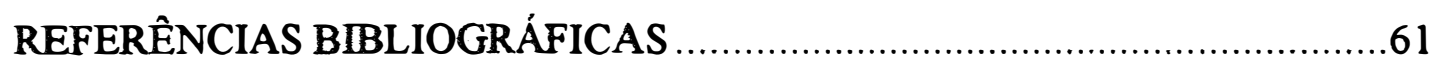




\section{LISTA DE FIGURAS}

Página

Figura 1: Mapa pedológico simplificado das terras de Piracicaba (SP) ..................20

Figura 2: Erodibilidade estimada das terras de Piracicaba. ..................................25

Figura 3: Potencial de uso das terras de Piracicaba para a cultura da cana-de- açúcar

Figura 4: Cenários de ocupação crescente com cana-de-açúcar nas terras de Piracicaba..... 39

Figura 5: Comparação entre as áreas de produção de cana-de-açúcar em 1991 e o

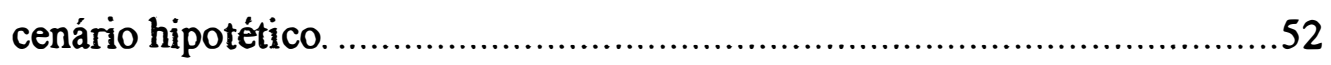




\section{LISTA DE TABELAS}

\section{Página}

Tabela 1: Diâmetro médio de cada classe textural pela escala $P h i$

Tabela 2: Classificação do índice de erodibilidade (K).

Tabela 3: Critérios para avaliação do potencial de uso das terras de Piracicaba para a lavoura de cana-da-açúcar .28

Tabela 4: Ocorrência das principais classes de solos agnupadas e o sistema de manejo correspondente para a cultura da cana de açúcar 30

Tabela 5: Atributos do solo relacionados a sua fertilidade em função do grau de limitação à produtividade da cana-de-açúcar 34

Tabela 6: Valor atribuído ao grau de limitação do componente fertilidade 35

Tabela 7: Valor atribuído à avaliação da espessura do solo .35

Tabela 8: Valor atribuído à avaliação da disponibilidade hídrica 35

Tabela 9: Índices econômicos relativos aos cenários: 49

Tabela 10: Comparação entre as áreas de produção de cana-de-açúcar em 1991 e o cenário hipotético 


\section{LISTA DE GRÁFICOS}

\section{Página}

Gráfico 1: Área total e área em produção efetiva

Gráfico 2: Margem bruta relativa aos sistemas de manejo por ha total/ano .45

Gráfico 3: Despesas relativas aos sistemas de manejo em U\$ por ha por ano....46

Gráfico 4: Despesa, receita, margem bruta e produção total por sistema de manejo .47

Gráfico 5: Índices relativos aos cenários. 49 


\title{
AVALIAÇÃo de CENÁRIOS dA PRODUÇÃO AGRÍCOLA VISANDO A SUSTENTABILIDADE DO USO DAS TERRAS DE PIRACICABA (SP)
}

\author{
Autor: Maria do Carmo T.C. Levy \\ Orientador Pof. Dr. Gerd Sparovek
}

RESUMO

O planejamento da ocupação espacial é de fundamental importância para a prática de uma agricultura sustentável. Assim, a avaliação de terras é uma importante etapa deste processo pois permite estimar o potencial das terras e o nível tecnológico para o desenvolvimento das atividades agrícolas, bem como o nível de tecnologia necessário. A ocupação racional das terras deve considerar a utilização de tecnologias que garantam uma produção rentável com um mínimo de degradação ambiental. Nesta avaliação é desejável reduzir ao máximo a subjetividade na tomada de decisões.

Dentro deste contexto e a partir de informações do meio fisico do município de Piracicaba foi desenvolvido um método analítico para a avaliação do potencial de uso das terras utilizando informações temáticas usuais, como solos (Levantamento pedológico da quadrícula de Piracicaba e dados analíticos correspondentes), declividade (mapas IBGE), e uso das terras e um sistema de análise de mapas temáticos (GMAP).

Como cultura prioritária considerou-se a cana-de-açúcar, por ocupar grande parte das terras do municipio e por sua importância econômica para a região. Foram selecionados então os parâmetros mais relevantes para o manejo desta cultura.

Inicialmente considerou-se a erodibilidade das terras, utilizando a equação de estimativa de erodibilidade (K) desenvolvida por DENARDIN (1990), classificando-a em 
alta $(>0,0318$ t. ha h/ ha Mj mm), média $(0,0318-0,0247$ t. ha h/ ha Mj mm) e baixa < 0,0247. t. ha h/ ha Mj mm).

Posteriormente foram sobrepostos os mapas de erodibilidade, de profundidade dos solos, (solos rasos: $<0,5 \mathrm{~m}$, médios: 0,5 a $1,0 \mathrm{~m}$ e profundos $>1,0 \mathrm{~m}$ ) e de declividade, gerando o mapa de potencial das terras de Piracicaba para a cultura da cana-de-açúcar.

Foram estabelecidas as classes Muito alto, Alto, Médio, Baixo e Muito baixo.de potencial de uso das terras para o cultivo da cana de açucar. A partir daí foram listadas e quantificadas as unidades de mapeamento ocorrentes em cada classe de potencial e posteriormente essas foram agrupadas de acordo com semelhanças entre si quanto a características que determinam o seu manejo. Assim, para cada grupo de solos foram listadas as principais operações desde o preparo do solo até a colheita da cultura da canade-açúcar. À esse conjunto de operações foi dado o nome de Sistema de manejo. Cada operação teve o seu custo determinado, calculando-se então o custo de implantação, manutenção e colheita para os Sistemas de manejo. Estimou-se a produção total em t/ano, a margem bruta total em U\$/ano, a receita total em U\$/ano e a margem bruta total em U\$/ha ano.

Tendo como base as classes de potencial de uso das terras para a cana-de-açúcar, foram montados cinco cenários com ocupação crescente das terras: partindo do cenário 1 com ocupação apenas das áreas com potencial Muito alto, até o cenário 5 , com ocupação até potencial Muito baixo, ou seja, todas as áreas. Para a avaliação econômica e comparação dos cenários foram considerados os índices econômicos relativos aos sistemas de manejo que estariam sendo praticados nas áreas ocupadas.

Com a análise dos cenários concluiu-se que conforme a ocupação com a cana-deaçúcar se estende a áreas de potencial mais baixo, apesar da produção total estar aumentando, a margem bruta média por ha ano diminue. Se for considerado cada Sistema 
de manejo individualmente esta situação se acentua. Assim conforme o potencial das terras se torna menor os rendimentos diminuem, indicados pela redução da margem bruta total por hectare ano.

Como a agricultura praticada normalmente tem o objetivo de lucros imediatos, a curto prazo, é de se pressupor que nos casos em que a ocupação está sendo feita nas áreas de potencial menor nas quais deveriam estar sendo tomadas medidas conservacionistas mais intensas e mais caras, essas não estão sendo praticadas devidamente. Nessa agricultura visando a maximização dos lucros e a minimização dos custos por hectare ano, muitas vezes o aspecto conservacionista não é devidamente considerado.

Esta situação que a curto prazo gera maiores rendimentos, a longo prazo pode estar causando sérios prejuízos ambientais, tanto a nível da terra em questão, refletindo por uma diminuição na produtividade, quanto ao ambiente, aumentando a quantidade de sedimentos transportados para rios e reservatórios d'agua, diminuindo a quantidade de água e piorando sua qualidade para o consumo, aumentando os custos do seu tratamento, bem como outros prejuízos ambientais dificeis de serem quantificados monetariamente.

A comparação entre a estimativa de produção atual do município (safra 1995/6), e a produção relativa aos cenários de ocupação, indicou que poderiam estar sendo utilizadas para o cultivo da cana-de-açúcar apenas as áreas com potencial elevado, (cenário $2+$ Sistemas de manejo 5a e 5b) para atingir produção total. Nestas áreas o risco de degradação é menor e a margem bruta por ha ano é maior. Deste modo, as áreas que tem um potencial menor, poderiam estar sendo utilizadas com outras culturas que eventualmente poderiam possibilitar rendimentos maiores e ao mesmo tempo com menores riscos de degradação ambiental.

Portanto, se a ocupação das terras com cana-de-açúcar no município de Piracicaba fosse feita de maneira planejada, isto é, a escolha do uso das terras de acordo com o seu 
potencial, poderia ter-se níveis mais elevados de rendimentos por área com um menor risco de degradação ambiental. Ao mesmo tempo esta ocupação respeitando-se o potencial das terras não implica necessariamente em diminuição de produção total, pois como foi indicado é possível manter os atuais níveis de produção de cana-de-açúcar utilizando apenas as áreas de potencial mais elevado para esta cultura. 


\section{Evaluation of agricultural production scenarios aiming the sustainable land use of Piracicaba (SP)}

Author: Maria do Carmo T. C. Levy Adviser: Dr. Gerd Sparovek

\section{SUMMARY}

The space ocupation planning is of fundamental importance for the pratice of sustainable agriculture. Thus, land evaluation is an important phase of this process as it allows us to estimate the potencial and the technological level for the development of agricultural activities. The rational occupation of land must consider the use of technologies that guarantee a profitable production with a minimum environmental degradation. In this evaluation it is desirable to reduce to a minimum the degree of subjectiness in decision making.

In this context and based on information of the physical environment of the Piracicaba district, an analytical method was developed for the potential land use evaluation. Using common tematic information, as soils (Piracicaba district soil survey and corresponding analytical data), slope declivity (IBGE maps), land use and a tematic map analisys system (GMAP).

Sugar cane was considered as a priority crop, as it occupies large areas of the district and because of its economical importance in the region. Thus, the most relevant parameters of this crop were chosen. 
Initially, land erodibility was considered. To estimate land erodibility an equation developed by DENARDIN (1990) was used. It was, classified in three categories: high (> $0,0318 \mathrm{tha} \mathrm{h} / \mathrm{ha} \mathrm{Mj} \mathrm{mm})$, medium $(0,0318-0,0247 \mathrm{tha} \mathrm{h} / \mathrm{ha} \mathrm{Mj} \mathrm{mm})$ and low $(<0,0247$ $\mathrm{tha} / \mathrm{ha} \mathrm{Mj} \mathrm{mm}$ ).

Later, the erodibility maps, soil depth and slope declivites were superposed originating a land potential map for Piracicaba for the sugar-cane crop.

The classes very high, high, medium, low and very low were established for the potencial land use of sugar-cane. Based on these classes, the mapping units that occur in each potential class were listed and quantified. Later these were grouped according to similarities between the classes and characteristics that determine their managgement. Thus, for each group of soils the main operations from sowing to the harvest of the sugarcane were listed. To this group of operations the name managgement system was given. Each operation had its costs determined. The cost of implantation, maintenance and harvest was then calculeted for each managgment systems. The total production in $t / y e a r$, the total gross margin in U\$/year, the total income in U\$/year and the total gross margin in U\$/ha year were estimated.

Based on the land use potential for sugar-cane, five scenarios were defined in a accordance to the growing land occupation: beginning with scenario 1 with occupation of the lands with very high potential, up to scenario 5, with occupation even of the low potential areas, that means all the areas. For an economic evaluation and scenarios comparison economic indexes related to the managgment systems that were considered.

With the scenarios analisys it is concluded that as the occupation with sugar-cane extends to the areas of lower potential, the mean gross margin per ha year declines.

If each management systems is consideraded individually, this situation worsens. 
So, as the land potential reduces the yields are lower. This is shown by the reduction of the total gross margin per hectare per year. As the agriculture that is practised normally has the objetive of immediate profits, it is expected that in the areas in which the occupation is done in areas with low potential were intense and more expensive conservation measures should he taken. These are not put into practice so as to reduce the costs per hectare year with the objective of preserving profitability. This situation that in the short run generates highest profits, in the long run could be causing environmental degradation, increaring the amount of sediments transported to the rivers and water reservoirs, diminishing the quantity of water and worsening its quality for consumption, increasing the treatment costs, as well as other environmental damages difficult to be quantified monetarily

The comparison between the estimate of the districts actual production (1995/6), and the relative production of the occupation scenarios, showed that the only areas that can be used with sugar-cane are the areas with high potential (scenario $2+$ managgment systems $5 \mathrm{a}$ and $\mathrm{5b}$ ) to reach total production. In these areas the risc of degradation is lower and the gross margin per ha year is higher. In this way, the areas with a lower potential could be used with others crop that eventually could give higher yields with lower risks of environmental degradation.

If the occupation of the lands of the district of Piracicaba with sugar-cane were done in a planned way, this means the land use considering its potential, there would be a much lower risk of environmental degradation, generating higher profit per area. At the same time, this occupation respecting the land potential doesn't necessarily imply in the decrease of production, because as it was shown it is possible to maintain the actual levels of sugar-cane production using only the areas with the highest potential for this crop. 


\section{INTRODUÇÃO}

A manutenção da capacidade produtiva do ecossistema agrícola e a preservação ambiental dependem em grande parte do uso racional dos recursos naturais. Neste sentido, o conhecimento dos solos, do clima, da vegetação, da água, do relevo e dos condicionantes socio-econômicos como a produção, a população, a evolução da fronteira agrícola e do uso das terras, constituem embasamento indispensável. Essas informações possibilitam avaliar o potencial de uso das terras, para a diferenciação das áreas passiveis de utilização com atividades agrícolas sustentáveis daquelas que não o são.

Atualmente define-se agricultura sustentável, como sendo aquela que permite a manutenção dos niveis de produtividade a curto e longo prazos, sem levar ao esgotamento dos recursos naturais. GOLLEY et al. (1993) referem-se a sustentabilidade como o manejo dos recursos naturais pelas populações humanas de maneira a permitir que a vida possa continuar a evoluir no planeta, sem o esgotamento desses recursos.

A intervenção humana em um ecossistema natural pode provocar desequilíbrios de intensidade variável, de acordo com o tipo de interferência. Assim, a ocupação racional das terras deve considerar a utilização de tecnologias que garantam a máxima produção compatível com um mínimo de degradação ambiental, possibilitando a manutenção da produtividade ao longo do tempo. 
No entanto, a agricultura praticada atualmente, muitas vezes não se enquadra no conceito de sustentabilidade, por visar lucros momentâneos e não considerar o possível declínio da produção devido a depauperação dos recursos naturais.

Neste contexto, o presente trabalho pretende demonstrar as vantagens do planejamento ambiental. Na agricultura planejada são respeitadas as potencialidades das terras e os condicionantes socio-econômicos o que deve proporcionar aumento nos rendimentos e a não degradação dos recursos naturais

Pretende-se por comparação de cenários, nos quais serão testados crescentes níveis de ocupação das terras do município de Piracicaba para a produção de cana-deaçúcar, avaliar e estimar os efeitos ambientais e econômicos destas ocupações. 


\section{OBJETIVOS}

Desenvolver um método analítico para avaliação do potencial do uso das terras de Piracicaba, tendo como enfoque central a cultura da cana-de-açúcar. Esta avaliação deverá ser feita automaticamente, utilizando sistemas informatizados procurando reduzir ao máximo a subjetividade nas avaliações.

Avaliar, por simulação de cenários com ocupação crescente das terras com cana-de-açúcar a ocupação em diferentes condições de potencial para esta cultura no municipio.

Comparar o atual uso das terras no município de Piracicaba com o potencial de uso destas para a cana-de-açúcar avaliar a tendência da atual ocupação das terras.

Demonstrar que muitas vezes apenas o remanejamento de áreas destinadas às culturas ou um manejo conservacionista adequado pode permitir a manutenção ou o aumento na produção total de forma sustentável.

Finalmente, demonstrar que o uso das terras respeitando-se seu potencial natural é mais favorável ambientalmente e economicamente. 


\section{REVISÃO DE LITERATURA}

(d) Segundo DIEGUES (1989), o conceito de desenvolvimento sustentável parte do princípio de que o uso dos recursos ambientais deve respeitar a manutenção dos processos vitais dos ecossistemas, em beneficio das gerações atuais e futuras. Ao mesmo tempo em que se baseia nas potencialidades e vocações naturais dos ecossistemas, pressupõe uma distribuição equitativa dos beneficios do crescimento econômico A própria estratégia mundial para a conservação da IUCN (União Internacional para Conservação da Natureza), define desenvolvimento sustentável como o processo de mudança no qual a exploração dos recursos, o direcionamento dos investimentos, a orientação do desenvolvimento tecnológico e as mudanças institucionais se dirigem à satisfação das necessidades das gerações presentes, sem comprometer a possibilidade das gerações futuras satisfazerem as suas.

Em trabalho recente, RYFF (1995) define o desenvolvimento sustentável como aquele capaz de (a) alimentar uma população mundial crescente, (b) sustentar o nível de renda das famílias que deverão permanecer na atividade agropecuária, (c) preservar a capacidade da terra de produzir alimentos e matérias-primas agrícolas em benefício das futuras gerações e (d) garantir que a atividade agropecuária reduza seus efeitos externos negativos no que diz respeito à preservação e a recuperação do ambiente.

A exploração inadequada das terras e a destruição de vegetação natural expõe a superficie aos agentes erosivos. Em civilizações antigas como a Mesopotâmia, entre os rios Eufrates e Tigre, o assoreamento dos canais de irrigação causado pelo manejo 
inadequado das terras e desmatamento, contribuiu sensivelmente para o declínio destas civilizações, transformando suas terras em desertos (BENNETT, 1939 e HOLÝ, 1984).

Existem outros relatos de civilizações antigas que tiveram seu declínio associado a degradação dos recursos naturais como solo e água. São exemplos a Síria e a Arábia Saudita, que antigamente possuiam terras férteis e produtivas e hoje são áridas. 0 próprio império Maia sofreu sérias consequências pela perda do potencial produtivo de suas terras ocasionando a migração da população em direção ao norte da América do Sul (BENNETT, 1939).

( $*$ O Brasil por estar em condiçōes de clima tropical e subtropical, com muitas áreas com condições edáficas desfavoráveis à agricultura ou alta declividade, está fortemente sujeito à ação dos agentes causadores do processo erosivo. Condições estas muitas vezes agravadas pela ação do homem, acelerando a erosão hídrica com suas práticas inadequadas de agricultura (BERTONI \& LOMBARDI NETO, 1990). *

Segundo RESENDE et al. (1988), o Brasil apresenta a maior parte de seu território composto por latossolos, porém estes nem sempre se encontram em áreas com agricultura intensiva, possuindo muitas vezes baixissima fertilidade natural, ou limitações fisicas de uso. Solos com horizonte B textural, ou solos rasos, apesar de não serem os mais representativos em termos de área total encontram-se juntamente com alguns latossolos justamente nas regiōes tradicionalmente agricolas. Esses solos são os mais problemáticos em termos de erosão e , nestes casos são necessários maiores cuidados quanto ao manejo e conservação.

¿Para RYFF (1995), as duas maiores ameaças à preservação da capacidade produtiva das terras são a erosão e adoção de técnicas excessivamente intensas de cultivo, podendo estes dois fatores virem associados. Isto é a erosão pode estar associada ao intenso uso agrícola sem as técnicas conservacionistas adequadas. . . 
Em 1939, BENNETT já alertava para o problema da degradação das terras nos EUA devido ao manejo inadequado. Segundo ele, este era um dos problemas mais urgentes da agricultura a ser solucionado naquela época. $\mathrm{O}$ autor faz menção a uma agricultura permanente, sendo esta possível somente se a sociedade pagar o preço de conservar a terra. Compara também exemplos onde o preço não foi pago, e como resultado deu-se o desaparecimento de civilizações.

Nessa época BENNETT (1939) falava em pagar o preço da conservação, devendo este estar implícito no preço dos produtos. Atualmente isso tem sido muito questionado, colocando-se em discussão a questão da cobrança dos recursos naturais consumidos no processo produtivo. Muita vezes se fosse incluído no preço de alguns produtos o custo dos recursos consumidos no seu processo produtivo, estes teriam um rendimento negativo.

Além disso, RYFF (1995) aponta que a não utilização de técnicas de preservação e recuperação do solo não constitue somente uma perda ecológica externa a propriedade, mas a degradação de um capital produtivo que pode afetar o valor presente de mercado da terra e que na melhor das hipóteses reduzirá significativamente o valor econômico da propriedade a ser legado a herdeiros. Porém, para disseminação entre os agricultores das técnicas de conservação e recuperação dos solos é necessário estar presente dois elementos de política agrícola: o fornecimento de informações adequadas e a disponibilidade de crédito para a adoção destas técnicas, cujo retorno pode ser relativamente lento por parte dos agricultores.

(6) $*$ Na própria região de Piracicaba, RANZANI, (1964) observava que a introdução e difusão da cultura canavieira precedeu à eleição das áreas mais adequadas a esta gramínea, avaliando que os prejuízos desta antecipação poderiam levar a sérias 
consequências sociais e ambientais. Por fim ressalta a necessidade de um planejamento agro industrial na região. *

Diante do exposto, tentando evitar que fatos ocorridos no passado se repitam, é clara a necessidade de se fazer uma ocupação pensada, estudada e planejada das terras. Embora aparentemente uma preocupação que já vem desde o passado, pouco se tem feito neste sentido, em termos de pesquisa e extensão no Brasil.

Informações espaciais são um requisito necessário para o controle e ordenação da ocupação das terras. Essas muitas vezes sofrem pressões de ocupações incompatíveis com suas aptidões naturais. Somente com o conhecimento do potencial de utilização e a localização destas áreas pode-se propor alternativas de uso compatíveis com o meio fisico.

Métodos de levantamento dos recursos naturais tem sido muito estudados nas Universidades e Instituições de Pesquisa tendo a necessidade de preservação destes recursos sido comprovada por muitos estudos econômicos e ambientais. Entretanto, poucos são os esforços no sentido de levar estes conhecimentos aos órgãos de planejamento governamental e aos setores produtivos. Ao mesmo tempo, muitas vezes esses órgãos ou setores produtivos não se mostram interessados em aplicar esses conhecimentos no seu efetivo planejamento.

O planejamento municipal é de extrema importância, sendo peça fundamental para os Planos Diretores de Desenvolvimento. Geralmente, porém dá-se maior importância para o aspecto urbano, talvez por um caráter mais urgente, havendo poucos trabalhos a nivel municipal qie abordem a área total destes. Na região de Piracicaba (SP) foi elaborado um Plano Diretor de Desenvolvimento em 1991 contendo basicamente os fatores mais pertinentes ao desenvolvimento urbano. Porém neste Plano Diretor é 
apontada a necessidade de se avançar no processo de planejamento rural, sem contudo definir uma estratégia específica para isto (PIRACICABA, 1992).

Com Sistemas de Informações Geográficas pode-se armazenar e manipular diferentes modalidades de informações temáticas de uma região, relacionando-as a aspectos socio-econômicos, climáticos e outros, possibilitando uma agilidade e facilidade na manipulação e cruzamento de informações, o que fornece maior precisão nos dados.

Deste modo, é clara a necessidade de se efetuar um estudo enfocando o município como um todo, com dados atualizados e de fácil acesso. Este estudo poderá servir de referência a vários setores como à extensão, definindo as áreas mais aptas a serem instaladas ou mantidas determinadas culturas e à pesquisa, permitindo o seu direcionamento para áreas com características que se adaptem melhor aos objetivos propostos pela pesquisa ou apontando problemas específicos que podem ser estudados.

\subsection{Planejamento do uso da terra e planejamento ambiental}

BRANDT \& OLIVEIRA (1973) definem o planejamento como a maneira de prever o mais detalhadamente possível o que vai acontecer, de modo que todas as ações e tomadas de decisões sejam feitas no tempo e lugar certo.

De acordo com DIEPEN et al.(1991), a avaliação de terras é o estudo da aptidão do uso desta. Para manter a avaliação de terras no seu sentido mais amplo é necessário a integração de várias disciplinas.

LORANDI (1985), em trabalho feito na região de São Carlos, enfatiza a importância do levantamento pedológico para o aproveitamento racional dos recursos naturais, bem como o aspecto de cada tipo de levantamento ser feito em função de uma necessidade e objetivo específico. 
Existem trabalhos como o de ARAÚJO (1988), que tem como objetivo servir de marco de referência a órgãos públicos e/ou privados. Realizou-se na região da baixada ocidental maranhense um estudo do uso da terra, força de trabalho e população, equipamentos públicos e privados existentes, produção agropecuária e tipo de tecnologia utilizada, para diagnóstico da região. Este serviu para orientar programas de investimentos, fazendo parte de um programa de apoio ao pequeno produtor rural

OLIVEIRA (1988) relacionou o ambiente agrícola (fertilidade de solos, quimica e mineralogia, água no sistema, etc) com a evolução das relações de produção, caracterizando o que chamou de etnopedologia. 0 autor sugere o termo para o èstudo da relação entre o tipo de ocupação das terras e o sistema agrícola adotado pela comunidade, com os recursos naturais disponiveis, sendo estes os principais condicionantes da ocupação.

FAETH (1993) define agricultura sustentável, como aquela que garante manutenção da produtividade e lucratividade associada a uma minimização de impactos ambientais.

Sustentabilidade significa que a atividade econômica deve satisfazer as necessidades presentes sem comprometer as futuras. Deste modo o consumo de recursos naturais deve respeitar este preceito (DIEGUES, 1989). O desenvolvimento agrícola sustentável conserva os recursos genéticos, não degrada o meio ambiente, é apropriado tecnicamente, viável economicamente e aceitável socialmente (FAO, 1990). $\propto$

Porém a prática da agricultura atual nem sempre se enquadra nestas definições pois os sistemas de produção muitas vezes ignoram o que podem estar causando aos recursos naturais como solo e água. Por outro lado tanto a agricultura como outros setores econômicos dependem da saúde destes recursos. Fazendeiros calculam a depreciação de suas máquinas, mas ignoram as perdas de produtividades devido ao 
esgotamento de recursos. O solo pode ser erodido, lençóis freáticos contaminados, fauna desaparecer e reservatórios serem assoreados, mas normalmente nenhuma depreciação é aplicada sobre a degradação destes recursos (FAETH, 1993).

Segundo RUBIO et al. (1989), a adaptação do uso das terras às suas limitações é um dos mais baratos e efetivos meios de conservação dos recursos naturais.

No estado do Paraná, cuja ocupação desde o início da colonização sempre se caracterizou por um modelo imediatista, decorrente quase sempre da ação de estímulos econômicos e políticos, observa-se uma situação de alta degradação das terras, refletida em alguns casos por uma acentuada redução na produtividades das culturas. A área ocupada por culturas anuais no Paraná em 1984 era estimada em 6.000.000 ha. Considerando-se uma perda média de solo de 20 tha/ano, e considerando apenas o nitrogênio, fósforo, cálcio e magnésio perdidos, os custos anuais das perdas destes nutrientes chegam a 193 milhões de dólares anuais aproximadamente. Em função disto, minerais do solo e defensivos agrícolas que chegam aos rios do Paraná devido às enxurradas e à erosão exessiva são os principais causadores da poluição das águas. Esta poluição vem afetando a qualidade da água para consumo humano e animal, encarecendo o custo de tratamento desta (PARANÁ, 1987). Porém, atualmente este quadro está sendo revertido graças ao manejo conservacionista de algumas áreas por parte de iniciativas públicas e privadas.

Quanto a aspectos econômicos, existem trabalhos como o de CORTINA (1992), que tem como enfoque principal a necessidade de planejamento econômico da empresa agrícola moderna, principalmente a partir de 1990 quando a maioria dos subsídios para a agricultura foi cortada. No planejamento deve ser levado em conta a situação conjuntural do meio e isto implica em estrutura e recursos disponíveis, Neste contexto o conhecimento dos recursos naturais é de importância fundamental. 
Segundo FAETH (1993) métodos de contabilização de recursos naturais são um excelente meio de se medir a sustentabilidade de um sistema. Com índices econômicos o autor compara sistemas de produção convencional com sistemas alternativos, contabilizando os recursos naturais envolvidos. Com a criação de um método analítico que quantifica os custos e beneficios econômicos e ambientais dos sistemas agrícolas, é possível se comparar as consequências de intervenções políticas, transferências de custo ambiental nas fazendas em termos fisicos e monetários bem como quais os custos e beneficios de políticas ambientais comparadas.

SILVA et al. (1993) ressalta a importância do processamento georeferenciado quando integrado a dados extraídos de sensoriamento remoto, podendo ser extremamente útil na avaliação e planejamento da exploração sustentável e duradoura dos recursos naturais.

\subsection{Planejamento e sistemas informatizados}

É clara a necessidade de um planejamento para a ocupação agrícola e urbanização com um mínimo impacto. Sistemas de Informações Geográficas (SIG) podem ser considerados um auxílio no planejamento, como demonstrado em exemplos na Florida e em Massachusetts, citados por DAVIDSON (1992). É fundamental a importância dos SIGs para o armazenamento e manipulação de dados sobre a evolução do uso das terras, monitoramento de mudanças que eventualmente ocorram, alterações no modelo de ocupação agrícola e possibilidade de expansão de determinadas culturas.

Segundo FORMAGGIO et al.(1992), a disponibilidade de um método semi automático e não subjetivo para a obtenção da aptidão agrícola associado à verificação periódica do uso da terra e a comparação com uso ideal (adequação de uso), seria um 
importante instrumento para as entidades conservacionistas e de planejamento poderem monitorar e propor opções para o uso das terras.

Para LOPES ASSAD (1995) uma das grandes dificuldades na avaliação das terras para fins de manejo consiste em definir um método que a partir da dinâmica ambiental, permita estimar o comportamento do meio quando submetido a um dado manejo. Essa dificuldade se torna bastante evidente em áreas onde a ocupação acelerada exige rapidez na caracterização da aptidão da terra e da sua capacidade de suportar os impactos provocados pelo uso. Neste sentido a utilização de SIGs, vem permitindo o zoneamento de áreas de forma mais eficiente, substituindo os métodos tradicionais de análise quase sempre mais onerosos e de manipulação mais dificil.

VENTURA et al. (1993) citam que nos Estados Unidos da América os órgãos oficiais estão procurando a tecnologia da informática, em especial dos SIGs, para facilitar o armazenamento de informações e prover qualidade e eficiência aos programas conservacionistas implementados pelo governo.

Os SIGs fornecem informações que auxiliam na tomada de decisões quanto ao tipo de investimentos, e onde investir em sistemas conservacionistas (DAVIDSON, 1992 e VENTURA et al., 1993).

Muitas são as vantagens de utilização de SIGs, como localização específica dos fenômenos, possibilidade de estudos em áreas extensas envolvendo muitas variáveis, fácil acesso e rapidez na manipulação de dados (DAVIDSON, 1992 e TEIXEIRA et al., 1992).

Os Sistemas de Informação Geográfica provém cientistas, planejadores e políticos de um eficiente meio de combinações e análises georeferenciadas e descritivas dos recursos naturais, para um melhor entendimento e manejo das terras (FERNANDEZ et al., 1993). Dados geograficamente referenciados podem ser manipulados, analisados 
estatisticamente, avaliados arquivados, recuperados e instantaneamente reproduzidos em mapas e tabelas (SILVA et al., 1993).

DAVIDSON (1992) cita que em meados da década de 80 envolveu-se com planejamento regional para demonstrar o potencial de utilização dos SIGs em planejamento estratégico e, apesar de um grande número de informações terem sido geradas, grande parte foi ignorada, sendo a causa principal a não adaptabilidade das informações geradas a necessidade dos planejadores locais.

Um problema colocado por VENTURA et al. (1993), é que apesar da utilização dos Sistemas de Informação Geográfica terem potencial para agilizar muitos tipos de informação, sua implementação exige substancial esforço, principalmente no que se refere a tempo para automatização dos dados, treinamento de pessoal, organização, etc. Sob o aspecto dos equipamentos necessários, geralmente são sofisticados, caros e de dificil operação, exigindo técnicos especializados.

\subsection{Exemplos brasileiros}

KOFFLER \& MORETTI (1991), em trabalho no município de Rio Claro (SP) procuraram estabelecer um quadro idealizado do uso agrícola das terras, de acordo com sua aptidão natural, em função das exigências ambientais de culturas agrícolas tradicionalmente cultivadas na região. Como base de dados foram utilizadas cartas geológicas da região (IPT), mapa de solos na escala 1:100.000 (OLIVEIRA \& PRADO, 1989), e uso das terras com base em fotografias aéreas. Através destes dados foram gerados mapas de classe de declive e aptidão agrícola, e estas informaçōes confrontadas com a situação de uso atual. Estas informações foram cruzadas e analisadas por um Sistema de Informações Geográficas "GEO-INF \& MAP" desenvolvido por TEIXEIRA (1989) compativel com microcomputadores do tipo IBM-PC. Como resultado foram 
obtidos mapas de terras aptas para determinadas culturas, reflorestamentos e pastagens, suas áreas e a representatividade no município. Posteriormente as áreas foram divididas em grupos de manejo com semelhantes características edáficas e semelhante grau de investimento necessário para a otimização agricola da área.

Anterior a esse trabalho, já existia na área urbana de Rio Claro um zoneamento feito por COTTAS (1983), em sua tese de doutoramento. Agrupando diversas informações de meio físico, elaborou-se uma carta de orientação para a sua ocupação, definindo as áreas mais apropriadas para diferentes usos da terra.

ASSAD \& SANO (1993) descrevem um planejamento realizado no município de Silvânia, GO, no qual dados de solos, declividade e uso das terras foram manipulados em um SIG, analisando-se a ocupação e expansão da fronteira agrícola na região. Com esses dados básicos e dos cruzamentos obtidos com o SIG, efetuou-se a caracterização do município e de 12 comunidades pertencentes a este. A área estudada foi de 362.000 ha e o município apresentou uma produção econômica diversificada, heterogeneidade no tamanho das propriedades e variação no uso da força de trabalho. $\mathbf{O}$ objetivo principal do trabalho seria auxiliar os produtores rurais através de uma maior integração entre pesquisa e extensão rural. Como resultado, identificou-se e qualificouse o aumento das áreas cultivadas entre 1978, 1981 e 1986, concluindo ter a ocupação de novas áreas para plantio sido feita de forma desordenada, sem respeito à aptidão das terras.

SILVA et al. (1993), com o objetivo de detectar as áreas e o risco à integridade do meio ambiente e de dar suporte à prevenção do uso inadequado dos solos, desenvolveram uma análise temporal do uso da terra na região de Ubajara (CE) em um período de 27 anos. Para tanto, utilizaram-se de dados extraidos de fotografias aéreas, imagens TM/Landsat 5, e mapas de levantamentos de solos, todos processados e 
sobrepostos em um Sistema de Análise Georeferenciada. Este sistema se mostrou muito útil na visualização das variações espaciais e temporais de uso da terra e aperfeiçoou o armazenamento e a manipulação de dados para decisões que conduzam à conservação do solo e da água.

LOPES ASSAD (1995), realizou um estudo na Fazenda Experimental da Universidade de Brasília com o objetivo de definir um método para determinação da aptidão agrícola das terras para três níveis de manejo, a partir das informações obtidas por levantamento de solos e utilizando o Sistema de Informações Geográficas desenvolvido pelo Instituto Nacional de Pesquisas Espaciais (SGI/NPE). Com este trabalho pretendeu-se contribuir para a automatização da determinação da aptidão agrícola de terras, utilizando apenas dados disponíveis provenientes de levantamento de solos e de cartas planialtimétricas.

No Plano Diretor de Desenvolvimento de Piracicaba elaborado em 1991, foi apontada a necessidade de se avançar no processo de planejamento, sem contudo definir uma estratégia específica para isto (PIRACICABA, 1992). Neste documento é apresentado um estudo da tendência geral de desenvolvimento dos municípios pertencentes a bacia do Rio Piracicaba nos últimos anos, não havendo maiores especificações quanto ao tipo de ocupação das terras, nível de tecnologia utilizada, produtividade, potencialidades e limitações dos recursos naturais disponíveis.

Muito tem sido investido em estudos na Bacia do Rio Piracicaba porém estes referem-se mais a fornecer subsídios que orientem as ações necessárias à proteção, recuperação, conservação e utilização dos recursos hídricos da bacia. Apesar ser um dos objetivos do trabalho fornecer subsídios para o uso e ocupação do solo, este porém é apresentado em escala regional, não sendo abordada especificamente a área do município de Piracicaba, e sim a área da sub-bacia do rio Piracicaba, englobando os 
municipios de Americana, Analândia, Charqueada, Cordeirópolis, Corumbataí, Ipeúna, Iracemápolis, Limeira, Nova Odessa, Piracicaba, Rio Claro, Rio das Pedras, Santa Gertrudes, Santa Bárbara do Oeste, Santa Maria da Serra, São Pedro, Sumaré (SÃO PAULO, 1994).

Neste contexto há uma evidente carência de trabalhos que abordem o município de Piracicaba considerando a sua extensão total, enfatizando aspectos da adequação do uso das terras e o potencial para desenvolvimento agrícola no município.

\subsection{Exemplos internacionais}

$\mathrm{Na}$ Flórida foi realizado um planejamento na costa de St Lucie County utilizando para um estudo preliminar do uso das terras, a análise de fotografias aéreas comparando-as com o uso atual obtido por imagem TM/ LANDSAT 5. As informações obtidas foram processadas e integradas em um SIG, obtendo-se desta maneira as mudanças ocorridas no uso das terra. O conhecimento da dinâmica destas mudanças ocorridas no passado permite planejar a ocupação futura (DAVIDSON, 1992).

FAETH (1993) cita que em 1982 no estado de Wisconsin nos EUA, a assembleia legislativa preocupada com a constante degradação dos solos e recursos hídricos revisou a legislação para a conservação destes. A intenção da nova legislação era estabelecer normas e modelos de conservação de solos para a orientação da assistência técnica e coordenação dos esforços conservacionistas locais, estaduais e federais. Foram criados comitês municipais de conservação (LCCs) e um programa de controle da erosão bem como o encorajamento de outros municipios a executarem programas deste tipo. Para tanto, desenvolveu-se uma metodologia para a contabilidade dos recursos utilizados nos sistemas agrícolas, permitindo uma comparação econômica em diferentes condições de uso da terra. 
No municipio de Dane, no centro sul de Wisconsin, o LCC contou com a Pesquisa Universitária (Land Information and Computer Graphics Facility, School of Natural Resources, University of Wisconsin, Madison) para análise de dados e produção de um planejamento conservacionista. Este trabalho contou com uma estimativa de perda de terras por erosão, pela Equação Universal de Perda de Solo (USLE). Com a divisão das propriedades no município, uso da terra (imagem de LANDSAT/TM) e estimativa de perda de terras por erosão, foram feitos cálculos e mapeadas as áreas de maiores riscos de erosão do municipio (VENTURA et al., 1988).

Neste mesmo estado posteriormente, foi executada com os conservacionistas locais uma pesquisa sobre a visão destes sobre a implantação de SIGs, fatores que facilitavam e fatores que dificultavam a utilização destes no campo governamental. A resposta de todos foi unânime: que os órgãos oficias são os mais indicados para agrupar as informações do meio físico e processá-las em SIGs, e gerar informações para ajudálos a tomar decisões sobre o melhor uso e manejo conservacionista adeaquado às terras.

Pode-se esperar portanto que programas conservacionistas facilitem a ampla utilização dos SIGs no campo oficial, na medida em que criam demanda para suas capacidades. Os SIGs podem auxiliar nestes programas na medida em que combinam análises espaciais com habilidade de integrar dados rapidamente (VENTURA et al., 1993). 


\section{MATERIAL E MÉTODOS}

Considerando como escala de trabalho a microbacia hidrográfica SPAROVEK \& LEPSCH (1994) realizaram uma caracterização geral do município utilizando dados de solos (OLIVEIRA \& PRADO, 1989) e relevo (Cartas IBGE escala 1:50.000, folhas SF-23-M-III-1, SF-23-M-III-2, SF-23-M-III-3, SF-23-M-III-4 SF-23-M-IV-1, SF-23-YA-V-3), gerando mapas de classe de capacidade de uso (LEPSCH et al., 1991) por microbacias e em área total do município. Estes foram comparados com o uso das terras (imagens TM /LANDSAT 5, composição colorida bandas 3,4,5, 2/set de 1991, escala 1:100.000), obtendo-se um quadro da situação de ocupação em 1991.

Essas informações foram digitalizadas em forma de quadrícula sobre a área, utilizando-se uma malha amostral de de 250 metros x 250 metros, correspondendo a uma área de 6,25 ha.

Posteriormente estes dados foram analisados pelo o programa GMAP (SPAROVEK et al., 1993). Este é um programa de computador de análise de mapas geográficos que possibilita a digitalização de mapas temáticos (mapa de solos, declividade, uso da terra, divisões administrativas, etc.), fotografias aéreas ou imagens de satélite. Uma vez digitalizadas, essas informações podem ser quantificadas e cruzadas, possibilitando a obtenção de outros niveis de informação, como a classe de capacidade de uso, ou a adequação de uso da terra, em forma de tabelas ou localizadas em mapas. 
A área de estudos localiza-se entre as coordenadas $47^{\circ} 30^{\prime \prime}$ e $48^{\circ} 00^{\prime \prime}$ W e $22^{\circ} 30^{\prime \prime}$ e $23^{\circ} 00^{\prime \prime} \mathrm{S}$, estando contida na bacia do rio Piracicaba que correspondente a $12.400 \mathrm{~km}^{2}$, englobando parcialmente ou integralmente 50 municípios paulistas e 5 mineiros (PIRACICABA, 1991).

A área total de estudos ( $176.000 \mathrm{ha}$ ou $\left.1760 \mathrm{~km}^{2}\right)$, é um pouco maior que a área legal do município $\left(137.000 \mathrm{ha}\right.$ ou $\left.1372 \mathrm{~km}^{2}\right)$ pois as microbacias que possuíam apenas parte de sua área dentro dos limites deste, foram consideradas na sua totalidade, constituindo-se de 78 microbacias hidrográficas.

Segundo SPAROVEK \& LEPSCH (1994), na área predominam solos podzólicos e suas associações, num total de 81.950 ha $(47 \%)$. Os latossolos $(\mathrm{LE}+\mathrm{LR}+\mathrm{LV})$ ocupam 36.425 ha $(21 \%)$ situados predominantemente na parte oriental do municipio conforme Figura 1. 
Mapa pedológico simplificado das terras de Piracicaba (SP)

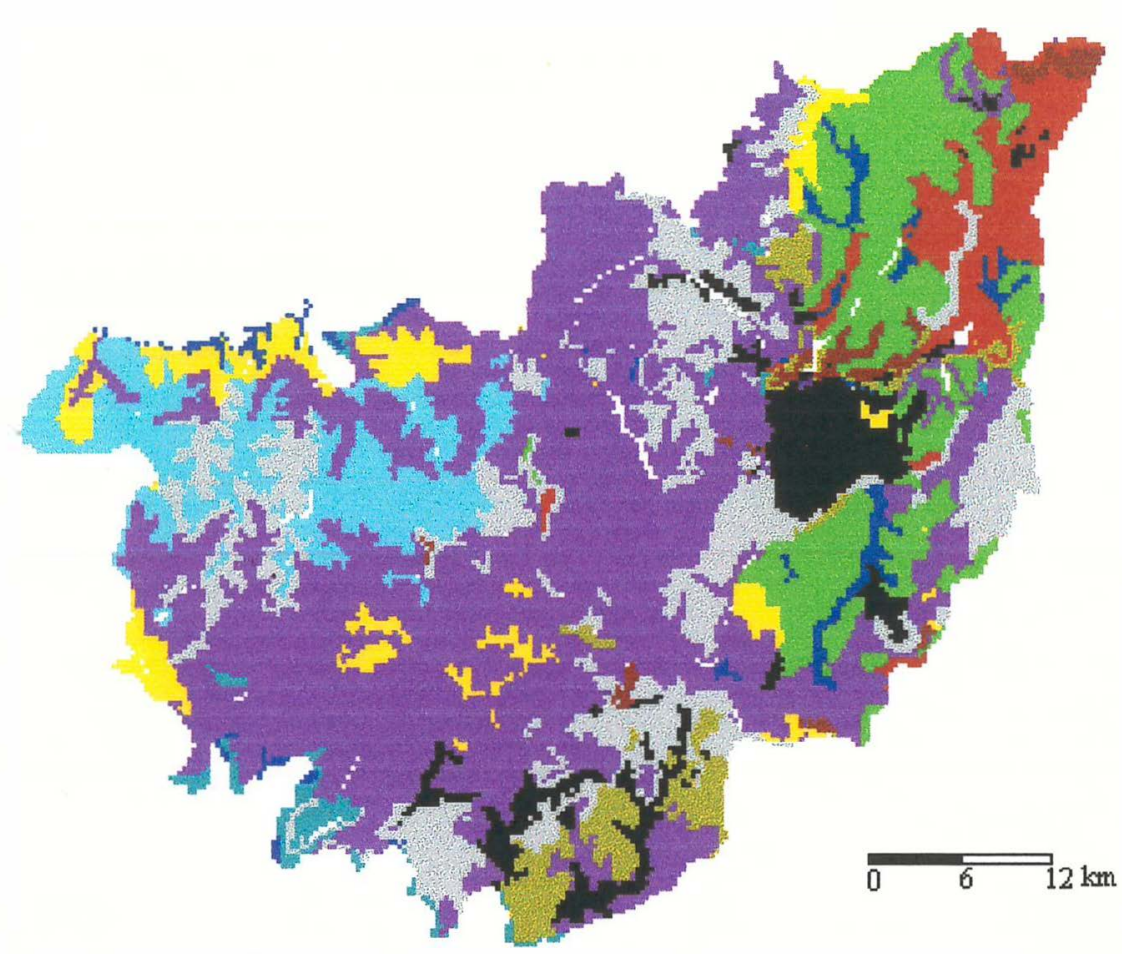

LR

LE

TE

PV

LV

$\mathrm{Li}$

PE 的喼

$\mathrm{AQ}$

G

$\mathrm{C}$

Outro solo

Fante:Adaptado e complementado do Otiveire e Predo, 1989

Figura 1: Mapa pedológico simplificado das terras de Piracicaba (SP)

Quanto a classe de declive a predominante é C, com 68.831 ha (39\%), os declives maiores (D+E) somam 64.293 ha (37\%) e os menores (A+B) somam 41.244 ha (23\%). A classe de capacidade de uso (LEPSCH et al., 1992) predominante é a IV, com $63.168(36 \%)$. As classes I, II, e III ocorrem em 71.938 ha (41\%) e as classes V, VI, VII, e VIII ocupam 34.032 ha (19\%).

Quanto ao uso das terras em 1991, as áreas ocupadas por cana-de-açúcar (86.819 ha) representam $49 \%$ do total, sendo que as áreas de pastagem (45.662 ha) representam $26 \%$. A área destinada a outras culturas situam-se ao redor de $5 \%$, e a área de vegetação natural ocupa aproximadamente $15 \%$. 
A comparação do uso em 1991 com a capacidade de uso indicou a adequação de uso, estando as áreas com uso adequado ao redor de $60 \%$, enquanto as áreas subutilizadas somaram ao redor de 7\%, e as áreas superutilizadas e utilizadas com risco ao redor de $27 \%$.

\subsection{Avaliação do potencial de utilização das terras}

A definição da utilização ideal das terras deve ser fundamentada nas características dos solos e do ambiente, bem como em aspectos estruturais e sociais.

A escolha dos parâmetros mais adequados que servirão para o agrupamento dos solos deve ser feita com base naqueles que exercem maior influência na utilização dos mesmos, principalmente os de natureza física, pois são de correção mais dificil que os de natureza química (FRANÇA, 1980).

Existem diversas condições que vão influenciar o uso da terra: tanto a nível local, como as restrições físicas e a fertilidade do solo, quanto a nível regional, como a cultura predominante na região, o traçado de estradas para escoamento de produção e outros. Para o presente estudo foram consideradas apenas as características do meio físico e a fertilidade do solo. Não foi possível ampliar o trabalho para condicionantes sociais pois neste contexto existem variáveis muito complexas que necessitam de um estudo aprofundado a parte para serem analisadas devidamente.

Partindo da base de dados existente (SPAROVEK \& LEPSCH, 1994) com uma visão geral sobre o uso das terras em Piracicaba e de dados analíticos inéditos, da carta pedológica semi detalhada do Estado de São Paulo folha de Piracicaba (OLIVEIRA \& PRADO, 1989), formecidos pela seção de pedologia do IAC, (Anexo 1) procedeu-se a determinação dos critérios para a adequação do uso das terras. 


\subsubsection{Erodibilidade}

O primeiro parâmetro analisado foi a erodibilidade do solo, ou seja, a sua sucetibilidade à erosão. Esta, segundo WISCHMEIER \& MANNERING (1969), é uma propriedade inerente ao solo, sendo um importante fator na previsão das perdas de terra por erosão. Porém, trata-se de uma propriedade complexa que depende da combinação de parâmetros individuais de cada solo, especialmente aqueles que determinam a velocidade de infiltração da água no perfil e aqueles que determinam a resistência à dispersão e ao arraste de partículas durante a chuva e o escorrimento superficial .

Para o cálculo da erodibilidade foi utilizado uma equação apresentada por DENARDIN (1990), que se baseia no nomograma de WISCHMEIER et al. (1971), como segue:

$$
\begin{aligned}
& \mathbf{K}=0,00000748(M)+0,00448059(P)-0,06311750(D M P)+0,01039567(R) \\
& \text { onde: } \\
& K=\text { valor estimado para o fator erodibilidade do solo, em (t. ha h/ ha Mj mm), } \\
& \mathbf{M}=\text { variável adimensional calculada a partir de parâmetros granulométricos, }
\end{aligned}
$$
ou seja: $\%$ novo silte $x(\%$ novo silte $+\%$ nova areia),

$\mathbf{P}=$ permeabilidade do solo conforme Wischmeier et al. (1971), no qual foram estabelecidas as seguintes classes de permeabilidade: $1=$ rápida; $2=$ moderada a rápida; $3=$ moderada $;=$ lenta $a$ moderada; $5=$ lenta $6=$ muito lenta,

DMP = diâmetro médio ponderado das partícula menores que $2 \mathrm{~mm}(\mathrm{~mm})$,

$\mathbf{R}=$ relação entre teor de matéria orgânica e o teor da nova areia (MO x \% nova areia)/100 
Este modelo foi testado em solos do Brasil e dos EUA, com valores de erodibilidades conhecidos através de determinação direta no campo. A exatidão da equação representada segundo DENARDIN (1990) pelo coeficiente de determinação de 0,9767 e erro padrão estimado de 0,006 t.ha.h/ha.Mj.mm (teste F), permite que ela substitua as determinações de campo na grande maioria dos casos.

Esta equação utiliza na sua maioria variáveis resultantes de análises de rotina, com exceção do parâmetro "M". Para o seu cálculo é necessário subdivisão da fração areia em areia muito fina, areia fina, areia média, areia grossa e areia muito grossa. Como na base de dados disponível estavam determinadas apenas as frações areia grossa e areia fina, a equação foi adaptada, substituindo-se novo silte $(0,002$ a $0,1 \mathrm{~mm})$ por silte $(0,002$ a $0,05 \mathrm{~mm})+$ areia fina $(0,05$ a $0,2 \mathrm{~mm})$ e a nova areia $(0,1$ a $2 \mathrm{~mm})$ por areia grossa $(>0,2 \mathrm{~mm})$.

Segundo WISCHMEIER et al.(1971), a erodibilidade tende a aumentar com o conteúdo de silte + areia muito fina e diminuir com os conteúdos de areia $>0,1 \mathrm{~mm}$, argila e Matéria orgânica. Desta maneira, ao se substituir na equação silte + areia muito fina (novo silte) por silte + areia fina, esta fração terá um pequeno acréssimo, fato que pode ser interessante para as presentes condições, pois a maioria dos solos tropicais apresentarem baixa porcentagem de silte e areia muito fina.

O diâmetro médio das partículas foi calculado por uma equação, descrita por BAVEL (1949), para diâmetro médio de agregados e aplicada neste caso para frações granulométricas.

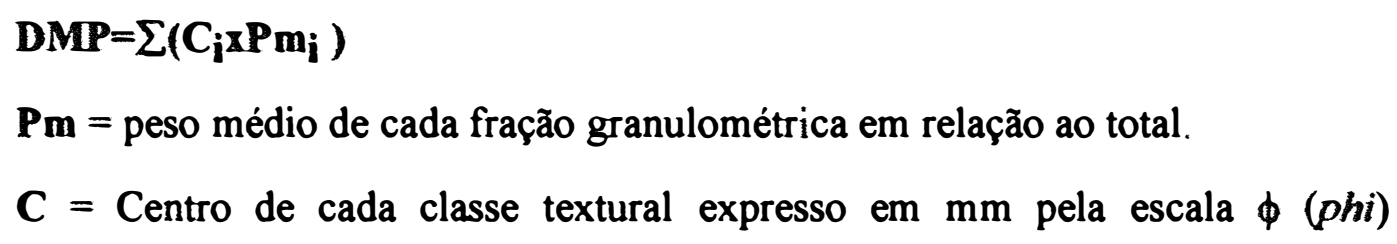


Tabela 1: Diâmetro médio de cada classe textural pela escala $P h i$

\begin{tabular}{cc}
\hline Classe Textural & $\begin{array}{c}\text { Diâmetro em mm } \\
\text { (escala Phi) }\end{array}$ \\
\hline Areia grossa & 0,65 \\
Areia fina & 0,150 \\
Silte & 0,0117 \\
Argila & 0,00024 \\
\hline \hline
\end{tabular}

A partir desta equação chegou-se a valores de $\mathrm{K}$, que foram classificados segundo a Tabela 2, apresentados por classes de solos no Anexo 2.

Tabela 2: Classificação do índice de erodibilidade (K).

\begin{tabular}{cc}
\hline $\begin{array}{c}\text { Classes de } \\
\text { Erodibilidade }\end{array}$ & K(t.ha.h/ha Mj.mm) \\
\hline alto & $>0,0318$ \\
médio & $0,0318-0,0247$ \\
baixo & $<0,0247$ \\
\hline
\end{tabular}

As classes foram definidas pela média mais ou menos vinte vezes a variância, obtendo-se valores próximos dos apresentados por BERTONI \& LOMBARDI NETO (1990), para algumas classes de mapeamento do Estado de São Paulo (PV 0,055 a 0,018 e LR 0,012 t. ha. h / ha Mj mm) e por CARVALHO et al. (1989) (PV 0,0232 tha h / ha Mj mm), e estão representadas na Figura 2. 

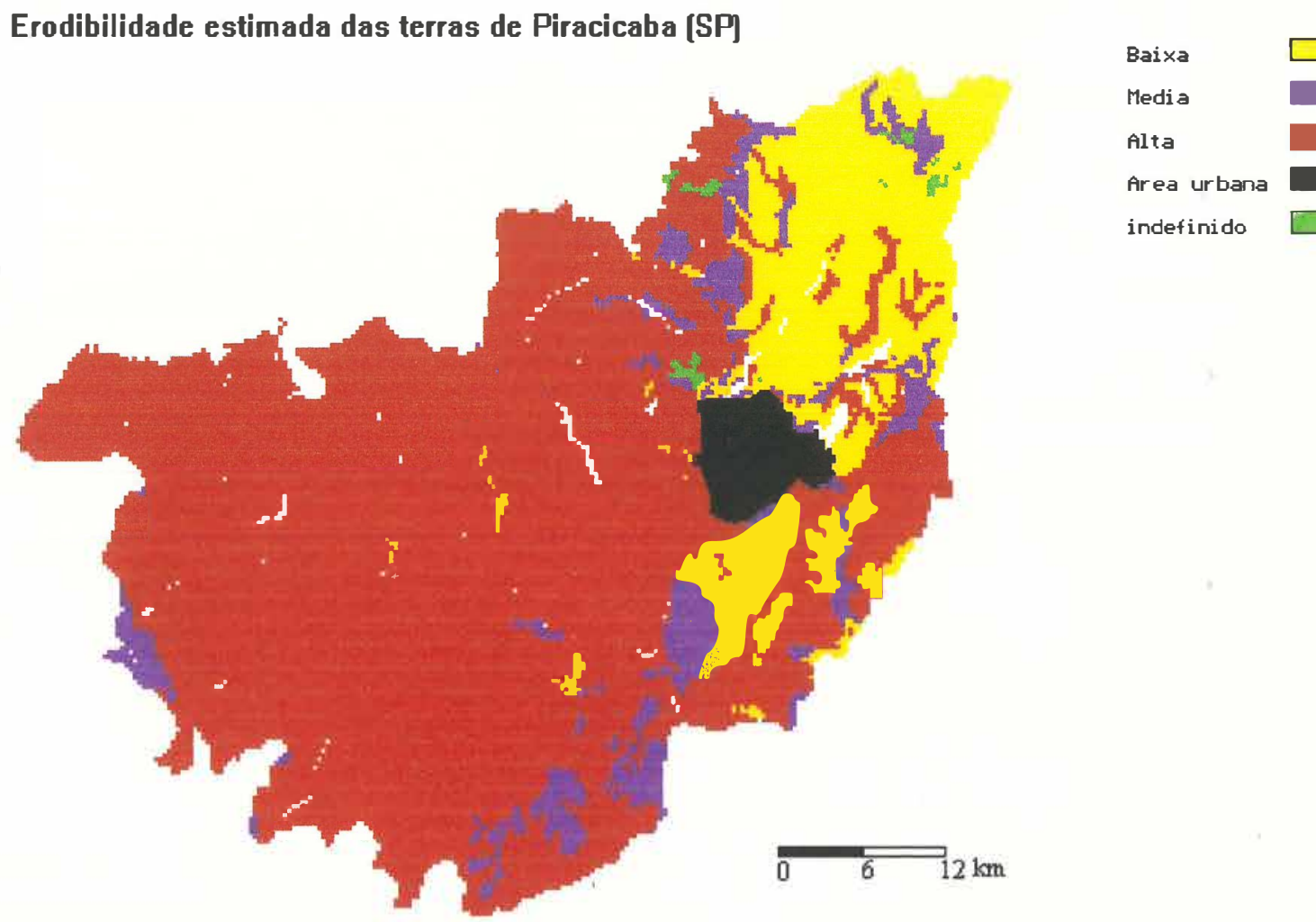

Figura 2: Erodibilidade estimada das terras de Piracicaba.

FOSTER et al. (1981) em trabalho sobre os solos dos EUA apresentaram valores para os EUA, classificando como baixa erodibilidade 0,01; moderada erodibilidade 0,03 e alta erodibilidade $0,06 \mathrm{t}$ ha $\mathrm{h} / \mathrm{ha} \mathrm{Mj} \mathrm{mm}$. Estes valores diferem daqueles encontrados para solos brasileiros por SILVA et al. (1993), classificando como baixa erodibilidade $(\mathrm{K})$ de 0,010 a $0,019 \mathrm{t}$ ha $\mathrm{h} / \mathrm{ha} \mathrm{Mj} \mathrm{mm}$ e alta $>0,020 \mathrm{t} \mathrm{ha} \mathrm{h} / \mathrm{h} \mathrm{Mj}$ $\mathrm{mm}$.

Outros autores como WISCHMEIER et al. (1969); FREIRE \& PESSOTI (1976); HENKLAN (1980); ANGULO (1983); BERTONI \& LOMBARDI NETO (1990); DENARDIN (1990); SILVA et al. (1993), observaram que a erodibilidade 
apresenta grande variação de valores, atribundo à enorme quantidade de variáveis condicionantes.

YOUNG et al. (1990) e JACOBS et al. (1995), descrevem a erodibilidade como uma propriedade dinâmica, apresentando variações durante as estações do ano. Estas variações estão correlacionadas a três fatores: temperatura, textura e quantidade de água anteriormente encontrada no solo. Como o valor de erodibilidade considerado normalmente é o valor médio anual, o efeito destes três fatores é mascarado.

Os valores estimados de erodibilidade através da equação de DENARDIN (1990) têm o objetivo de fornecer uma estimativa da erodibilidade média anual das unidades de mapeamento ocorrentes no município, não sendo consideradas portanto as possíveis variações sazonais.

\subsubsection{Espessura do solo}

A espessura do solo foi o outro parâmetro escolhido para ser relacionado com a erodibilidade dos solos para a avaliação do potencial de uso das terras.

Os solos foram classificados em delgados $(<0,5 \mathrm{~m})$, médios $(0,5$ a $1,00 \mathrm{~m})$, espessos (>1,00 m), identificados a partir da descrição das unidades de mapeamento.

A espessura do solo é uma variável importante na identificação do uso adequado das terras, pois se relaciona com a capacidade da cultura se estabelecer, com as práticas conservacionistas necessárias e com a reversibilidade dos efeitos da erosão.

LEPSCH et al. (1991) enfatizam que as propriedades do solo a serem julgadas para fins de determinação de suas limitações, são a profundidade efetiva, a capacidade de retenção de água, a permeabilidade e drenagem interna, a fertilidade e a possibilidade de motomecanização. Na sua maioria estas propriedades estão direta ou indiretamente relacionadas a espessura do solo. 
Segundo BERTONI \& LOMBARDI NETO (1990) o conhecimento da espessura da camada mais favorável ao desenvolvimento radicular e ao armazenamento da umidade disponível tem grande importância para o conhecimento da capacidade de uso do solo, determinando a cultura a ser instalada e a seleção das práticas conservacionistas.

\subsection{3 classe de declive}

A declividade foi classificada em A ( 0 a $2 \%$ ); B ( 2 a $5 \%$ ); C ( 5 a $10 \%$ ); D ( 10 a $15 \%$ ) e E ( > $15 \%$ ), e o mapa elaborado com base nas cartas planialtimétricas do IBGE, escala 1:50.000 em que o município estava contido.

A declividade, o comprimento e tipo de vertente são fatores que determinam a velocidade da enxurrada, relacionando-se diretamente com a intensidade do processo erosivo (SMITH \& WISCHMEIER, 1962 e WISCHMEIER \& SMITH, 1978), constituindo-se assim uma informação muito importante para o planejamento conservacionista.

A sobreposição do mapa de erodibilidade, espessura do solo e classe de declive, gerou o mapa de potencial de uso das terras de Piracicaba para cultura da cana-deaçúcar, levando em consideração o meio físico.

Foi definido como sendo de uso prioritário a lavoura de cana-de-açucar ná área pela abrangência em área cultivada e importância econômica. Com base nesta cultura o potencial foi dividido em cinco classes: Muito alto, Alto, Médio, Baixo e Muito baixo conforme critérios apresentados na Tabela 3. O mapa de potencial das terras de Piracicaba para a cultura da cana-de- açúcar está representado na Figura 3. 
Tabela 3: Critérios para avaliação do potencial de uso das terras de Piracicaba para a lavoura de cana-da-açúcar

\begin{tabular}{|c|c|c|c|}
\hline Erodibilidade & $\begin{array}{l}\text { Espessura } \\
\text { (m). }\end{array}$ & $\begin{array}{l}\text { Classe } \\
\text { declive }\end{array}$ & $\begin{array}{l}\text { Potencial uso para } \\
\text { cana-de-açúcar }\end{array}$ \\
\hline \multirow[t]{3}{*}{$\overline{\text { Alta }}$} & $>1,0$ & $\begin{array}{l}0-2 \% \\
2-5 \% \\
5-10 \% \\
10-15 \% \\
>15 \%\end{array}$ & $\begin{array}{l}\text { Alto } \\
\text { Alto } \\
\text { Médio } \\
\text { Baixo } \\
\text { Muito Baixo }\end{array}$ \\
\hline & $0,5-1$ & $\begin{array}{l}0-2 \% \\
2-5 \% \\
5-10 \% \\
10-15 \% \\
>15 \%\end{array}$ & $\begin{array}{l}\text { Alto } \\
\text { Médio } \\
\text { Baixo } \\
\text { Muito Baixo } \\
\text { Muito Baixo }\end{array}$ \\
\hline & $<0,5$ & $\begin{array}{l}0-2 \% \\
2-5 \% \\
5-10 \% \\
10-15 \% \\
>15 \%\end{array}$ & $\begin{array}{l}\text { Médio } \\
\text { Baixo } \\
\text { Muito Baixo } \\
\text { Muito Baixo } \\
\text { Muito Baixo }\end{array}$ \\
\hline \multirow[t]{2}{*}{ Média } & $>1,0$ & $\begin{array}{l}0-2 \% \\
2-5 \% \\
5-10 \% \\
10-15 \% \\
>15 \%\end{array}$ & $\begin{array}{l}\text { Muito Alto } \\
\text { Alto } \\
\text { Alto } \\
\text { Médio } \\
\text { Baixo } \\
\end{array}$ \\
\hline & $0,5-1$ & $\begin{array}{l}0-2 \% \\
2-5 \% \\
5-10 \% \\
10-15 \% \\
>15 \%\end{array}$ & $\begin{array}{l}\text { Alto } \\
\text { Alto } \\
\text { Médio } \\
\text { Baixo } \\
\text { Muito Baixo }\end{array}$ \\
\hline \multirow[t]{2}{*}{ Baixa } & $>1,0$ & $\begin{array}{l}0-2 \% \\
2-5 \% \\
5-10 \% \\
10-15 \% \\
>15 \% \\
\end{array}$ & $\begin{array}{l}\text { Muito Alto } \\
\text { Muito Alto } \\
\text { Alto } \\
\text { Médio } \\
\text { Baixo } \\
\end{array}$ \\
\hline & $0,5-1$ & $\begin{array}{l}0-2 \% \\
2-5 \% \\
5-10 \% \\
10-15 \% \\
>15 \%\end{array}$ & $\begin{array}{l}\text { Muito Alto } \\
\text { Alto } \\
\text { Médio } \\
\text { Baixo } \\
\text { Muito Baixo }\end{array}$ \\
\hline
\end{tabular}




\section{Potencial de uso das terras de Piracicaba para a cultura de cana-de-açúcar}

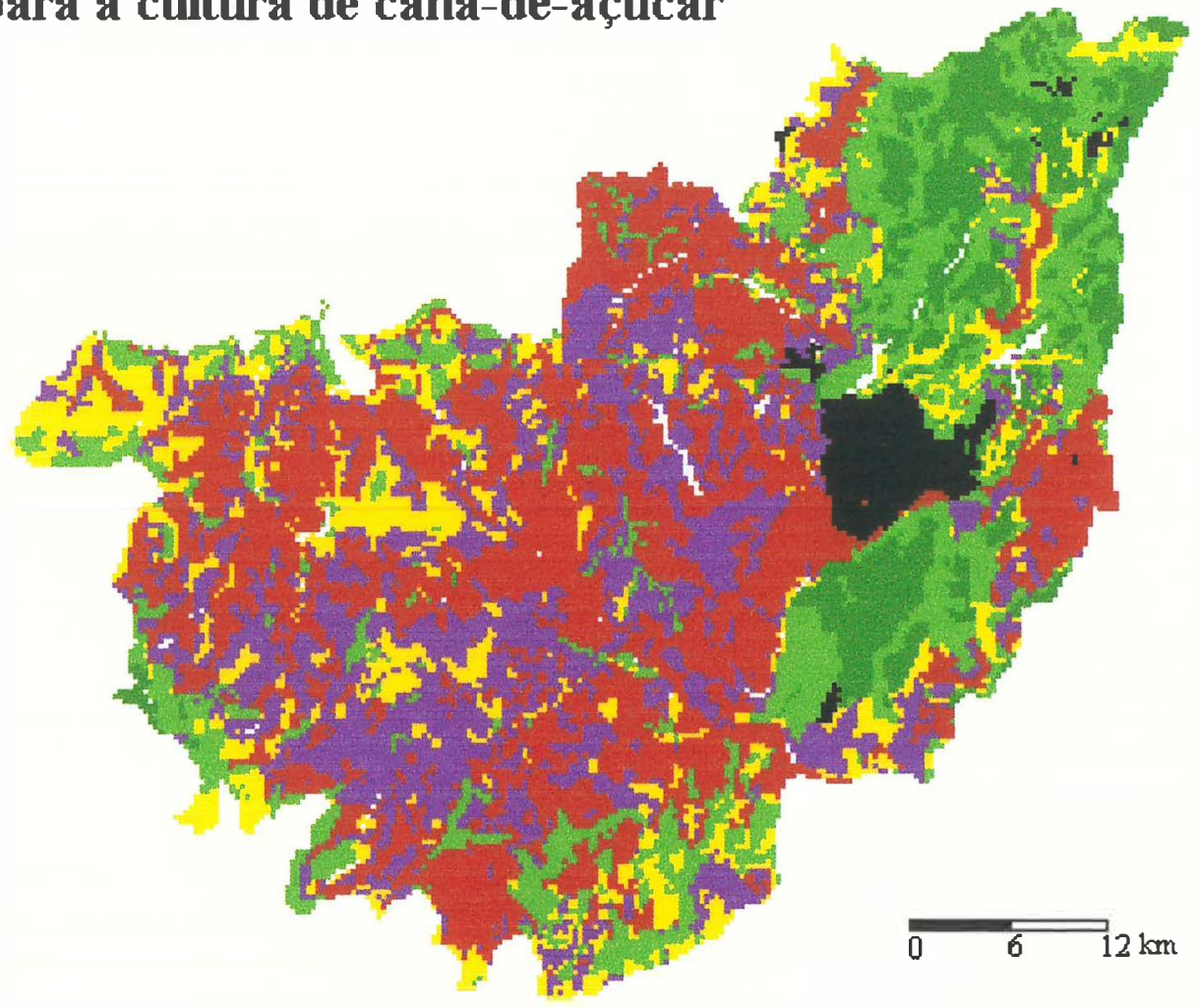

classes de potencial

Muito alta
Alta
Media
Baixa
Muito baixa
Urbana

Figura 3: Potencial de uso das terras de Piracicaba para a cultura da cana-deaçúcar

\subsection{Sistemas de manejo}

Dentro de cada classe de potencial de uso para a lavoura de cana-de-açúcar encontram-se várias classes de solos em distintas declividades. Estas foram listadas, quantificadas e agrupadas de acordo com o comportamento semelhante no que diz 
respeito às operações de manejo recomendado para implantação e manutenção da cultura da cana-de-açúcar.

À cada grupo deste foi atribuído um número e uma letra, correspondendo a um sistema de manejo próprio conforme representado na Tabela 4. Cada sistema de manejo foi caracterizado pelas principais operações envolvidas no processo produtivo para aquele determinado grupo de solos e classes de declive desde o plantio à colheita.

Tabela 4: Ocorrência das principais classes de solos agrupadas e o sistema de manejo correspondente para a cultura da cana de açúcar

\begin{tabular}{|c|c|c|c|}
\hline Potencial de utilizaça & Classe de solo & \% de ocorrência & Sistema de manejo \\
\hline \multirow[t]{3}{*}{ Muito alto } & $\begin{array}{l}\text { Latossolos eutróficos e } \\
\text { TE eutrófica }\end{array}$ & 5,8 & $1 \mathrm{a}$ \\
\hline & $\begin{array}{l}\text { Latossolos álicos, } \\
\text { distróficos }\end{array}$ & 3,2 & $1 \mathrm{~b}$ \\
\hline & Cambissolo álico & 0,3 & $1 \mathrm{~b}$ \\
\hline \multirow[t]{6}{*}{ Alto } & $\begin{array}{l}\text { Latossolos distrófico e } \\
\text { álicos }\end{array}$ & 6,1 & $2 \mathrm{a}$ \\
\hline & Areia quartz. álica & 1 & $2 \mathrm{a}$ \\
\hline & $\begin{array}{l}\text { Latossolos e TE } \\
\text { eutróficos }\end{array}$ & 2,6 & $2 b$ \\
\hline & PVs álicos e distróficos & 7,5 & $3 \mathrm{a}$ \\
\hline & Cambissolo distrófico & 0,6 & $3 a$ \\
\hline & Gleys distróficos & 1,8 & $4 a$ \\
\hline \multirow[t]{4}{*}{ Médio } & $\begin{array}{l}\text { Latossolos álicos } \\
\text { distroficos }\end{array}$ & 3,2 & $5 a$ \\
\hline & LE e TR eutróficos & 2,2 & $5 \mathrm{~b}$ \\
\hline & PV álico abrupto & 5,4 & $6 a$ \\
\hline & Areia quartz. álica & 3,7 & $7 \mathrm{a}$ \\
\hline \multirow[t]{5}{*}{ Baixo } & Latossolos distrófico & 1,3 & $8 \mathrm{a}$ \\
\hline & PVs álicos abruptos & 17,8 & $8 \mathbf{a}$ \\
\hline & Areia quartz. álica & 2,4 & $9 \mathrm{a}$ \\
\hline & Litólico distrófico & 0,9 & $10 \mathrm{a}$ \\
\hline & PE + Li eutófico & 0,3 & $10 \mathrm{~b}$ \\
\hline \multirow[t]{5}{*}{ Muito Baixo } & $\begin{array}{l}\text { Latossolo e Areia } \\
\text { quartz. álica }\end{array}$ & 0,8 & $11 \mathrm{a}$ \\
\hline & PVs eutrófico abrupto & 1,5 & $12 \mathrm{a}$ \\
\hline & $\begin{array}{l}\text { PVs distróficos e álicos } \\
\text { abruptos }\end{array}$ & 15,3 & $12 \mathrm{~b}$ \\
\hline & Litólicos eutróficos & 5,9 & $13 \mathrm{a}$ \\
\hline & Litólicos distróficos & 9 & $13 \mathrm{~b}$ \\
\hline
\end{tabular}


Baseado nos trabalhos de ZAMBELLO Jr et al. (1983), COLETI (1987), FREITAS (1987), PERTICARRIARI \& IDE (1988), MARGARIDO et al. (1988) e JOAQUTM et al. (1994 a e b), entrevista com técnicos das Usinas Costa Pinto SA, Usina Santa Helena e Usina Quatá, planilhas do Depto. Agronômico da Associação dos Fornecedores de cana de Piracicaba e da ORPLANA (Organização dos plantadores de Cana-de-açúcar) as operações correspondentes a cada sistema de manejo foram detalhadas de forma a representarem todo o processo produtivo de cada Sistema de manejo, desde o preparo do solo até a colheita (Anexo 3 ).

\subsubsection{Detalhamento das operações}

Em cada sistema de manejo foram detalhadas, de acordo como as características do grupo de solos correspondente, as operações, como a construção de carreadores, erradicação da soqueira, preparo e correção do solo, tratos culturais, e colheita.

O manejo adotado em cada sistema tem o objetivo de maximizar o potencial produtivo da cana-de-açúcar naquelas condições sem contudo promover o esgotamento dos solos ou favorecer o processo erosivo.

Desta forma, as operaçð̃es escolhidas buscaram representar um sistema de produção ideal, procurando representar uma forma de condução da cana-de-açúcar com minimização dos impactos ambientais.

Apesar do detalhamento das operações em cada sistema de produção foram necessárias algumas simplificações, porém como os sistemas foram comparados entre si 
estas simplificações não representaram perda de compreensão do processo como um todo.

A prática de adubação orgânica como aplicação de vinhaça ou torta de filtro embora sendo reconhecidamente uma prática de ampla difusão na região com resultados comprovadamente positivos no que diz respeito ao aumento de produtividade (JOAQUIM et al.,1994 a e b) podendo substituir em parte a adubação mineral (PENATI et al., 1988) não foi incluída. Esta operação envolve um manejo mais específico relacionado a dose a ser aplicada, fertilidade do solo, proximidade das Usinas e equipamentos para aplicação, o que restringe a área de aplicação, não podendo ser considerada uma prática possível de ser adotada em área total.

\subsubsection{Produtividade}

A produtividade da cana-de-açucar está diretamente relacionada ao clima, sendo este o seu fator determinante (OMETO, 1981; IDE \& BLANCHI, 1984; BARBIERI, 1993 e BEAUCLAIR, 1994).

NUNES (1992), associando médias de produtividade de cana-de-açúcar na região de Piracicaba em quatro cortes às variedades plantadas em solos fracos, solos médios e solos bons, encontrou variações de 69 a 98 tha. COOPERSUCAR (1982) elacionando médias de produtividade à classes de solos na região de Piracicaba para a safra 80/81 apresenta valores como 92 tha para Terra Roxa Estruturada, 67 tha para Latossolo Vermelho Amarelo e 87 tha para Latossolo Vermelho Escuro, sem contudo especificar o corte a que se referem tais valores.

Dentro deste contexto foi elaborado um método para estimativa da produtividade da cana-de-açúcar para as unidades de mapeamento dos solos do municipio. Foi considerada na estimativa o componente climático da produtividade, o 
componente fertilidade do solo e o componente ambiente físico para o desenvolvimento radicular (espessura e disponibilidade da água no solo).

Como a área de estudos encontra-se em uma única região climática (BARBIERI, 1993) a participação do clima na produtividade foi considerada constante.

Para representar a produtividade média em cinco cortes, foi considerado o valor máximo de 90 tha ano. Existem trabalhos com resultados de produtividade média na região associados a variedades e classes de solos (JOAQUIM et al.,1994 a) com médias superiores a este valor, porém considerando apenas quatro cortes. Assim, como o número de cortes tem valor depressivo sobre a produtividade (BEAUCLAIR, 1994), adotou-se o valor de $90 \mathrm{t} / \mathrm{ha}$ ano como média ideal em cinco cortes.

\subsubsection{Cálculo da produtividade}

Atribuiu-se ao clima uma participação em produtividade constante de $60 \mathrm{t} / \mathrm{ha}$, correspondendo a $67 \%$ do valor máximo. 0 restante 30 t/ha ( $33 \%$ do valor máximo), variou de acordo com a avaliação dos outros parâmetros (fertilidade, espessura do solo e disponibilidade de água no solo)

Para a fertilidade considerou-se os níveis de Potássio ( $\mathrm{K}$ meq/100g), a Capacidade de Troca de Cátions (T), e a Saturação por Bases (V \%), que segundo BITTENCOURT et al. (1989) e BITTENCOURT et al. (1990), estão associados a produtividade da cana-de-açúcar.

Dentro do componente que envolve atributos para o bom desenvolvimento das plantas, incluiu-se a espessura do solo e a disponibilidade de água do solo.

A avaliação dos atributos relacionados à fertilidade foi feita sobre os dados analíticos das unidades de mapeamento do município seguindo os critérios relacionados 
na Tabela 5, em função do grau de limitação, baseado em trabalhos de PENNATI et al. (1988) e BITTENCOURT et al. (1990).

Tabela 5: Atributos do solo relacionados a sua fertilidade em função do grau de limitação à produtividade da cana-de-açúcar

\begin{tabular}{cc}
\hline Atributo & Grau de limitação \\
\hline $\mathrm{K}(\mathrm{meq} / 100 \mathrm{~g})<0,35$ & limitante \\
$\mathrm{K}(\mathrm{meq} / 100 \mathrm{~g})>0,35$ & não limitante \\
$\mathrm{T}(\mathrm{meq} / 100 \mathrm{~g})<7,5$ & limitante \\
$\mathrm{T}(\mathrm{meq} / 100 \mathrm{~g})>7,5$ & não limitante \\
$\mathrm{V} \%<50$ & limitante \\
$\mathrm{V} \%>50$ & não limitante \\
\hline
\end{tabular}

Estes limites dos valores adotados para o componente fertilidade são valores médios encontrados em trabalhos que relacionam níveis de produtividade à alguns destes atributos (PENNATI et al., 1988 e BITTENCOURT et al., 1990). Acima desses valores, o que foi chamado de não limitante, espera-se uma produtividade ideal, desde que satisfeitas todas as outras necessidades da cultura da cana-de-açúcar e dentro dos limites esperados para s variedade utilizada.

Para o cálculo final do componente fertilidade do solo foi atribuído um valor a este grau de limitação, variando de zero a dois. Caso não ocorresse nenhum fator limitante foi atribuído valor dois, caso ocorresse um ou dois fatores limitantes foi atribuído valor um, e caso todos os fatores fossem limitantes considerou-se valor zero, de acordo com a Tabela 6: 
Tabela 6: Valor atribuído ao grau de limitação do componente fertilidade

\begin{tabular}{cc}
\hline $\begin{array}{c}\text { Ocorrência de fator } \\
\text { limitante }\end{array}$ & valor \\
\hline nenhuma & 2 \\
uma ou duas & 1 \\
três & 0 \\
\hline \hline
\end{tabular}

$\mathrm{Na}$ avaliação da espessura do solo foi atribuído valor zero para solos delgados (0 a $50 \mathrm{~cm}$ ), valor um para solos médios $(50$ a $100 \mathrm{~cm}$ ) e valor dois para solos espessos $(>100 \mathrm{~cm})$, conforme Tabela 7.

Tabela 7: Valor atribuído à avaliação da espessura do solo

\begin{tabular}{cc}
\hline Espessura do solo & Valor atribuído \\
\hline$>100 \mathrm{~cm}$ & 2 \\
$50 \mathrm{a} 100 \mathrm{~cm}$ & 1 \\
$<50 \mathrm{~cm}$ & 0 \\
\hline
\end{tabular}

$\mathrm{Na}$ avaliação da disponibilidade hídrica considerou-se valor zero para solos com baixa disponibilidade hídrica como AQ, Aluviais e Litólicos, valor um para solos com média disponibilidade hídrica como Latossolos e PVs de textura média e valor dois para solos com alta disponibilidade hídrica como Latossolos argilosos ou PVs abruptos, conforme Tabela 8:

Tabela 8: Valor atribuído à avaliação da disponibilidade hídrica

\begin{tabular}{cc}
\hline Disponibilidade hídrica & Valor \\
\hline Alta & 2 \\
Média & 1 \\
Baixa & 0 \\
\hline
\end{tabular}


Somando-se estes três valores (componente fertilidade, espessura do solo e disponibilidade hídrica) e multiplicando-se por 5 chegou-se ao valor do incremento de produtividade média relativo a estes fatores, podendo variar de 0 a 30 tha, conforme observa-se no Anexo 4.

Para cada sistema de manejo a estimativa da produtividade média foi feita ponderando-se a produtividade estimada da unidade de mapeamento presente no sistema por sua porcentagem de ocorrência dentro deste.

Utilizou-se uma produtividade média por ano igual para os cinco cortes. Considerando que a variação da produtividade a cada corte é extremamente dependente da relação entre variedades e fertilidade do solo (NUNES, 1992) e considerando uma única variedade é função de sua constituição genética (efeito genotípico), do conjunto de condições externas que afetam o seu crescimento e desenvolvimento (efeito ambiente), e da interação entre esses dois efeitos (BRAGA 1994) não seria possível estimar a produtividade esperada de cada corte para todas as unidades de mapeamento do município pois tem-se um número muito grande de interações impossível de serem relacionadas e o banco de dados disponível é limitado.

\subsubsection{Cálculo do custo das operaçōes}

O custo das operações foi calculado baseado no rendimento operacional médio de cada conjunto trator-implemento segundo MARGARIDO et al. (1988). Considerouse os valores de hora máquina publicados pelo Instituto de Economia Agrícola (IEA, 1995). Foi necessário um detalhamento dos sistemas de manejo especificando as operações e o custo dessas para diferenciação do custo total de cada sistema de manejo de modo a ser possivel uma comparação entre eles. 
Para alguns casos foram considerados custos médios fornecidos pela Associação dos Fornecedores de cana de Piracicaba e pela ORPLANA (Organização dos plantadores de cana), e/ou trabalhos publicados contendo avaliaçōes econômicas de sistemas de produção de cana-de-açúcar. Esses valores encontram-se detalhados no Anexo 5.

\subsubsection{Cálculo da produção e custo total para cada sistema de manejo}

Para o cálculo da produção total de cada sistema de manejo para a cana-deaçúcar considerou-se cinco cortes da cana-de-açúcar: 1 corte de cana-planta e 4 cortes de cana-soca. Existem trabalhos que indicam a possibilidade de até oito cortes na região de Piracicaba, porém em condições específicas extremamente favoráveis. Para o presente estudo, adotou-se para o cálculo do ciclo produtivo total 5 cortes, baseado em uma média de estágio de reforma de 24 usinas cooperadas da Copersucar de 5,3 cortes (JOAQUIM et al., 1994 b).

Para os tratos culturais foi adotada uma seqüência de operações única para todos os sistemas de manejo. Para o sistema de colheita também foi adotada uma só sequência de operações porém uma etapa do sistema que é o corte é função da produtividade do sistema, variando entre os sistemas de manejo (Anexo 5). Deste modo, para o cálculo das despasas totais de cada sistema de manejo, foram somados os custos do plantio da cana-de-açúcar mais cinco vezes os custos dos tratos culturais (1 cana planta +4 canas socas) e cinco vezes os custos da colheita. Posteriormente dividiu-se o total por cinco (cinco safras) e obteve-se o total de despesas por ha ano para as áreas em produção. 
Para o cálculo de produção total multiplicou-se a produtividade média de cada sistema de manejo por cinco safras. Multiplicando-se a produção total pelo valor da tonelada de cana-de-açúcar recebida pelo produtor em junho de 1995 (U\$ 11,5), obtevese a receita total e subtraindo-se desta as despesas totais obteve-se a margem bruta nas cinco safras, e posteriormente dividindo-se por cinco obteve-se o margem bruta total em U\$/ha.ano para as áreas em produção em cada sistema de manejo.

\subsection{Modelagem dos cenários:}

Com base nas classes de potencial para a cultura da cana-de-açúcar foram simulados cinco cenários. Em cada cenário foi testado um nível crescente de ocupação das terras como segue:

Cenário 1: cana-de-açúcar até potencial Muito Alto.

Cenário 2:cana-de-açúcar até potencial Alto

Cenário 3 :cana-de-açúcar até potencial Médio

Cenário 4:cana-de-açúcar até potencial Baixo

Cenário 5:cana-de-açúcar até potencial Muito Baixo

Cada Cenário é representado pelos Sistemas de manejo descritos na Tabela 4, que estão contidos nas classes de potencial a serem ocupadas no cenário correspondente. 
Estes cenários estão representados na figura 4 :
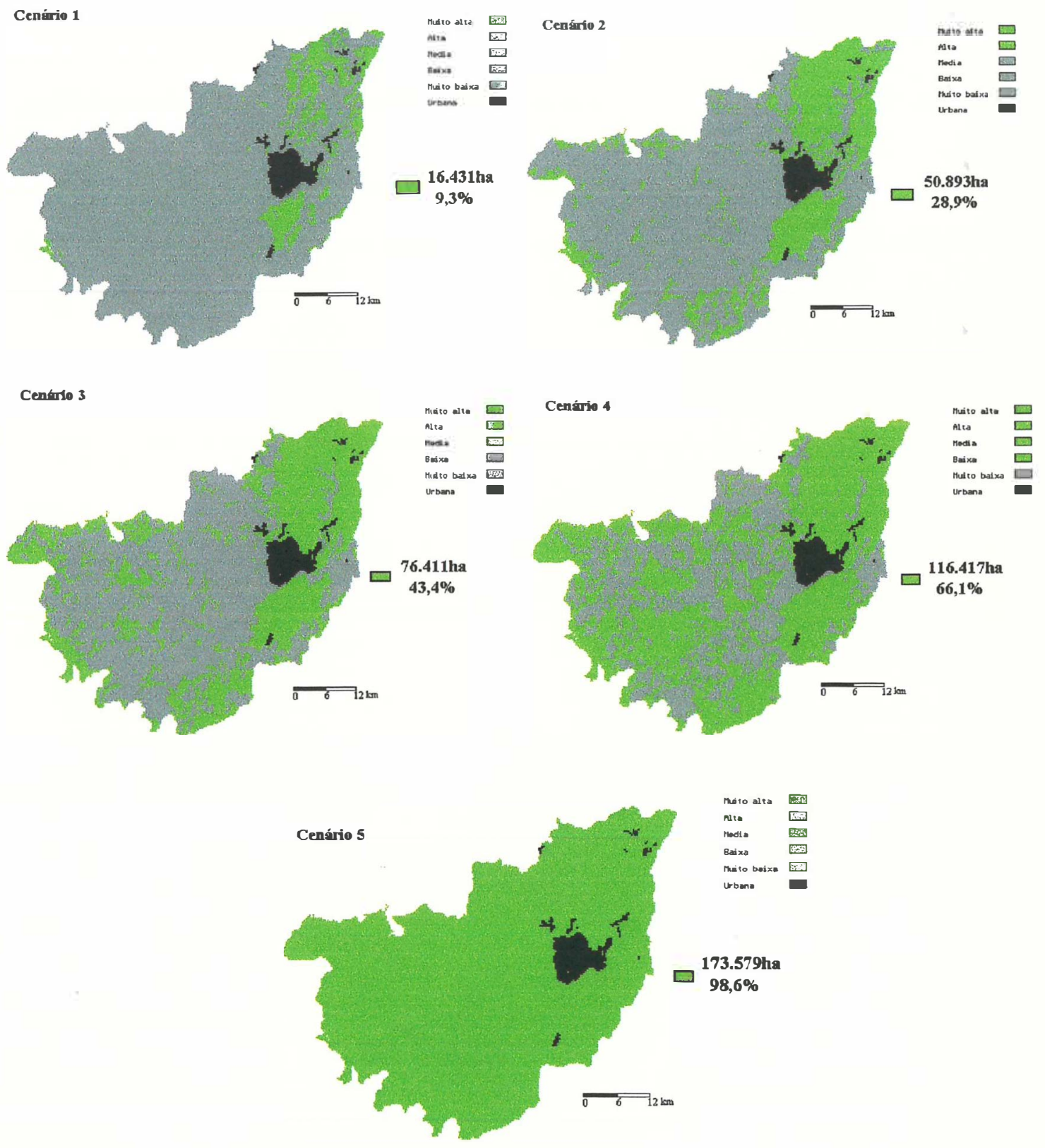

Figura 4: Cenários de ocupação crescente com cana-de-açúcar nas terras de Piracicaba. 


\subsubsection{Avaliaçåo dos Cenários}

Cada cenário é composto de um conjunto de Sistemas de manejo de acordo com a Tabela 4.

A avaliação de cada cenário foi baseada na produção total em t/ano, na margem bruta total em U\$/ano, na receita total em US/ano e na margem bruta total em U\$/ha ano. Através destes índices os cenários foram comparados e avaliados. 


\section{RESULTADOS E DISCUSSÃO}

\subsection{Avaliação econômica}

Em cada cenário foi calculada a área total, a área em produção, a produtividade total em $1000 \mathrm{t}$, a margem bruta total em U\$ por área em produção e a margem bruta em U\$ por ha total por ano (Anexo 7).

Considerando os sistemas descritos no Anexo 3, e um sistema de produção efetivamente instalado, a área em produção real é variável entre os sistemas de manejo de acordo com o ciclo da cana-de-açúcar recomendada para a área em questão.

Para cada área foi adotado um sistema de produção de modo a aproveitar ao máximo o potencial produtivo da referida área considerando um sistema sustentável. Dentro destes sistemas adotou-se para as áreas com potencial elevado para a cana-deaçúcar o plantio de cana de ano, o que permite uma produção contínua na área. Porém a época de plantio é de alto risco de erosão devido a ocorrência de chuvas intensas (setembro a dezembro). Como essas áreas de elevado potencial para cana-de-açúcar provavelmente estão menos sujeitas ao processo erosivo, a produção contínua nessas terras não deve implicar em elevado risco de degradação, desde que feito o manejo conservacionista adequado. Apesar da cana de ano apresentar uma produtividade média em todo o ciclo produtivo mais baixa, esta é compensada pela produção contínua na área, permiitindo todo ano uma safra, mesmo nos períodos de reforma. 
Para as áreas com potencial um pouco menor foi recomendado o plantio de cana de ano e meio, em alguns caso com rotação com adubação verde no verão utilizando a crotalária (Crotalaria juncea). Nesse caso, a época de plantio coincide com épocas de menor ocorrência de chuvas intensas (março a maio), diminuindo os riscos de erosão no período antes e depois do plantio, quando o solo fica mais exposto. Apesar de a cana de ano e meio ser mais produtiva em termos de média total do ciclo produtivo, no sistema de produção adotado existe um ano em que não há colheita. Deste de modo, a produtividade média de cinco safras é dividida por seis anos, igualando-se portanto à produtividade média da cana de ano.

Nas áreas com potencial muito baixo foi recomendado o plantio de cana de ano no inverno (adotou-se a denominação de cana de inverno), para fugir totalmente do plantio no período chuvoso. Nas áreas onde propõe-se este sistema ocorrem solos rasos ou muito sujeitos à erosão, sendo desejável o plantio em época sem chuvas, utilizando irrigação. Inclue-se para esses sistemas um ano no ciclo produtivo. Neste ano, a área estaria com adubação verde com crotalária (Crotalaria juncea) no verão deixando-se os restos culturais sobre a superfície. Por serem solos rasos não se recomenda uma produção contínua, admitindo-se que neste período de pousio a leguminosa estará contribuindo para a incorporação de certa quantidade de Nitrogênio devido a fixação desse pelas bactérias associadas às raízes da leguminosa.

\subsubsection{Cálculo da área em produção}

Para os sistemas onde está sendo recomendada a cana de ano, em um sistema planejado, tem-se na área total ao mesmo tempo cinco diferentes estágios do processo produtivo: áreas em quinto corte, reformas e plantio; áreas em primeiro corte; áreas em 
segundo corte; áreas em terceiro corte e áreas em quarto corte. Para estes casos a área total é igual a área em produção efetiva.

Para as áreas onde está sendo recomendada a cana de ano e meio, de maneira análoga, tem-se neste caso ao mesmo tempo na área total em um sistema de produção planejado seis etapas do processo produtivo: áreas em reforma com plantio de adubação verde (crotalária - Crotalaria juncea) ou não durante o verão e plantio; áreas em primeiro corte; áreas em segundo corte; áreas em terceiro corte; áreas em quarto corte e áreas em quinto corte. Nestes casos foi considerada como área de produção efetiva 5/6 da área total e a produção total por ano foi calculada baseada nesta área de produção efetiva.

Para os sistemas onde estará sendo proposta a cana de inverno (cana de ano a ser plantada no inverno), o sistema de produção prevê também 6 estágios: áreas em quinto corte e rotação com adubação verde (Crotalaria juncea) durante o verão; áreas em reforma e plantio; áreas em primeiro corte; áreas em segundo corte; áreas em terceiro corte e áreas em quarto corte. Da mesma forma como para as áreas com cana de ano e meio foi considerada como área de produção efetiva $5 / 6$ da área total e a produção total por ano foi calculada baseada nesta área de produção efetiva.

Para os três casos a margem bruta total foi calculada sobre a produção total e a margem bruta em U\$/ha ano foi calculada sobre a área total, dividindo a margem bruta total pela área total. Inclue-se portanto no cálculo da margem bruta por ha ano as áreas que não estão efetivamente produzindo. 


\subsection{Sistemas de manejo}

Inicialmente foram observadas as tendências gerais dos sistemas de manejo.

\subsection{1 Área total e área em produção}

Conforme o sistema de manejo adequa-se às situações de maior risco, a área efetiva de produção diminue. Nos sistemas onde está proposto a plantio da cana de ano continuamente a área em produção é igual a área total. Porém nos sistemas onde está proposto o plantio de cana de ano e meio e cana no inverno a área sob produção efetiva é proporcionalmente menor que as áreas de plantio de cana de ano como pode ser observado no gráfico 1 :

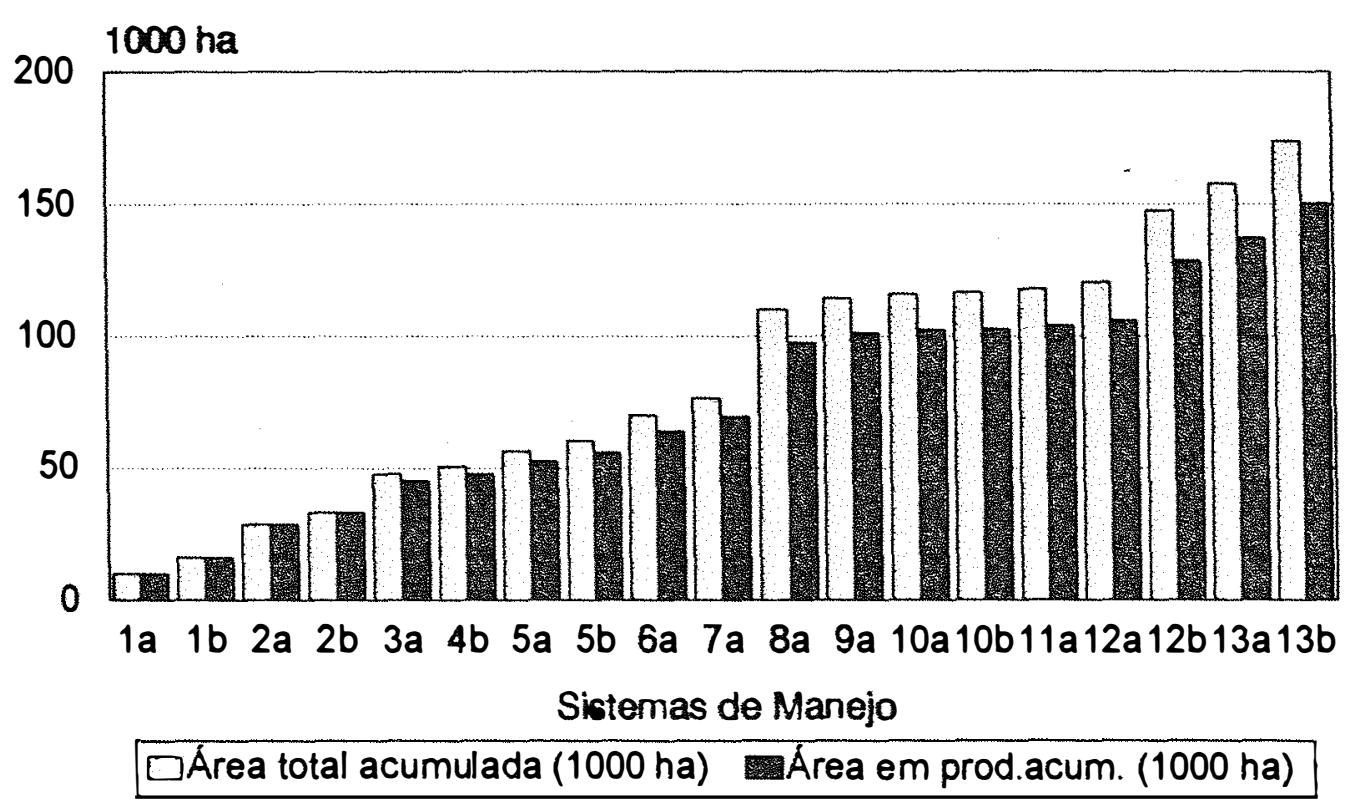

Gráfico 1: Área total e área em produção efetiva 
Conseqüentemente nestas áreas com cana de ano e meio e cana de inverno (sistemas 3a a 13b) a margem bruta por ha total por ano é proporcionalmente menor, pois a margem bruta total das áreas em produção efetiva ( $5 / 6$ do total da área), estará sendo dividida pela área total.

\subsubsection{Margem bruta}

Cada sistema de manejo possue uma margem bnuta por ha total por ano. Observou-se que a tendência desta é diminuir conforme propõe-se a ocupação de áreas com menor potencial para a cultura da cana-de-açúcar, conforme pode ser observado no gráfico 2:

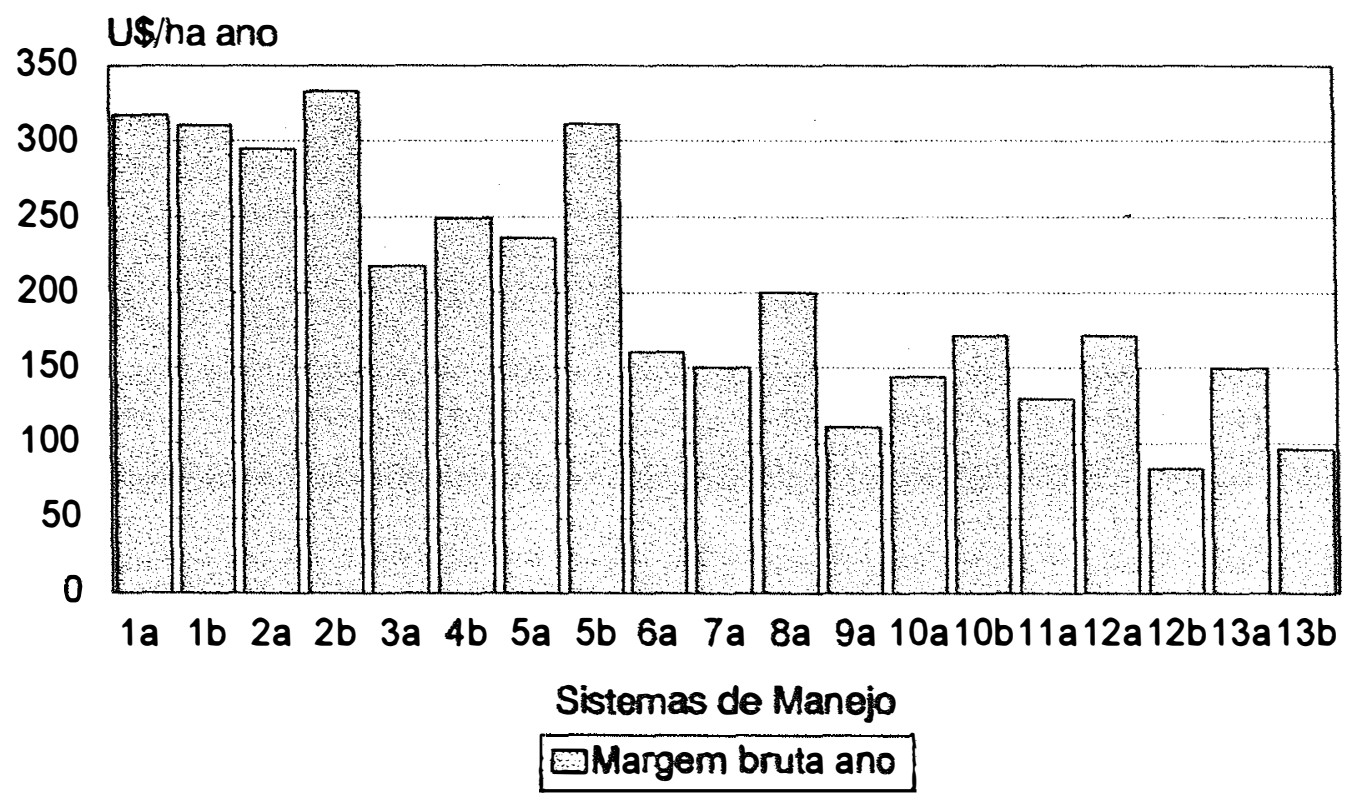

Gráfico 2: Margem bruta relativa aos sistemas de manejo por ha total/ano

Esta tendência é explicada pelo fato de conforme o potencial das terras para o cultivo da cana-de-açúcar diminue, as despesas referentes a cada sistema de manejo aumentam. Esse aumento deve-se principalmente às operaçðes para a implantação da 
cultura, pois para controlar o processo erosivo que pode vir a ocorrer no plantio e estabelecimento da cultura, são adotadas práticas conservacionistas mais intensas aumentando as despesas do sistema, conforme observa-se no gráfico 3.

Subentende-se que nestas áreas com potencial menor para o plantio da cana-deaçúcar o risco de erosão é maior e por isso são necessárias essas práticas.

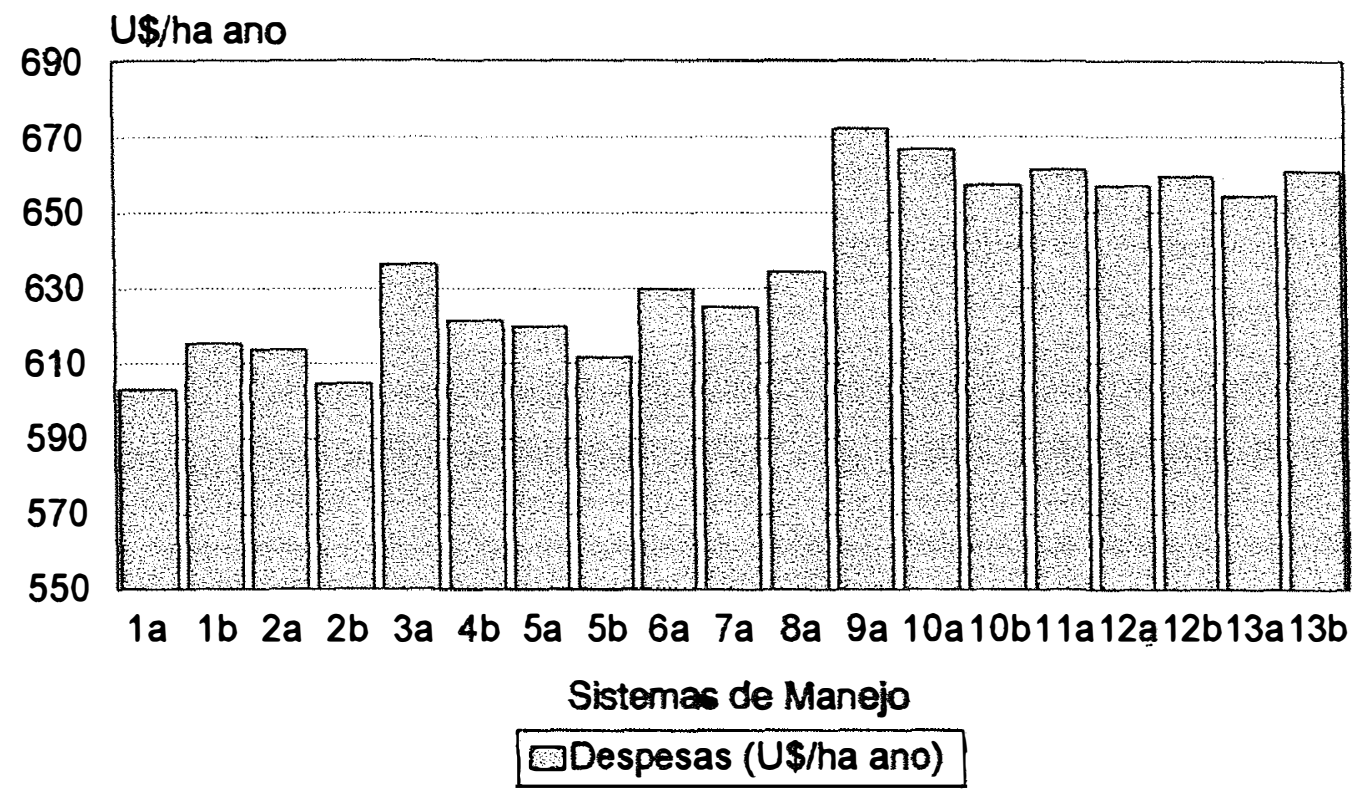

Gráfico 3: Despesas relativas aos sistemas de manejo em U\$ por ha por ano

Observa-se também que a margem bruta por hà total diminue, pois conforme ocupam-se áreas com menor potencial e aumentam as despesas, a receita mantém-se constante ou até diminue, pois esta é função da produtividade média por ha.

A produtividade estimada conforme metodologia descrita anteriormente, é uma média das unidades de mapeamento ocorrentes em cada sistema de manejo ponderada pela área de ocorrência destas no referido sistema. Para as classes de menor potencial de utilização para a cana-de-açúcar, a produtividade média apresentou-se geralmente menor, por atributos das próprias unidades de mapeamento ocorrentes nestas classes, refletindo ainda mais em diminuição da receita por ha ano dos sistemas de manejo. 
Existem alguns sistemas de manejo como por exemplo o 5b que apesar de ter um potencial de utilização para a cana-de-açúcar classificado como médio, possue uma alta margem bruta em relação aos outros sistemas conforme observa-se no gráfico 2 . Isto se deve ao fato dos solos ocorrentes neste sistema especificamente serem solos com características que segundo a metodologia proposta apresentam uma alta produtividade estimada.

Observou-se também que a tendência de decréssimo da margem bruta em relação aos sistemas de manejo não é linear, conforme indicado no gráfico 2. Isso é explicado pelo fato de cada sistema de manejo apresentar diferentes custos de implantação e manutenção da cultura da cana-de-açúcar bem como diferenças, não necessáriamente decrescentes por sistemas de manejo, na receita e consequentemente margem bruta por ha ano, conforme observa-se no Gráfico 4 .

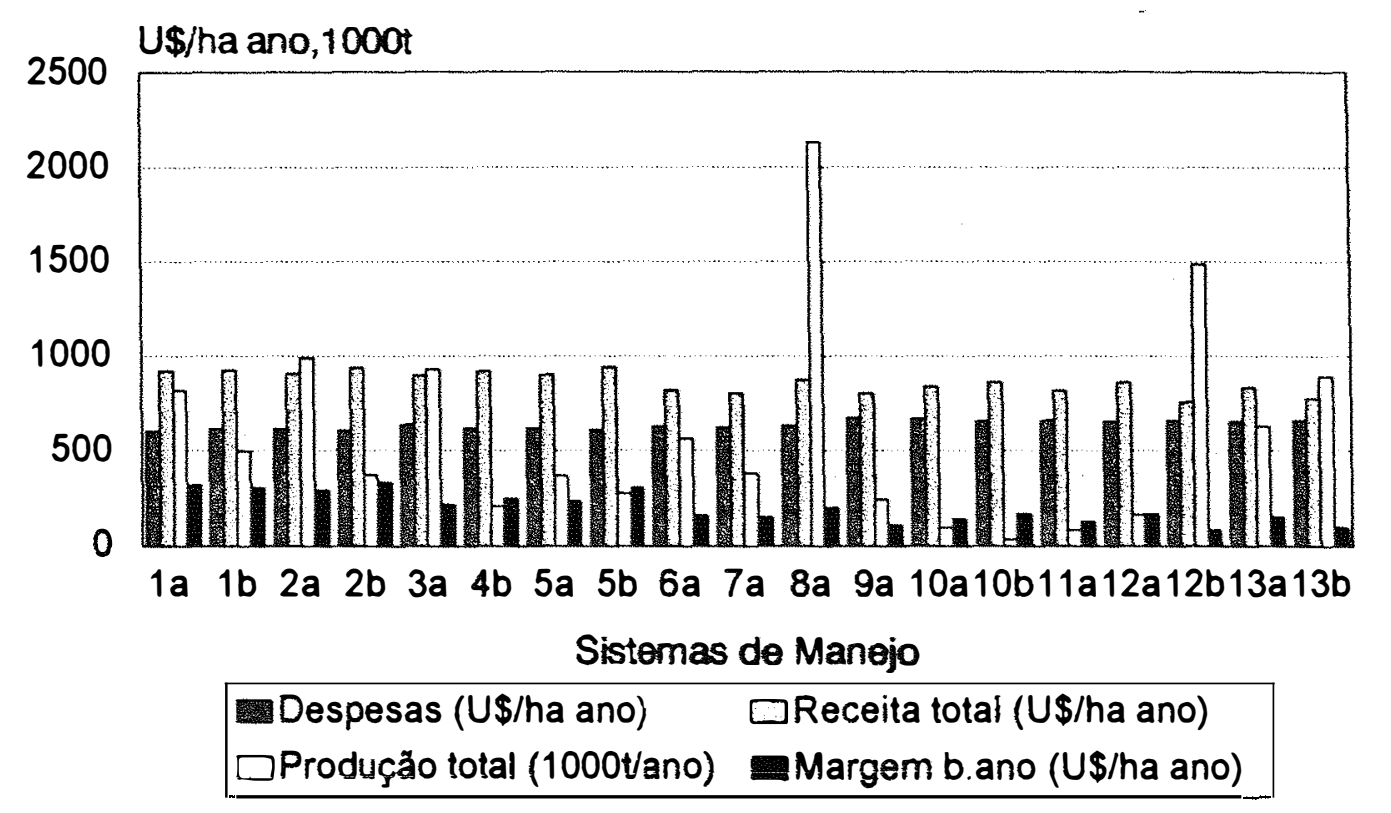

Gráfico 4: Despesa, receita, margem bruta e produção total por sistema de manejo 
Neste gráfico nota-se que a produção total varia muito entre um sistema de manejo e outro, pois as áreas dos sistemas são desiguais, existindo sistemas como o 8 a e 12 b, com área em produção bem superior aos outros sistemas.

\subsection{Cenários}

Considerando os sistemas de manejo como parte integrante de cada classes de potencial de utilização procedeu-se uma análise dos cenários de ocupação.

Para comparar a ocupação crescente do município nos cenários propostos após calculados os índices econômicos referentes a cada sistema de manejo, estes foram agrupados por cenário de modo a ser possível a avaliação e comparação do índices econômicos por cenário.

No cálculo da margem bruta média por ha total por ano para cada cenário, as margens brutas de cada sistema de manejo foram ponderadas por sua área de ocorrência, de modo a ter-se um média onde está representada a participação de cada sistema de manejo em termos de área correspondente.

\subsubsection{Comparaçåo}

A ocupação crescente das terras do município com cana-de-açúcar nos cenários propostos está representada na Figura 4, e os índices relativos aos cenários apresentados no gráfico 5 e na tabela 9 : 


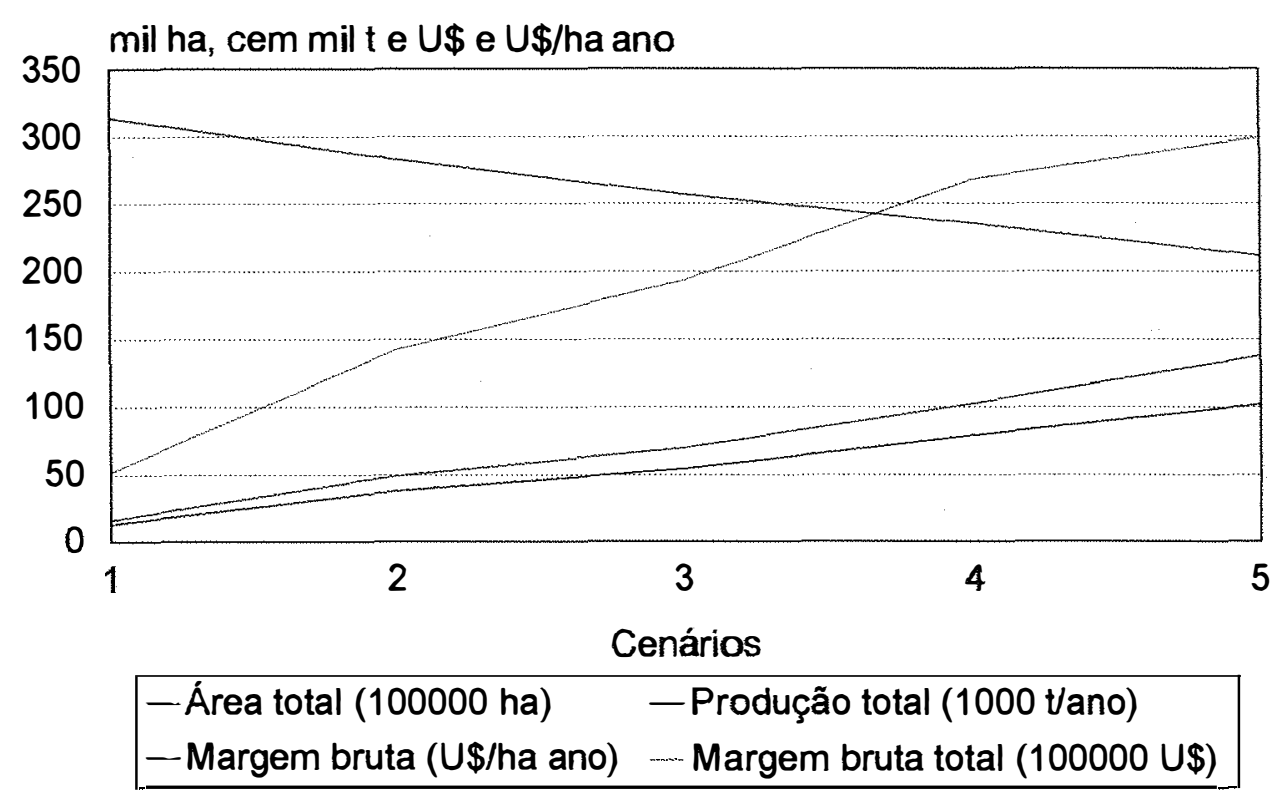

Gráfico 5: Índices relativos aos cenários

Tabela 9: Índices econômicos relativos aos cenários:

\begin{tabular}{|c|c|c|c|c|}
\hline Cenários & Area total & Produção total & Margem bruta & M bruta total \\
\hline & $10^{3} \mathrm{ha}$ & $10^{3} t$ & US/ha ano & $10^{-} \overline{\mathrm{us}}$ \\
\hline 1 & 16,38 & 13,13 & 314,52 & 51,52 \\
\hline 2 & 48 & 38,13 & 283,41 & 142,51 \\
\hline 3 & 69,28 & 54,06 & 256,96 & 192,90 \\
\hline 4 & 102,6 & 79,13 & 234,5 & 267,99 \\
\hline 5 & 137,16 & 101,87 & 211,56 & 299,22 \\
\hline
\end{tabular}

Como pode ser observado no gráfico 5 e na tabela 9 conforme estende-se a ocupação da área com cana-de-açúcar, apesar da margem bruta total acumulada em 1000U\$ ser sempre crescente, a margem bruta média dos cenários por ha total por ano (U\$/ha ano) diminue. Isto significa que a ocupação de áreas com um potencial menor, que apresentam uma menor margem bruta por sistema de manejo causa uma diminuição 
da margem bruta média total do cenário. Esta tendência deve-se ao fato de conforme estarem sendo cultivadas áreas de potencial menor, os sistemas de manejo tornam-se mais caros pela utilização de técnicas conservacionistas mais intensas.

Considerando que a produção deve ter um mínimo de margem bruta total para ser compensatória em termos de investimento e gasto de energia, alguns sistemas dentro dos cenários de ocupação aparentemente não devem ser interessantes, por apresentarem uma margem bruta muito baixa.

Considerando a moda da quantidade em tha de cana-de-açúcar paga ao arrendamento de terras para cultivo desta na região de Campinas (dados coletados de 103 municípios), publicada pelo IEA (1995), de 16,53 tha, a um custo de US 11,5 (junho de 1995) a tonelada de cana paga ao produtor, tem-se um rendimento de U\$ 190 /ha com o arrendamento. A partir deste parâmetro foram analizados os cenários.

Comparando-se o valor de margem bruta média para cada cenário com esse valor pago pelo arrendamento na região, a margem bruta aproxima-se a cada cenário deste valor, porém esta apresenta-se sempre superior. Considerando a margem bruta referente a cada sistema de manejo individualmente, a partir do sistema 6a essa apresenta-se inferior a esse valor pago pelo arrendamento, conforme observado no gráfico 2. Nestas áreas onde a margem bruta é baixa, tem-se um indício que a atividade agrícola praticada pode não ser a mais adequada, podendo haver outras atividades que por estarem melhor adaptadas ao meio físico, proporcionariam maiores rendimentos.

Comparando essse quadro com a atual ocupação das terras pode-se concluir que provavelmente em muitos casos onde está ocorrendo o cultivo da cana-de-açúcar em áreas com potencial baixo ou muito baixo esta margem bruta baixa está sendo compensada pela não utilização das devidas práticas conservacionistas, barateando assim o sistema e tornando-o viável economicamente. 
Esta situação porém, que a curto prazo gera maiores recursos, estará causando provavelmente ao longo das safras um declínio ou esgotamento do potencial produtivo das terras. Isso sem considerar os prejuízos que não são só para as terras em questão, a longo prazo, mas também para o ambiente pois os sedimentos arrastados contribuem para o assoreamento de rios e reservatórios, diminuindo a quantidade de água e piorando a qualidade desta para o consumo aumentando os gastos com tratamento desta.

Estes gastos atualmente não são considerados no processo produtivo, porém são de fundamental importância quando considerara-se a agricultura como parte de um ecossistema total e principalmente quando objetiva-se a manutenção da produtividade das culturas ao longo do tempo e a preservação dos recursos naturais.

\subsubsection{Produção atual}

Comparando a estimativa de produção para a atual (1995/96) safra do município de Piracicaba, elaborada pela Casa da Agricultura em fevereiro de 1995, na qual tem-se uma área estimada de 46.000 ha de cana em produção a uma produtividade de 74 tha (média do município), têm-se uma produção total estimada de $3.404 .000 \mathrm{t}$. Somando-se a este valor a produção relativa às áreas de cana planta $(13.000 \mathrm{ha})$, tem-se um total previsto a ser colhido nesta safra de 4.366 .000 toneladas de cana-de-açúcar.

Comparando esta produção à produção total prevista nos sistemas de manejo propostos, conclue-se que com a utilização apenas das classes de portencial Muito alto e Alto, e mais os sistemas de manejo $5 a$ e $5 b$, poderia estar sendo atingida essa produção com alguma margem de sobra (4.460.000 t previstas).

Nesta ocupação hipotética, para alcançar os níveis de produtividade propostos, subentende-se que estarão sendo seguidas as práticas de manejo referidas nos respectivos sistemas. 


\subsubsection{Cenário hipotético e quadro atual}

A comparação entre este cenário hipotético de ocupação onde estaria sendo atingida a atual produção total do município e as áreas de ocupação real (uso em 1991), podem ser observadas na Figura 5 e na Tabela 10.

\section{Comparação entre as atuais áreas de produção de} cana-de-açúcar e o cenário hipotético

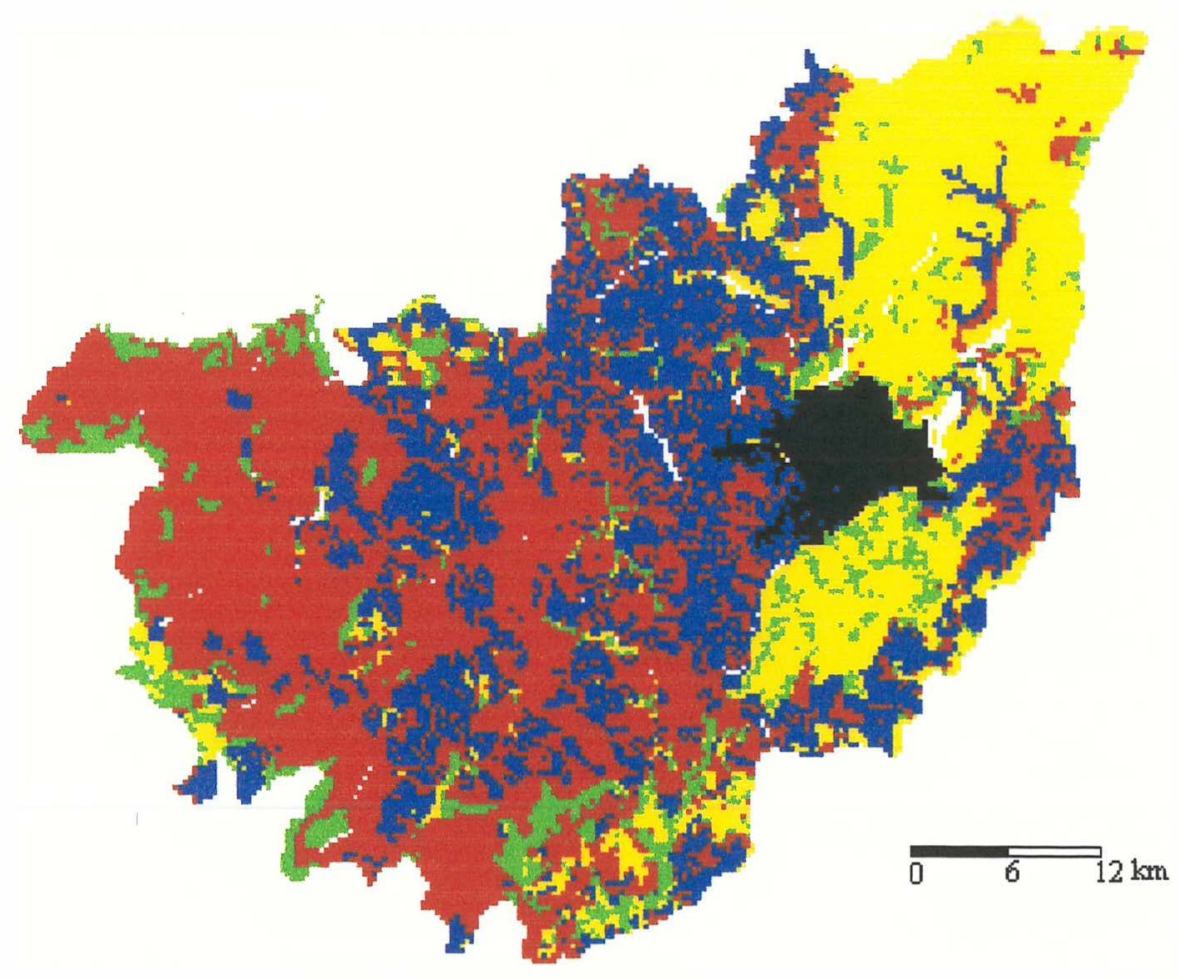

pot.adeq c/ cana pot.adeq sicana pot.inadeq s/cana pot.inadeq c/cana

Figura 5: Comparação entre as áreas de produção de cana-de-açúcar em 1991 e o cenário hipotético. 
Tabela 10: Comparação entre as áreas de produção de cana-de-açúcar em 1991 e o cenário hipotético

\begin{tabular}{lc}
\hline \multicolumn{1}{c}{ Situaģão } & Área correspondente \\
\hline $\begin{array}{l}\text { Cultura da cana-de-açúcar em áreas com potencial } \\
\text { elevado (Ma, A, 5a, 5b) }\end{array}$ & $40.818,75(23,2 \%)$ \\
$\begin{array}{l}\text { Cultura da cana-de-açúcar em áreas com potencial } \\
\text { baixo (M, B, Mb) }\end{array}$ & $45.668,75$ ha $(25,9 \%)$ \\
Áreas com potencial baixo sem cana-de-açúcar & $74.125,00$ ha $(42,15 \%)$ \\
Áreas com potencial elevado para cana-de-açúcar & $15.525,00$ ha $(8,8 \%)$ \\
\hline
\end{tabular}

Pela tabela 10 , observa-se que apenas $23,2 \%$ da cultura da cana-de-açucar está realmente em áreas com potencial elevado para esta utilização e praticamente $26 \%$ das áreas que estão plantadas com cana-de-açúcar tem baixo potencial para tal uso.

Este quadro indica que existe praticamente $26 \%$ da área com alta chance de estar em intenso processo de degradação pois são áreas ocupadas com cana-de-açúcar e possuem potencial baixo para o cultivo desta, com maiores riscos de erosão. Provavelmente nessa áreas o manejo está sendo feito de forma à garantir a máxima produção dentro de um custo o mais reduzido possível, não levando em consideração as limitações naturais da referida área. Mesmo nas áreas com potencial Alto ou Muito alto pode estar ocorrendo uma não utilização das técnicas conservacionistas adequadas, porém por apresentarem condições adáficas mais favoráveis para o cultivo da cana-deaçúcar este manejo inadequado não deve estar causando tão sérios prejuízos ambientais.

Ao mesmo tempo existe quase $9 \%$ da área que poderia estar sendo utilizada com cana-de-açúcar e não está. 


\subsection{Quadro ideal}

Considerando uma utilização hipotética apenas das áreas suficientes para representar a produção atual de cana-de-açúcar do município, sobrariam áreas que poderiam estar destinadas a outros usos. Estes usos poderiam trazer rendimentos até superiores à cana-de-açúcar pois estariam melhor adaptados às condições não tão favoráveis a cana-de-açúcar.

Dentro deste contexto, uma opção viável é o plantio de florestas comerciais. Segundo CASTANHO FILHO (1994) o setor florestal como fornecedor de matéria prima gera inúmeros empregos e funções. Por ter ciclos longos de produção gera postos de trabalho permanente, contribuindo para minimizar a crise estrutural de emprego, que se agravou nestes anos 90 , ao fixar contingente populacional no meio rural. Ao mesmo tempo é uma opção econômica para pequenos, médios e grandes empresários rurais que podem ser envolvidos diretamente no processo agroflorestal.

A floresta comercial, especificamente para essse caso o Eucalipto é uma alternativa interessante, pois o mercado fornece indicações de que existe demanda potencial para uma maior produção de madeira para papel e celulose (VEIGA FILHO \& RODRIGUES VEIGA, 1993) na região.

O município de Piracicaba encontra-se perto de grandes fábricas de papel e celulose, tendo teoricamente potencial para o desenvolvimento da atividade florestal.

Nesse contexto, fazendo-se uma estimativa aproximada do que poderia representar o plantio de florestas, especificamente o Eucalipto, em termos de margem bruta por ha/ano, tem-se o seguinte quadro: Com base em uma estimativa de custo de um sistema de produção da Cia. Suzano de Papel e Celulose, detalhado no anexo 8, no qual tem-se um custo final de 1,97 U\$ por estereo (st), considerando um sistema para utilização da madeira para celulose com um ciclo total da cultura de 14 anos, 
possibilitando dois cortes, tem-se uma produção total está em torno de 630 st/ha no total, representando 45 st ha/ano.

Sendo comercializado a 5,05 U\$ o estereo (FLORESTAR ESTATÍSTICO, 1994/5) em pé, poderia gerar uma receita de 227,25 U\$/ano. A despesa correspondente estaria em torno de 88,65 U\$/ano, o que representaria uma margem bruta de 138,65 U\$/ano.

Pode-se assim ter uma idéia de que para algumas áreas onde a margem bruta por ha/ano para a cana-de-açúcar apresenta-se inferior ao valor desta para o Eucalipto, talvez este fosse uma opção de atividade mais vantajosa econômicamente.

Outra atividade que pode estar sendo estimulada é a pecuária de corte. Atualmente as pastagens ocupam praticamente $26 \%$ do municipio, sendo em sua maioria praticada a pecuária extensiva. As pastagens podem estar sendo melhor manejadas de modo a ter-se mesmo no sistema de pastejo extensivo, bons índices de produtividade.

Estimando-se a receita que poderia proporcionar a pecuária de corte, com base em um sistema de produção de pastejo contínuo comumente adotada na região detalhado no anexo 8, tem-se a seguinte espectativa: Considerando um boi gordo com 15 arrobas sendo vendido a 20 U\$ a arroba (Informativo Rural, julho de1995), esse boi estaria rendendo U\$ 300. Considerando uma lotação de $1 \mathrm{cab} / \mathrm{ha}$ tem-se uma receita de U $\$ 300$ por ha. Em um sistema de produção extensivo, com baixo nível da manejo, cuja depesa total por hectare para engorda é de U\$ 225,00 (periodo de 2,5 anos incluindo o preço do boi magro), tem-se uma margem bruta por ciclo de engorda de U\$ 75,00. Deste modo a margem bruta por ha ano é da ordem de U $\$ 30,00$ por ha.

Porém esse sistema por apresentar baixíssimo nivel de investimento e manejo promove uma margem bruta por ha muito baixa. A fim de se ter maiores rendimentos 
com a atividade pecuária a ponto desta ser competitiva em termos econômicos com a cana-de-açúcar, deveriam ser incentivados nas áreas com pouca aptidão para esta cultura, sistemas de produção com um nível tecnológico mais elevado, com maiores retornos econômicos.

Porém para se tomar a decisão sobre o melhor uso a que se destinarão as terras é necessário levar em consideração primeiramente os aspectos relacionados ao meio fisico, pois estes interferem diretamente na estimativa de rendimento que a cultura pode oferecer.

Em um segundo momento é necessário se fazer um estudo aprofundado da conjuntura econômica a que determinada cultura está inserida e desta maneira avaliar-se o seu potencial econômico para a tomada de decisão sobre o que seria o melhor investimento.

\subsection{Consideraçōes finais}

Este estudo baseou-se no potencial das terras de Piracicaba para o cultivo da cana-de-açúcar pela sua abrangência em área cultivada e pela importância econômica no município de Piracicaba. Porém, sugere-se para estudos posteriores, a avaliação do potencial das terras para outras culturas, por exemplo culturas anuais como milho, feijão, soja e arroz.

Os sistemas propostos para a cana-de-açúcar não são os únicos possíveis, havendo outras combinações de operações que poderiam estar chegando à resultados semelhantes sob o aspecto conservacionista. Entende-se que os sistemas adotados no presente estudo são algumas opções de manejo adequados às situaçð̃es específicas destas áreas. 
Dentro do sistema de produção de cana-de-açúcar pode-se, para um estudo futuro considerar também a rotação com culturas como soja ou amendoim, prática comum em outras regiões mas não tradicionais na região de Piracicaba. A rotação com essas culturas tráz inúmeras vantagens, não só pelos benefícios referentes à incorporação do nitrogênio ao solo, como também a possibilidade de custear a implantação da cultura da cana-de-açúcar instalada a seguir pela comercialização da colheita anterior.

A prática de plantio direto também não foi considerada no presente estudo, embora admite-se ser uma prática gradativamente difundida em outras regiões com resultados positivos, e com potencial para o estabelecimeto nessa região.

$\mathrm{O}$ potencial para o cultivo de pastagem e eucalipto bem como o rendimento destas culturas foi apenas indicado. Sugere-se para um estudo futuro o aprofundamento nestas culturas, avaliando-se mais detalhadamente o potencial destas culturas.

Por fim sugere-se que estudos desse tipo sejam feitos em maior número, e que as idéias e as questões levantadas e indicadas nestes sejam levadas em consideração pelos órgãos planejadores para tomada de decisões, principalmente e em áreas que estejam em processo de ocupação ou alterações no uso das terras 


\section{CONCLUSÕES}

\subsection{Conclusões gerais}

*Em trabalho anterior (SPAROVEK \& LEPSCH, 1994) observou-se que a expansão da lavoura canavieira de 1962 a 1991 havia se dado principalmente nas áreas anteriormente ocupadas com pastagens. Estas áreas, em sua maioria, foram classificadas no presente estudo como tendo um potencial para a cana-de-açúcar de médio a muito baixo. Conforme o indicado neste estudo, estas áreas apresentam um risco de degradação alto, proporcionando, se adotadas as medidas conservacionistas adequadas, uma margem bruta baixa ao sistema de produção. Porém, de maneira geral, esta margem bruta baixa é superior àquela proporcionada pela pecuária extensiva, com o baixo nível de manejo normalmente praticado nestas áreas, o que pode explicar a ocupação dessas com a cana-de-açúcar.

No contexto da necessidade de produção para suprir a demanda por parte das usinas, considerando que atualmente esta esteja sendo satisfeita, seria possível estar a produção de cana-de-açúcar concentrada apenas nas áreas com potencial elevado para esta cultura e o total de produção atual estaria sendo atingido. Nestas áreas com potencial mais elevado, a margem bruta é maior e o risco de degradação é menor.

Para as áreas onde o potencial para a cana-de-açúcar é baixo, poderiam estar sendo cultivadas florestas comerciais como Eucalipto, por exemplo, proporcionando em 
parte destas áreas rendimentos mais altos que a cana-de-açúcar, nos sistemas propostos. Já a pecuária extensiva, para ser competitiva com a cana-de-açúcar em termos econômicos seria necessário um nível de manejo mais elevado para proporcionar uma maior margem bruta.

Existem outras culturas que poderiam proporcionar rendimentos ainda maiores, porém seriam necessários estudos mais aprofundados para a definição de opções de culturas viáveis técnica e econômicamente.

Talvez para reverter o processo de degradação a que muitas áreas estão sujeitas, fosse mais eficiente investir em estudos e esforços para aumentar os níveis de produtividade das áreas com cana-de-açúcar que tem elevado potencial. Nas áreas onde o potencial é baixo seria desejável estimular outras atividades agrícolas que pudessem proporcionar iguais ou maiores rendimentos que a cana-de-açúcar e que seriam mais adequados sob o aspecto conservacionista.

\subsection{Conclusōes específicas}

A metodologia proposta para avaliação do potencial das terras de Piracicaba para o cultivo da cana-de-açúcar apresentou rapidez e eficiência na obtenção dos resultados.

* O crescente uso das terras do município de Piracicaba com a cana-de-açúcar, nos sistemas propostos, conforme estende-se a áreas com potenciais de utilização decrescentes traz considerável diminuição na margem bruta por ha total por ano, tanto na média geral dos cenários de ocupação como nos sistemas de manejo.

Considerando as práticas conservacionistas necessárias para controlar os processos erosivos e manter os níveis de produtividade ao longo do tempo, a utilização 
de terras com potencial baixo a muito baixo, implicaria em rendimentos econômicos muito baixos. :

Provavelmente nas áreas com potencial para o cultivo da cana-de-açúcar de médio a baixo, onde aumentam-se os custos de implantação diminuindo a margem bruta, técnicas conservacionistas são utilizadas em menor intensidade para diminuir a despesa total, devendo este fato estar contribuindo para a degradação das terras à longo prazo.

* A utilização das terras dentro de seu potencial traz maior retorno econômico ao sistema produtivo, conforme foi indicado neste estudo. $\downarrow$

* Utilizando apenas as áreas com potencial para a produção de cana-de-açúcar muito alto, alto e parte do médio, seria possível chegar a produção total esperada para a safra 1995/6 no municipio de Piracicaba. Desta maneira a cultura estaria estabelecida em áreas de menor risco de degradação possibilitando a diminuição nos custos de implantação e mantendo uma margem bruta média alta. Ao mesmo tempo, as áreas de potencial baixo e muito baixo que atualmente são utilizadas para o cultivo da cana-deaçúcar, poderiam estar sendo utilizadas com outras culturas, possibilitando rendimentos maiores e diminuição no risco de degradação das terras bem como outros prejuizos ambientais dificeis de serem quantificados monetariamente. 


\section{REFERÊNCIAS BIBLIOGRÁFICAS}

ANGULO, R.J. Relacões entre a erodibilidade e algumas propriedades de solos brasileiros. Curitiba, 1983. 129 p. (Mestrado - Universidade Federal do Paraná).

ARAÚJO, P.C.I. Estrutura agrária dos municípios de Pinheiro, São Bento e Palmerândia, na baixada ocidental maranhense (diagnóstico preliminar). São Luis, EMAPA, 1988.

ASSAD, E.D. \& SANO, E.E. Sistema de Informação Geográficas; aplicações na agricultura. Planaltina, EMBRAPA/ CPAC, 1993. 247p.

BARBIERI, V. Condicionamento climático da produtividade de caca-de-açúcar (Saccarum spp.): Um modelo matemático fisiológoco de estimativa. Piracicaba, 1993, 142 p. (Doutorado - Escola Superior de Agricultura "Luiz de Queiroz"/ USP).

BAVEL, C.H.M. Men weight diameter of soil aggregates as a statistical index of agregation. Soil Science of Society of America Procedings, Madison, 14: 20-3, 1949.

BEAUCLAIR, E. G. F. Produtividade da cana-de-açúcar em função de alguns macronutrientes presentes no caldo e no solo. Piracicaba, 1994. 97p. (Doutorado - Escola Superior de Agricultura "Luiz de Queiroz"/USP).

BENNETT, H. H. Soil conservation. New York, Mac Graw-Hill, 1939. 993p. 
BERTONI, J.\& LOMBARDI NETO, F. Conservação do solo. São Paulo, Icone, 1990. 335p.

BITTENCOURT, V.C.; CARMELLO, Q.A. de C.; BEAUCLAIR, E.G.F.; JOÃO,J.; CLEMENTE, J.L. Produtividade da cana-de-açúcar e suas relaçðes com fertilidade dos solos e manejo da cultura. STAB. açúcar Alcool e Subprodutos, Piracicaba, 8 (5/6): 10-4, maio/agos. 1990.

BITTENCOURT, V.C.; ClARET, A.C.; CARMELlO, Q. A. de C.; CARVALHO, A. J. L. Produtividade da cana-de-aúcar e fertilidade do solo. STAB. Acúcar Alcool e Subprodutos, Piracicaba, 8 (20): 41-5. nov/dez 1989.

BRAGA Jr., R.L.C. Interação genótipo ambiente em novos clones de cana-de-açúcar. In: Seminário Copersucar de Tecnologia Agronômica, 6. Piracicaba, 1994. Anais. Copersucar. p. 119-29.

BRANDT, S. A. \& OLIVEIRA, I. G. O planejamento da nova empresa rural brasileira. Rio de Janeiro, APEC, 1973. 260p.

CARVALHO, M.P.; LOMBARDI NETO, F.; VASQUES FILHO, J.; CATANEO, A. Índices de erosividade da chuva correlacionados com as perdas de um Podzlólico Vermelho Amarelo eutrófico, textura argilosa/muito argilosa de Mococa (SP): primeira aproximação do fator erodibilidade do solo. Revista Brasileira de Ciência do Solo, Campinas, 13: 237-42, 1989.

CASTANHO FILHO, E.P. Florestas, novas opçðes de investimento. In Florestar Estatístico, São Paulo, 2 (5): 1994.

COLleTI, J.T. Técnica cultural de plantio. In: Paranhos S. B., coord. Cana de açucar; cultivo e utilização. Campinas, Fundação Cargill, 1987. p.284-328. 
CONDE, A.J.; DONZELLI, J.L.; PIVETTA,A.R.; LOPES, C.R. Conservação de solos em um Podzólico Vernnelho Amarelo. In: Seminário Copersucar de tecnologia agronômica, 6,. Piracicaba, 1994. Anais, São Paulo, Copersucar abril/maio de.1994. 22-7.

COPERSUCAR. Resultados obtidos pelo "Controle Técnico Agronômico"na safra 80/81. In Seminário de Tecnologia Agronômica, 1, Anais. Piracicaba, Copersucar, 1982. 241-52.

CORTINA, N. Planejamento de empresas rurais em Santa Catarina. Piracicaba, 1992. 112 p. (Mestrado - Escola Superior de Agricultura "Luiz de Queiroz"/ USP).

COTTAS, L.R. Estudos geológicos-geotécnicos aplicados, ao planejamento urbano de Rio Claro. 1983. sn. (Doutorado - Instituto de Geociências/ USP).

DAVIDSON, D.A. Application of Geographical Information Systems to land evaluation. Course on land evaluation, held at UIMP, Valencia, Palau de Pineda, 1992. $29 \mathrm{p}$.

DENARDIN, J.E. Erodibilidade do solo estimada por meio de parâmetros físicos e químicos. Piracicaba, 1990. 114 p. (Doutorado - Escola Superior de Agricultura "Luiz de Queiroz"/ USP).

DIEGUES, A.C. Desenvolvimento sustentado, gerenciamento geoambiental e o de recursos naturais. Cadernos FUNDAP, São Paulo, 9 (16) : 33-45, jun. 1989.

DIEPEN, C. A.; KEULEN, H.; WOLF, J.; BERKHOUT, A. A. Land Evaluation: from intuition to quantification. Advances in Soil Science, New York, 15: 140-204, 1991. 
FAETH, P. Evaluating agricultural policy and the sustainability of production systems:An economic framework. Journal of Soil and Water Conservation, Ankeny, 48 (2): 94-9,1993.

FAO. Water and sustainable development. Rome, 1990. 48p.

FERNANDEZ,R.N.; RUSINKIEWICZ,M.; SILVA,L.M.; JOAHANNSEN,C. Design and implementation of soil geografhic database for rural planning and management. Journal of Soil and Water Conservation, Ankeny, 48 (2):140-5, 1993.

FLORESTAR ESTATÍSTICO, SÃO PAULO, (2), 6- 1994/5. p.51.

FORMAGGIO, A.R.; ALVES,D.S.; EPIPHANIO J.C.N .Sistemas de Informaç̃es geográficas na obtenção de mapas de aptidão agrícola e de taxa de adequação de uso das terras. Revista Brasileira de Ciência do Solo, Campinas, 16: 249-56, 1992.

FOSTER, G. R.; McCOOL D.K.; RENARD K.G.; MOLDENHAUER W.C.; Conversion of the universal soil loss equation to SI metric units. Journal of Soil and Water Conservation, Ankeny, nov-dez : 355-59,1981.

FRANÇA, G.V. Interpretação de levantamento de solos para fins conservacionistas. Piracicaba, ESALQ 1980.

FREITAS, G. R. Preparo do solo. In: PARANHOS S. B., coord. Cana-de-açucar; cultivo e utilização. Campinas, Fundação Cargill; 1987. p. 271-83.

GOLLEY, F; BAUDRY, J.; BERRY, R.J.; BORNKAMM, R.; DAHLBERG, K.; JANSSON, A.M.; KING, J.; LEE; J.; LENZ, R.; SHARITZ, R.; SVEDIN, V.; Bulletin of International Society of Soil Science, Vienna, (84) :17-21 1993/2. 
HENKLAN, J.C. Erodibilidade de latossolos do Estado do Paraná. Aplicabilidade do método nomográfico. Piracicaba, 1980. 75 p. (Mestrado-Escola Superior de Agricultura "Luiz de Queiroz"/ USP).

HOLÝ, M. Erosion and environment. Oxford, Pergamon Press, 1984. 225p. (Environmental Science and Aplication, 9).

INSTITUTO DE ECONOMIA AGRÍCOLA. Informaçōes econômicas, 25, (2): 110, 130-3. 1995.

INFORMATIVO RURAL . Publicação semanal da Sociedade Rural Brasileira. São Paulo, ano $1 \mathrm{n}, 28.1995$.

JACOBS, G.; ROLOFF, G.; BISCAIA, R.M.;MERTEN, G. Variaçōes sazonais da erodibilidade do solo sob condiçōes de chuva natural. In: Congresso Brasileiro de Ciência do Solo. Viçosa, 1995. (VI), p. 1994-5.

JOAQUIM, A.C.; BELINASO, I.F.; DONZELLI, J.L.;QUADROS, A.C.; BARATA, M.Q. Potencial e manejo de solos cultivados com cana-de-açúcar. In: Seminário de Tecnologia Agronômica, 6. Piracicaba, 1994. Anais. São Paulo, Copersucar, 1994, a. p. 1-9.

JOAQUIM, A.C.; KÖLLER, H.W.; HIRAI, J.M. JUNIOR, C.D.; PAES, L.A.D.; SANTARELlA, M.; JUNIOR, A. R.; PENATTI, C. P. Controle mútuo agrícola. In: Seminário de Tecnologia Agronômica, 6. Piracicaba, 1994. Anais. São Paulo, Copersucar, 1994 b. p. 19-30.

KOFFLER, N.F. \& DONZELLI, P.L. Avaliação dos solos brasileiros para a cultura da cana-de-açúcar. In: PARANHOS S. B., coord. Cana de açucar: cultivo e utilização, Campinas, Fundação Cargill, 1987. p.19-39. 
KOFFLER, N.P.\& MORETTI, E. Diagnostico do uso agrícola das terras do município de Rio Claro. Geografia, Rio Claro. 16 (2): 1-76, 1991.

KRUMBEIN, W.C. Size frequency distribuition of sediments. Journal Sed. Petrol.,4: 65-77, 1934.

LOPES ASSAD, M.L. Uso de um sistema de informações geográficas na determinação da aptidão agrícola das terras. Revista Brasileira de Ciência do Solo, Campinas, 19:133-9, 1995 .

LEPSCH, I.F.; BELINAZZI Jr; R.; BERTOLINI, D.; ESPÍNDOLA, C.R. Manual para levantamento utilitário do meio físico e classificação de terras no sistema de capacidade de uso; $4^{\mathrm{a}}$-aproximação. Campinas, Sociedade Brasileira de Ciência do Solo, 1991. $175 \mathrm{p}$.

XLORANDI, R. Caracterização dos solos das áreas urbana e suburbana de São Carlos(SP) e suas aplicações. Piracicaba, 1985. 181 p. (Doutorado - Escola Superior de Agricultura "Luiz de Queiroz"/USP).

MARGARIDO, L.A.C.; BORSARI FILHO, S.; GEMENTE, A.C. Avaliação técnica e econômica de sistemas de produção de cana de açúcar para agricultores da região de Guariba-SP: um teste comparativo para alguns casos. Brasil Açucareiro, Rio de Janeiro, 106 (3): 42-7, 1988.

MATIOLI, C.S. \& BARCELOS, J. Irrigação suplementar de cana de açúcar. Estudo comparativo: Pivo central $x$ auto propelido. Alcool \& Açúcar, São Paulo, 73: 22-7, abril maio 1994.

NUNES, N.D. Variedades de cana-de-açúcar: Perspectivas de substituição e expectativas de ganho e produtividade. STAB, Açúcar, Alcool e Subprodutos, Piracicaba, 10 (3): 9-13, 1992. 
OLIVEIRA, J.B., \& PRADO, H. Carta pedológica semi-detalhada do Estado de São Paulo; folha de Piracicaba. Campinas, Instituto Agronômico; Instituto Geográfico e Cartográfico. 1989. (Escala 1:100.000).

OLIVEIRA, M. Os solos e o ambiente agrícola no sistema Piranhas Açu, R.N. Viçosa, 1988. p.312. (Doutorado - Universidade Federal de Viçosa)

OMETO, J. C. Bioclimatologia vegetal, São Paulo, Ceres, 1981. 440 p.

PARANÁ (Estado). Programa de manejo integrado dos solos e da água em microbacias. Curitiba, 1987. $34 \mathrm{p}$.

PENNATI, C. P.; ZOTARELli, E.M.M.; BENEDITINI, M.S.; ChALITA, R.; FERREIRA, E.S.; KORNDONFER, G.H. CACERES, N.T.; CAMBRIA, S. Recomendação de adubação para a cultura da cana-de-açúcar. In: Seminário de Tecnologia agronômica, 4. Piracicaba, 1988. Anais. São Paulo, Copersucar 1988. p 103-13.

PERTICARRIARI, J.G. \& IDE, B.Y. Cultivo mínimo. In: Seminário de tecnologia Agonômica , 4. Piracicaba, 1988. Anais. São Paulo, Copersucar 1988. p. 241-52.

PIRACICABA Prefeitura municipal. Plano Diretor de desenvolvimento de Piracicaba. Piracicaba, 1992. $214 \mathrm{p}$.

RANZANI, G. Solos para agricultura. In: INSTITUTO BRASILEIRO DE POTASSA. Cultura e adubação da cana de açúcar. São Paulo, 1964. cap 4, p 99-111.

RESCK D.V.S. Manejo e conservação do solo em microbacias hidrográficas na regiåo dos cerrados. Planaltina, EMBRAPACPAC, 1992. 
RESENDE, M; CURI, N; SANTANA, D.P. Pedologia e fertilidade do solo: interaç̃os e aplicações. Brasilia, Ministério da Educação, Lavras ESAL, Piracicaba: POTAFÓS, 1988. $81 \mathrm{p}$.

RUBIO,J.L.; MOLINA, M.J.; SANCHEZ, J. Land use recomendations for soil conservation planning in mediterranean environments. In: SCHWERTMANN, V., RICKSON, R.j., AUERSWALD, K., ed. Soil erosion protection measures in Europe. Cremlinger, CATENA, 1989: 207-16. (Soil Technology series 1)

RYFF, T.B.B. Agricultura e meio ambiente: uma abordagem econômica. Agroanalysis, Rio de Janeiro, 15 (4) : 7-13, 1995.

SÃo PAULO (Estado)- Secretaria do Meio Ambiente. Estabelecimento de metas e reenquadramento dos corpos d'água; Bacia do Rio Piracicaba. São Paulo, 1994. $81 \mathrm{p}$.

SILVA, I. F.; ANDRADE A.P. ; CAMPOS FILHO, O.R. Erodibilidade de seis solos do semi árido paraibano obtido com chuva simulada e método nomográfico. Revista Brasileira de Ciência doSolo, Campinas, 10: 283-7, 1985.

SILVA. J.R.C.; DEGLORIA, S.D. PHILIPSON, W.R. Mc NEIL, R.J. Estudo da mudança de uso da terra através de um sistema de análise georreferenciada. Revista Brasileira de Ciência do Solo, Campinas, 17: 451-7, 1993.

SMITH,D.D. \& WISCHMEIER, W. H. Rainfall erosion. Advance Agronomy, 14: 109-45. 1962.

SPAROVEK, G; JONG VAN LIER, Q; LEPSCH, I.F. GMAP: Um programa de manipulação de mapas temáticos adaptado a computadores de pequeno porte. $\mathbf{O}$ exemplo do município de Piracicaba. Boletim Informativo da Sociedade Brasileira de Ciência do Solo, Campinas, 18 (1):15-9, 1993. 
SPAROVEK, G. \& LEPSCH, I.F. Diagnóstico de uso e aptidão das terras agrícolas de Piracicaba. Piracicaba, ESALQ/ Depto de Solos, 1994.

TEIXEIRA,A.L.A. Notas sobre otimização de um SIG para microcomputadores da linha IBM-PC. Boletim de Geografía Teorética, Rio Claro, 18 (35/36): 105-10. 1989.

TEIXEIRA, A. L. A. MORETI, E., CHRISTOFOLETTI, A. Introdução aos Sistemas de Informação Geográfica. Rio Claro, 1992. 80p.

VENTURA, S.J.; CHRISMAN, N.R.; CONNORS, K.; GURDA, R.F.; MARTIN,R.W. A land information system for soil erosion control planning. Journal of Soil and Water Conservation, Ankeny, 43 (3): 230-3, 1988.

VENTURA, S.J. \& GIAMPETRONI A.D. Wisconsin conservationists respond to field office overload. Journal of Soil and W ater Conservation, Ankeny,US, 48 (2): 83-9, 1993.

VEIGA FILHO, A.A. \& RODRIGUES VEIGA, J.E.R. In: Informaçōes Econômicas, São Paulo, 23 (5): 19-24,1993.

WISCHMEIER, W.H. \& MANNERING J.V. Relation of soil properties to its erodibility. Soil Science Society of America Proceedings. Madison: 33, 1969.

WISCHEMEIER, W. H.; JOHNSON C.B. e CROSS B.V. A erodibility nomograph for farmland and construction sites. Journal of Soil and Water Conservation, Ankeny, 26 (6): 189-93, 1971.

WISCHEMEIER, W.H. \& SMITH, D.D. Predicting rainfall erosion losses - a guide conservation planning. Washington, USDA. 1978.58 p. (Agricultural Handbook, 537). 
YOUNG, R.A.; RÖMKENS, M.J.M.; Mc COOL, D.K. Temporal variations in soil erodibility. In BRYAN, R.B., ed. Soil erosion; experiments and models. Cremlinger, CATENA, 17, 41-53, 1990.

ZAMBELLO J.R.; ORLANDO FILHO, J.O; MACEDO, N. Conservação dos solos em cana-de-açúcar. Boletim técnico PLANALSUCAR, Piracicaba, 5 (2): 7-24, fev. 1983 


\section{ANEXO 1}

Dados analíticos do Levantamento Pedológico

Semi - detalhado de Piracicaba 


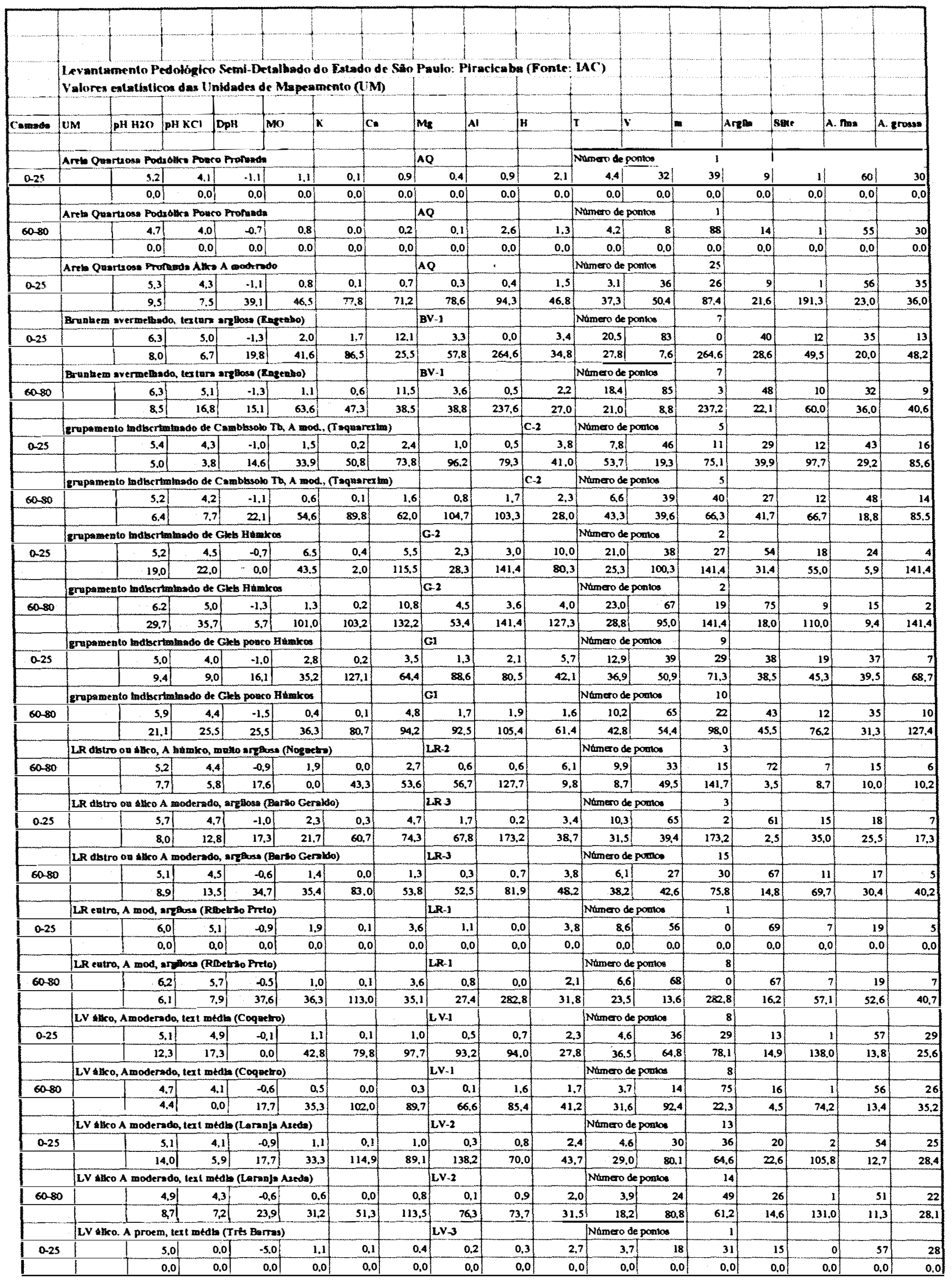


Levantamento Prdotogicu Semi-Detalhado do Fstado de Sâ Pauk: Piracicaba (Fonte: IAC)

Valores extatisticas das Inidades de Mapeamento ( $M)$

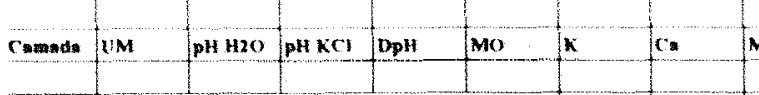

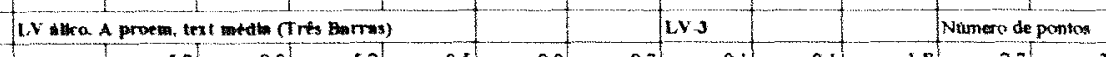

\begin{tabular}{r|r|r|r|r|r|r|r|r|r|r|}
\hline $60-80$ & 5.2 & 0.0 & -5.2 & 0.5 & 0.0 & 0.7 & 0.1 & 0.4 & 1.8 & 2.7
\end{tabular}

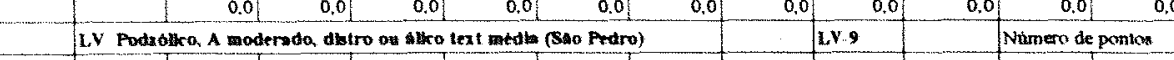

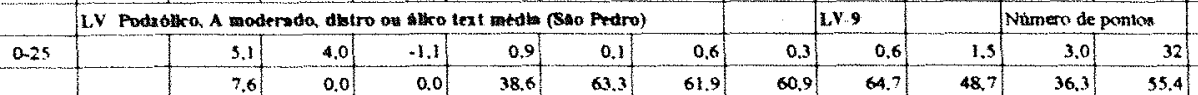

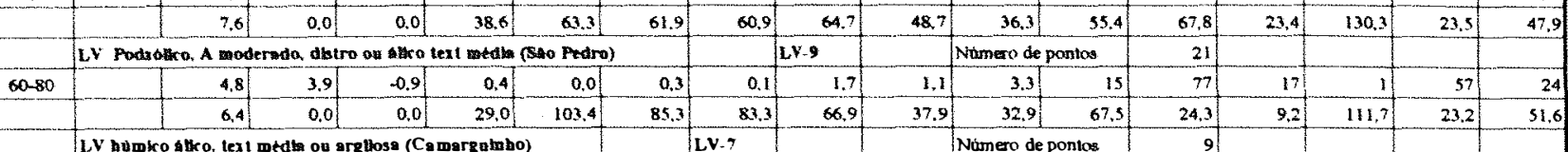

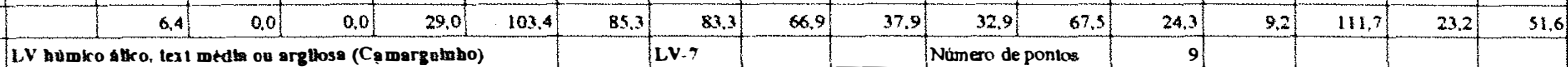

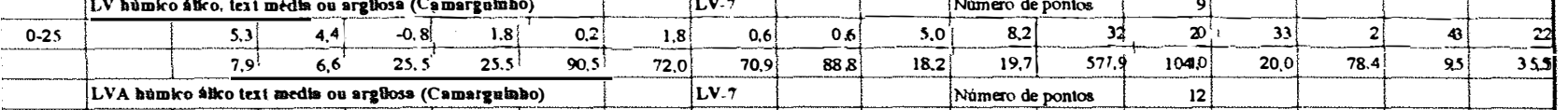

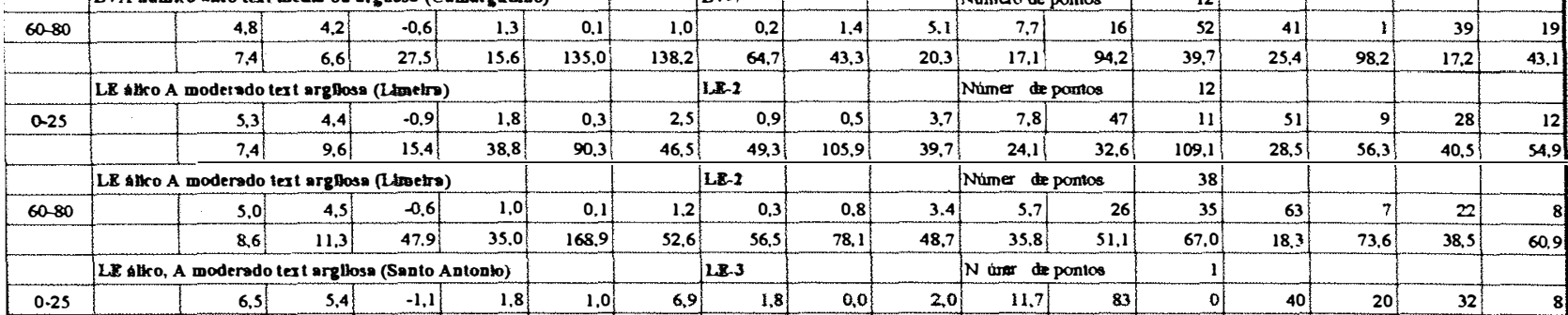

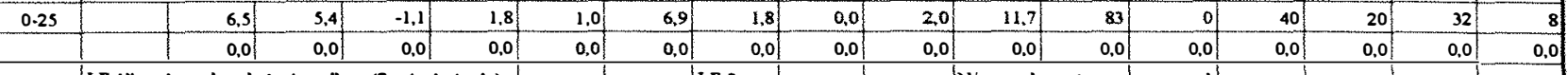

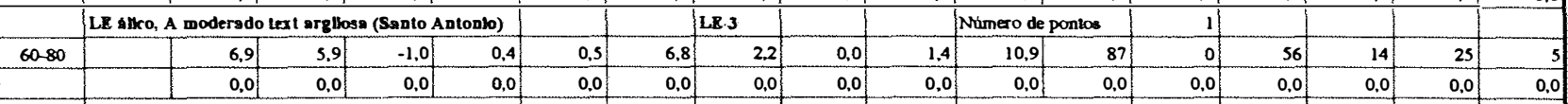

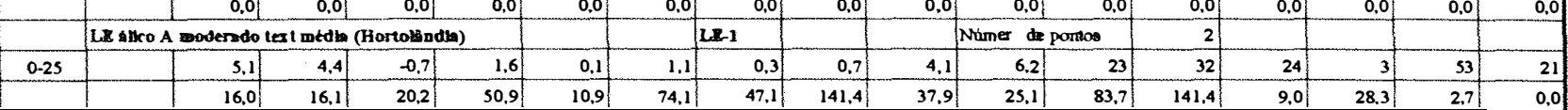

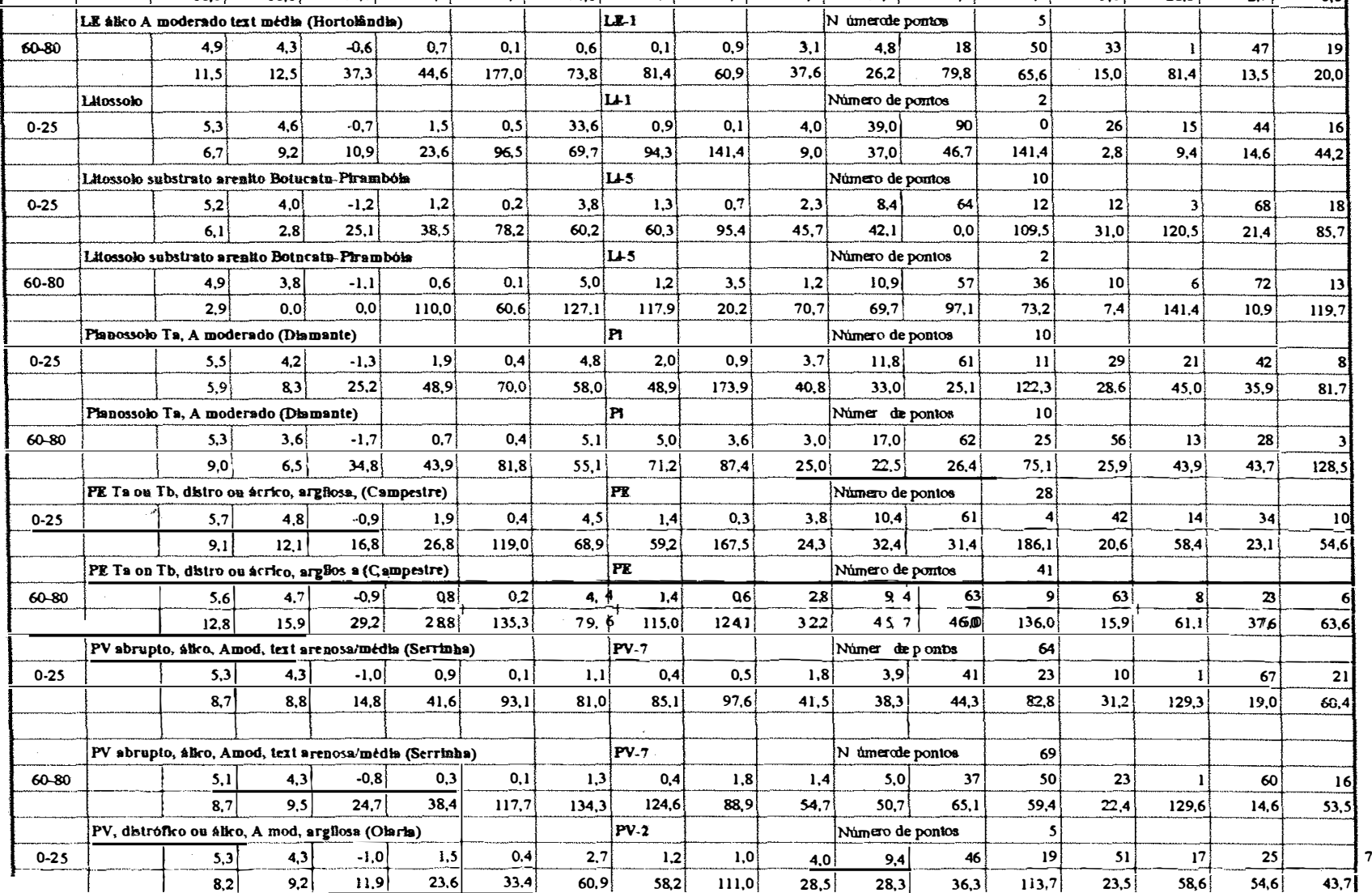




\begin{tabular}{|c|c|c|c|c|c|c|c|c|c|c|c|c|c|c|c|c|c|}
\hline & & & & & & & & & & & & & & & & & \\
\hline & & & & & & & & & & & & & & & & & \\
\hline & & & & & & & & & & & & & & & & & \\
\hline & & \multicolumn{4}{|c|}{ PV, dutrofico os Alka, A mod, argllose (Olarta) } & & & & & & \multicolumn{2}{|c|}{ Numero de pontoa } & 6. & & & & \\
\hline $60-80$ & & & & & & & & & & 3.3 & 7.5 & 22 & $\infty$ & 67 & 16 & 15 & 3 \\
\hline \multirow{4}{*}{$0-25$} & \multicolumn{6}{|c|}{ PV Ta, cutro A wod, motdha/mutho arghose pP (Mandwca) } & & PV-10 & & & \multicolumn{2}{|c|}{ Nümero de ponkos } & 17. & & & & \\
\hline & & 5,4 & 4,4 & $-1,0$ & 1.3. & 0,3 & 3,0 & 1,3 & 0.4 & 2.8 & 7.8 & 59 & 9) & 25 & 13 & 52 & 10 \\
\hline & & 7,6 & 9,6 & 12.2 & 32.1 & 107.9 & 42.8 & 36.7 & 150,4 & 32,5 & 22.1 & 21.5 & 142.2 & 23.8 & 60.1 & 26,6 & 87,3 \\
\hline & \multicolumn{6}{|c|}{ PV Ts, eutro A mod, medka/mufto argBose PP (Moadura) } & & PV.10 & & & \multicolumn{2}{|c|}{ Número de pontos } & 17 & & & & \\
\hline \multirow[t]{3}{*}{$60-80$} & & 5.2 & 4.0 & -1.2 & 0.7 & 0.2 & 3.4 & 2.2 & 2.8 & 2.5 & 11,2 & 52 & 33 & 49 & 12 & 32 & 6 \\
\hline & & 9.1 & $10.4^{\top}$ & 11.8 & 28,9 ! & $104.3 !$ & 97.4 & 52,6 & $78,1^{\top}$ & 30,0 & $28.0^{\top}$ & 47.5 & 79.2 & 21.3 & $\overrightarrow{57.1}$ & $\overrightarrow{36.6}$ & $\overrightarrow{131.4}$ \\
\hline & \multicolumn{6}{|c|}{ PV Tb. A mod, texturs arenoss/medb on medib (Bagugr1) } & & PV-6 & & & \multicolumn{2}{|c|}{ Númerc de ponlos } & 13 & & & & \\
\hline \multirow[t]{3}{*}{0.25} & & 5,2 & 4.2 & $-1,0$ & 1.1 & 0.2 & 1.4 & 0.4 & 0.4 & 2.2 & 4.6. & 43 & 16 & 17 & 4 & 56. & 22 \\
\hline & & 7,5 & 6,7 & 19.5 & 45.6 & 94.7 & 56,9 & 81.6 & 93,1 & 36,3 & 30.2 & 40,1 & 87.9 & 34.5 & 69.4 & $20,2\}$ & 35.9 \\
\hline & \multicolumn{6}{|c|}{ PV Tb. A mod, texturs greaoss/mtdb on medb (Begugrf) } & & PV-6 & & & Nomero de & pontos & 14 & & & & \\
\hline $60-80$ & & 5,0 & 4.1 & $-0,9$ & 0.7 & 0,2 & 2.0 & 0.5 & 1.1 & 2.4 & 6,2 & 44 & 28 & 34 & 4 & 46 & 16 \\
\hline & & 11.7 & 6.5 & 27.7 & 28.1 & 140.9 & 58.5 & 69.4 & 73,3 & 40,5 & 20.5 & 53.2 & 75.1 & 13.7 & 75.3 & 13.0 & 41.5 \\
\hline & PV Tb,,$b_{1}$ & rupto, dstso & O OH Gllko, A & $A$ mod, med & dha/multo ar & Tribos (Sa) & ats Cras) & & & PV_.9 & Número de & ponios & 34 & & & & \\
\hline 0.25 & & 5,6 & 4.8 & -0.8 & 1.2 & 0,2 & 2.6 & 0,9 & 0.4 & 2,4 & 6,6 & 57 & 9 & 22 & 10 & 53 & 15 \\
\hline & & 10.4 & $13,1 \mid$ & 16.3 & 35.3 & 109.0 & 71,4 & 71,9 & 194,7 & 42,8 & 40.8 & 33.8 & 151.2 & 43.9 & 62,4 & 27.6 & 69.5 \\
\hline & PV Tb, 2bl & rupto, distro & O ou \&lkco, A & A mod, med & dha/matio or & rgBoos (Sor & nte Crus) & & & PV-9 & Número de $\mathrm{P}$ & pontos & 32 & & & & \\
\hline $60-80$ & & 5,3 & 4,3 & $-1,0$ & 0.7 & 0.2 & 3,1 & 1,2 & 1,5 & 3.0 & 9.0 & so & 25 & 50 & 7. & 35 & 9 \\
\hline & & 10.7 & 13,3 & 14.7 & 26,6 & 114.8 & 74,4 & 65.3 & 100,7 & 43,1 & 30,2 & 46,1 & 87.3 & 23,1 & 47.9 ! & 35.0 & 76.9 \\
\hline & PV A mod & ox proem, a & grenosa/me & edin (Ustos) & & & & PV-1 & & & Nomero de $\mathrm{P}$ & ponios & 4 & & & & 1 \\
\hline 0.25 & & 5.7 & 4.6 & $-1,1$ & 0,9 & 0.2 & 1,7 & 0.4 & 0.1 & 2.1 & 4.6 & $51 \mid$ & 5 & 14 & 7 & 60 & 20 \\
\hline & & 3.1 & 7,0 & 14,8 & 57.8 & 120,1 & 56.5 & 54,0 & 51.4 & 23,2 & 23,2 & 28.5 & 134,3 & 40.4 & 76,9 & 20,3 & 28.5 \\
\hline & PV A mod & ou proem, & grenos $2 / m t$ & tda (Using) & & & & PV-1 & & & Número de & ponios & 4 & & & & \\
\hline $60-80$ & & 5,5 & 4.3 & -1.1 & 0.5 & 0.1 & 1,6 & 0.3 & 1,1 & 1.6 & 4.6 & 43 & 35 & 25 & 11 & 51 & 13 \\
\hline & & 12,0 & 8,1 & 43.3 & 48.5 & 54.0 & 81,2 & 81.7 & 187,5 & 37,2 & 34.7 & 69.9 & 135,9 & 28.0 & 135,5 & 25,2 & 69.9 \\
\hline & grupamen & to tadbcrtm & trodo de $S$ & Solos Alurb & Is (A)̛́vio) & & & A & & & & & & & & & \\
\hline $0-25$ & & 5,1 & 4,2 & $-0,8$ & $0,9 \mid$ & 0.1 & 1,0 & 0.3 & 0,8 & 2,3 & 4,5 & 30.0 & 37.0 & 12,0 이 & 4.0 & 54,0 & 30 \\
\hline & & 9.8 & 9.3 & 22.7 & 43,8 & 685 & 53.3 & 83,7 & 70,9 & 39,5 & 27.6 & 58,1 & 65,9 & 23,5 & 61,3 & 19.0 & 37.4 \\
\hline & gгиранаев & to bodscrim & alnado de $\mathrm{S}$ & Solos Alurba & at (Alavio) & & & A & & & Número de & pontos & 10 & & & & \\
\hline $60-80$ & & 5.0 & 4.2 & $-0,9$ & 0.3 & 0,0 & 0.8 & 0.2 & 0,6 & 1,3 & 2,9 & 35 & 37 & 12! & 31 & 57 & 28 \\
\hline & & 6,2 & 3,8 & 27,5 & 51.6 & 87,4 & 66.6 & 73,6 & 57,6 & 36.8 & 19.6 & 52,8 & 64,0 & 36.0 & 67,1 & 27,4 & 46.4.] \\
\hline & Lnotko, st & str. sedim. & todbcrimin & agdo Grupo & o Pressadoks ( & (Irati) & & 14 & & & Número de & pontos & 23 & & & & \\
\hline 0.25 & & 5.7 & $4,7 !$ & $-1,0$ & 1,8 & 0,4 & 6,1 & 2,0 & 0,5 & 3,2 & 12.2 & 70 & 6 & 31 & 19 & 41 & 10 \\
\hline & & 10,5 & 13,7 & 19,8 & 39.6 & 88,5 & 86,5 & $73,7 \mid$ & 183.3 & 50,2 & 53.3 & 37.5 & 172,1 & 38,4 & 39,9 & $38.2\}$ & 68.5 \\
\hline & |LAtOlko, st & bsts. sedtin & tadkertento & agdo Grapo & Passadots & (Irati) & & L 13 & & & Número de & ponios & 7 & & & & \\
\hline $60-80$ & & 5,2 & 4,2 & $-1,0$ & 0,9 & 0,5 & 5.0 & 2,8 & 2.7 & 2.9 & 13,9 & 60 & 24 & 42 & 14 & 37 & 7 \\
\hline & & 8,2 ? & 10,5 & 21,5 & 65.5 & 103.5 & 50,0 & 94,1 & 166.1 & 37,4 & 66.5 & 16,5 & 95,5 & 41.5 & 34.6 & 46,3 & 71.0 \\
\hline & TR eutro o & o dstro, tes & x 1 ergobose & OU muHo ar & Ire. (Rstrutn & orada) & & TR & & & Número de $\mathrm{P}$ & pontos & 4 & & & & \\
\hline 0.25 & & 6,1 & 5,2 & $-0,9$ & $1,9]$ & 0,5 & 7,1 & $1,3 \mid$ & 0,1 & 3.1 & 12,0 & 74 & $1 \mid$ & 47! & $15 \mid$ & $27 \mid$ & 11 \\
\hline & & 2,7 & 7.4 & 37.8 & 50.9 & 127,9 & 55.5 & 52.6 & 200,0 & 19.3 & 37.4 & 11,0 & 200.0 & 26,2 & 49.0 & 24.4 & 59,5 \\
\hline & TR eutro o & o dstro, tes & xt arghose & ov multo ar & T. Rstrutn & brada) & & TR & & & Número de $\mathrm{p}$ & pontos & 12 & & & & \\
\hline $60-80$ & & 6,2 & 5.4 & $-0,8\}$ & 1.0 & 0.11 & 6.7 & 1,1 & 0,0 & 2.3 & 10,1 & 77 & 0 & 63) & 11 & 21 & 5 \\
\hline & & 10,1 & 7,0 & 29.9 & 48.1 & 129.0 & 115,3 & 209,5 & $97.3 \mid$ & 44,1! & 81,3 & 58,6 & 81.8 & 51.6 & 127,2 & 39.9 & 74,6] \\
\hline
\end{tabular}




\section{ANEXO 2}

Erodibilidade (K) Estimada das Unidades de Mapeamento de Piracicaba (SP) 


\begin{tabular}{|c|c|c|c|c|c|c|}
\hline \multirow[b]{3}{*}{ Camada } & & \multicolumn{2}{|l|}{ Valor de Erodibilidade (K) estimado } & \multirow[b]{2}{*}{ K medio } & \multirow[b]{2}{*}{ Cassificacão } & \multirow[b]{2}{*}{$\%$ ocorrência } \\
\hline & & $K(t h a h / h a M j ~ m m)$ & Classifincaçåo & & & \\
\hline & \multicolumn{2}{|c|}{ Unidade de mapeamento } & & & & \\
\hline \multirow[t]{2}{*}{$0-25$} & & $0,037698136 \mathrm{~A}$ & Alto & 0.0345 & Ano & 7,8 \\
\hline & \multicolumn{2}{|c|}{ A rela Quartzosa Podzélica Pouco Profunda } & & & & \\
\hline \multirow[t]{2}{*}{$60-80$} & & $0,031361432 N$ & Médio & & & \\
\hline & \multicolumn{2}{|c|}{ Areia Quartzosa Podzólica Pouco Profunda } & & & & \\
\hline \multirow[t]{2}{*}{$0-25$} & & $0,032733173 \mathrm{~A}$ & Alto & 0,0327 & Alto & \\
\hline & \multicolumn{2}{|c|}{ A reia Quartzosa Profunda Álica A moderado } & & & & \\
\hline & & & & & & \\
\hline \multirow[t]{2}{*}{$0-25$} & & $0,029439012 N$ & Médio & 0,0271 & Médio & 0,1 \\
\hline & \multicolumn{2}{|c|}{ Brunizem avermelhado, textura argilosa (Engenho) } & & & & \\
\hline \multirow[t]{2}{*}{$60-80$} & & $0,024823835 \Lambda$ & Médio & & $\cdot$ & \\
\hline & \multicolumn{2}{|c|}{ Brunizem avermelhado, textura argilosa (Engenho) } & & & & \\
\hline \multirow[t]{2}{*}{$0-25$} & & 0,040088291 & Alto & 0,0413 & Alto & 0,3 \\
\hline & \multicolumn{4}{|c|}{ grupamento indiscrivizado de Cambseolo Tb, A moderado, (Taquarexim) } & & \\
\hline & & & & & & \\
\hline \multirow[t]{2}{*}{$60-80$} & & $0,042560665 \mid A$ & Alto & & & \\
\hline & \multicolumn{4}{|c|}{ grupamento indiscriminado de Cambissolo Th, A moderado, (Taquarexim) } & & \\
\hline \multirow[t]{2}{*}{$0-25$} & & $0,036184463 \mid$ & Alto & 0,0308 & Médio & 0,2 \\
\hline & \multicolumn{2}{|c|}{ grupamento indiscriminado de Gleis Húmicos } & & & & \\
\hline \multirow[t]{2}{*}{$60-80$} & & 0,02549813 & Médio & & & \\
\hline & \multicolumn{2}{|c|}{ grupamento indiscriminado de Gleis Húmicos } & & & & \\
\hline \multirow[t]{2}{*}{$0-25$} & & 0,044626819 & Alto & 0,0402 & Alto & 1,6 \\
\hline & \multicolumn{2}{|c|}{ |grupamento indiscriminado de Gleis poaco Húmicos } & & & & \\
\hline \multirow[t]{2}{*}{$60-80$} & & $0,035777627 \mid$ & Alto & & & \\
\hline & \multicolumn{2}{|c|}{ grupamento indiscriminado de Gleis pouco Húmicos } & & & & \\
\hline $60-80$ & & 0,011217366 & Baixo & 0,0112 & Baixo & 1 \\
\hline & LR distroo & u álico, A húmico, muito argilosa (Nogueirs & ra) & & & \\
\hline $0-25$ & & 0,016147885 & Baixo & 0,0147 & Baixo & 3,3 \\
\hline & LR distroo & ú álico A moderado, argilosa (Barão Geral & aldo) & & & \\
\hline $60-80$ & & 0,01318896 & Baixo & & & \\
\hline & LR distro o & ou álico A moderado, argilosa (Barão Geral & aldo) & & & \\
\hline $0-25$ & & 0,012591996 & Baixo & 0,0122 & Baixo & 0,5 \\
\hline & LR eutro, $A$ & A mod, argilosa (Ribeirão Preto) & & & & \\
\hline
\end{tabular}




\begin{tabular}{|c|c|c|c|c|c|c|}
\hline \multirow[b]{3}{*}{ Camada } & & \multicolumn{2}{|l|}{ Valor de Erodibilidade (K) estimado } & \multirow[b]{2}{*}{ K médio } & \multirow[b]{2}{*}{ Classificaçăo } & \multirow[b]{2}{*}{$\%$ ocorrência } \\
\hline & & $\mathrm{h}(\mathrm{t}$ ha h/ha MJ mm) & Cassińcaça & & & \\
\hline & \multicolumn{2}{|c|}{ Unidade de mapeamento } & & & & \\
\hline \multirow[t]{2}{*}{$60-80$} & & $0.011738921 \mathrm{~B}$ & Baixo & & & \\
\hline & \multicolumn{2}{|c|}{ LR eutro, A mod, argiloss (Ribeirào Preto) } & & & & \\
\hline \multirow{2}{*}{$0-25$} & & 0,033680854 & Aho & 0,0328 & Aho & 2 \\
\hline & \multicolumn{2}{|c|}{ LV alica, Amoderado, text média (Coqueiro) } & & & & \\
\hline \multirow[t]{2}{*}{$60-80$} & & 0.031845994 & Alto & & & \\
\hline & \multicolumn{2}{|c|}{ LV álico, Amoderado, text média (Coqueiro) } & & & & \\
\hline \multirow[t]{3}{*}{$0-25$} & & $0,031682681 \perp$ & Médio & 0,0295 & Médio & 1,1 \\
\hline & \multicolumn{2}{|c|}{ LV álico A moderado, text média (Laranja Azeda) } & & & & \\
\hline & & . & & & & \\
\hline \multirow[t]{3}{*}{$60-80$} & & $0,027219465 \mathrm{~N}$ & Médio & & & \\
\hline & \multicolumn{2}{|c|}{ LV álico A moderado, text média (Laranja Azeda) } & & & & \\
\hline & & 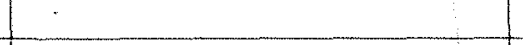 & & & & \\
\hline \multirow{3}{*}{$0-25$} & & 0,033209176 & Alto & 0,0321 A & Alto & 0,1 \\
\hline & \multicolumn{2}{|c|}{ LV álico. A proem, text média (T rês Barras) } & & & & \\
\hline & & 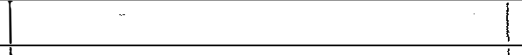 & & & & \\
\hline \multirow[t]{2}{*}{$60-80$} & & $0,031030129 \mid$ & Médio & & & \\
\hline & \multicolumn{2}{|c|}{ LV álico. A proem, text média (Três Barras) } & & & & \\
\hline \multirow[t]{3}{*}{$0-25$} & & 0,04134656 & Alto & $0,0392 \mid$ & Aho & 1 \\
\hline & \multicolumn{3}{|c|}{ LV Podzólico, A moderado, distro ou álico text média (Sảo Pedro) } & & & \\
\hline & & & & & & \\
\hline \multirow[t]{2}{*}{$60-80$} & & 0,037031293 & Alto & & & \\
\hline & \multicolumn{3}{|c|}{ LV Podzólico, A moderado, distro ou álico text média (São Pedro) } & & & \\
\hline \multirow[t]{2}{*}{0.25} & & 0,027773075 & Médio & 0,0256 & Médio & 1 \\
\hline & \multicolumn{3}{|c|}{ LV húmico álico, text média ou argilosa (Camarguintro) } & & & \\
\hline $60-80$ & & 0,02334433 & Baixo & & & \\
\hline & LVA húmic & co álico text media oa argilosa (Camarguin) & niro) & & & \\
\hline $0-25$ & & 0,022317794 & Baixo & 0,0199 & Baixo & 10 \\
\hline & LE álico A & moderado text argilosa (Limeira) & & & & \\
\hline & & & & & & \\
\hline $60-80$ & & 0,017466337 & Baixo & & & \\
\hline & LE álico A & moderado text argiloss (Limeira) & & & & \\
\hline & & & & & & \\
\hline $0-25$ & & 0,028197562 & Médio & 0,0254 & Médio & 0,2 \\
\hline & LE álico, A & moderado text argilosa (Santo Antonio) & & & & \\
\hline $60-80$ & & 0,022652346 & Baixo & & & \\
\hline & LE álico, $A$ & moderado text argilosa (Santo Antonio) & & & & \\
\hline & & & & & & \\
\hline
\end{tabular}




\begin{tabular}{|c|c|c|c|c|c|c|}
\hline & & \multicolumn{2}{|l|}{ Valor de Erodibilidade $(\mathrm{K})$ estimado } & \multirow[b]{2}{*}{ K médio } & \multirow[b]{2}{*}{ (Classificacho) } & \multirow[b]{2}{*}{$\%$ ocorréncia } \\
\hline & & $K($ ( ha h/ $\mathbf{m a ~ M} \mathbf{~ m m})$ & C. Tassif̂caç̃o & & & \\
\hline Camada & \multicolumn{2}{|c|}{ Unidade de mapeamento } & & & & \\
\hline \multirow[t]{2}{*}{0.25} & & $0.03198042 \mathrm{~A}$ & Alto & 0.0278 & Médio & 0.5 \\
\hline & \multicolumn{2}{|c|}{ LE álico A moderado text média (Hortolândia) } & & & & \\
\hline \multirow[t]{2}{*}{$60-80$} & & $0,023698973 \mathrm{~B}$ & Baixo & & & \\
\hline & \multicolumn{2}{|c|}{ LE álico A moderado text média (Hortolândia) } & & & & \\
\hline \multirow[t]{2}{*}{$0-25$} & & 0,047935875 & Alto & 0.0479 & Alto & 1,1 \\
\hline & Litossolo & & & & & \\
\hline \multirow[t]{2}{*}{$0-25$} & & 0,055349633 & Alto & 0,0582 & Alto & 3.1 \\
\hline & \multicolumn{2}{|c|}{ Litossolo substrato arenito Botucatu-Pirambóia } & & & & \\
\hline \multirow[t]{2}{*}{$60-80$} & & $0,061027671 \mid A$ & Alto & & & \\
\hline & \multicolumn{2}{|c|}{ Litossolo substrato arentto Botacatu-Pirambóia } & & & & \\
\hline & & & & & & \\
\hline \multirow[t]{2}{*}{$0-25$} & & $0,050916472 A$ & Alto & 0,0419 & Alto & 2,2 \\
\hline & \multicolumn{2}{|c|}{ Planossolo Ta, A moderado (Diamante) } & & & & \\
\hline & & & & & & \\
\hline \multirow[t]{2}{*}{$60-80$} & & 0,032825063 & Alto & & & \\
\hline & \multicolumn{2}{|c|}{ Planossoto Ta, A moderado (Diamante) } & & & & \\
\hline & & & & & & \\
\hline \multirow[t]{2}{*}{$0-25$} & & 0,033930059 & Alto & 0,0284 & Médio & 3,1 \\
\hline & \multicolumn{2}{|c|}{ PE Ta ou Tb, distro ou ácrico, argilosa, (Campestre) } & & & & \\
\hline \multirow[t]{2}{*}{$60-80$} & & 0,02293183 & Baixo & & & \\
\hline & \multicolumn{2}{|c|}{ PE Ta ou Tb, distro ou ácrica, argilosa, (Campestre) } & & & & \\
\hline & & & & & & \\
\hline \multirow[t]{2}{*}{$0-25$} & & $0,052951822 \mid A$ & Alto & 0,0482 & Alto & 23,4 \\
\hline & \multicolumn{3}{|c|}{ PV abrupto, álico, Amod, text arenosa/media (Serrinha) } & & & \\
\hline \multirow[t]{3}{*}{$60-80$} & & 0,043532657 & Alto & & & \\
\hline & PV abropto & , álico, Amod, text arenosa/média (Serrinhs & ha) & & & \\
\hline & & & & & & \\
\hline $0-25$ & & $0,029762141 \mid$ & Médio & 0,0267 & Médio & 0,8 \\
\hline & PV, distrón & ico ou álico, A mod, argilosa (Olaria) & & & & \\
\hline & & & & & & \\
\hline $60-80$ & & $0,023544913 \mid \mathrm{E}$ & Baixo & & & \\
\hline & PV, distróf & ico ou álico, A mod, argilosa (Olaria) & & & & \\
\hline $0-25$ & & 0,052580266 & Alto & 0,0438 & Alto & 1,5 \\
\hline & PV Ta, eutr & ro A mod, média/muito argilosa pp (Mandu & uca) & & & \\
\hline & & & & & & \\
\hline $60-80$ & & 0,035095103 & Alto & & & \\
\hline & PV Ta, eutr & ro A mod, média/muito argilosa Pp (Mandu & uca) & & & \\
\hline $0-25$ & & 0,045076631 & Alto & 0,0396 & Alto & 2,3 \\
\hline & PV Tb, A m & nod, textura arenosa/média ou média (Bagu & uari) & & & \\
\hline
\end{tabular}




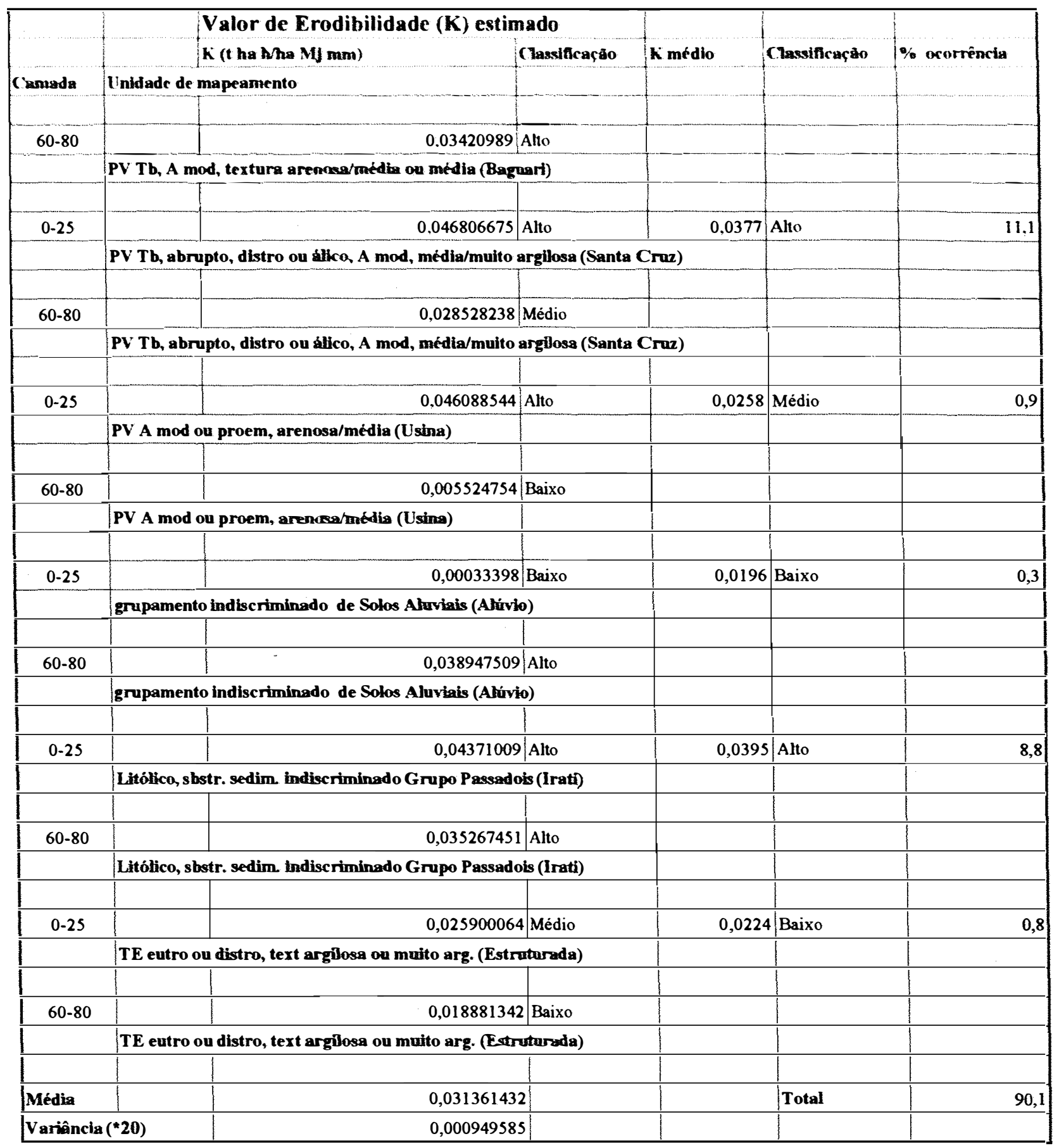




\section{ANEXO 3}

Detalhamento dos Sistemas de Manejo 
Anexo 3

\section{Sistemas de Manejo}

Sistema 1 a (cana de ano)

Construção de carreadores

Terraço em nível

Erradicador

Aração

Grade niveladora $(2 \mathrm{x}$ )

Plantio

Sistema 1 b (cana de ano)

Construção de carreadores

Terraço em nível

Erradicador

Calagem

Aração

Grade niveladora (2 $\mathrm{x})$

Plantio

Sistema 2 a (cana de aho)

Construção de carreadores

Terraço em nível

Calagem

Erradicador

Aração

Grade niveladora $(2 \mathrm{x})$

Plantio

Sistema 2 b (cana de ano)

Construção de carreadores

Terraço em nível

Erradicador

Aração

Grade niveladora (2x)

Plantio

Siatema 3 a (cana de ano e meio)

Construção dẹ carreadores

Terraço com gradiente

Herbicida (glif)

Calagem

Aração 
Grade niveladora (2x)

Herbicida (trifl.)

Adubação verde

Rolo faca

Plantio

Sistema 4 a (cana de ano e meio)

Construção de carreadores

Terraço em nível

Herbicida (glif)

Calagem

Aração

Grade niveladora $(2 \mathrm{x})$

Plantio

Sistema 5 a (cana de ano e meio)

Carreador

Terraço em nível

Herbicida (glif)

Calagem

Aração

Grade niveladora $(2 \mathrm{x})$

Plantio

Sistema 5 b (cana de ano e meio)

Carreador

Terraço em nível

Herbicida (glif)

Aração

Grade niveladora $(2 \mathrm{x})$

Plantio

Sistema 6 a (cana de ano e meio)

Carreador

Terraço com gradiente

Herbicida (glif)

Calagem

Aração

Grade niveladora $(2 \mathrm{x})$

Herbicida (triff.)

Adubação verde

Plantio 
Sistema 7 a (cana de ano e meio)

Carreador

Terraço em nível

Herbicida (glif)

Calagem

Aração

Grade niveladora (2 x)

Herbicida (trifl.)

Adubação verde

Rolo faca

Plantio

Sistema 8 a (cana de ano e meio)

Terraço com gradiente

Herbicida (glif)

Calagem

Aração

Grade niveladora (2x)

Herbicida (triflu)

Adubação verde

Rolo faca

Plantio

Sistema 9 a (cana de inverno)

Terraço em nível

Herbicida (glif)

Calagem

Aração

Grade niveladora (2 $\mathrm{x})$

Adubação verde

Rolo faca

Plantio

Irrigação

Sistema 10 a (cana de inverno)

Carreador

Terraço com gradiente

Calagem

Grade pesada

Grade niveladora (2 $\mathrm{x})$

Herbicida (trifl.)

Adubação verde

Rolo faca 
Plantio

Irrigação

Sistema 10 b (cana inverno)

Carreador

Terraço com gradiente

Grade pesada

Grade niveladora $(2 \mathrm{x})$

Herbicida (trifl.)

Adubação verde

Rolo faca

Plantio

Irrigação

Sistema 11 a (cana de inverno)

Terraço em nível

Aração

Calagem

Grade niveladora $(2 \mathrm{x})$

Herbicida (trifl.)

Adubação verde

Rolo faca

Plantio

Irrigação

Sistema 12 a (cana de inverno)

Carreador

Terraço com gradiente

Aração

Grade niveladora (2x)

Herbicida (trifl.)

Adubação verde

Rolo faca

Plantio

Irrigação

Sistema 12 b (cana de inverno)

Terraço com gradiente

Calagem

Aração

Grade niveladora (2x)

Herbicida (triflu)

Adubação verde 
Rolo faca

Plantio

Irrigação

Sistema 13 a (cana de inverno)

Carreador

Terraço com gradiente

Aração

Grade niveladora $(2 \mathrm{x})$

Herbicida (triff.)

Adubação verde e incorporação

Irrigação

Plantio

Sistema 13 b (cana de inverno)

Carreador

Terraço com gradiente

Calagem

Aração

Grade niveladora (2 x)

Grade niveladora

Herbicida (trifl.)

Adubação verde e incorporação

Irrigação

Plantio 


\section{ANEXO 4}

Cálculo do Potencial produtivo (tha) das

Unidades de Mapeamento 


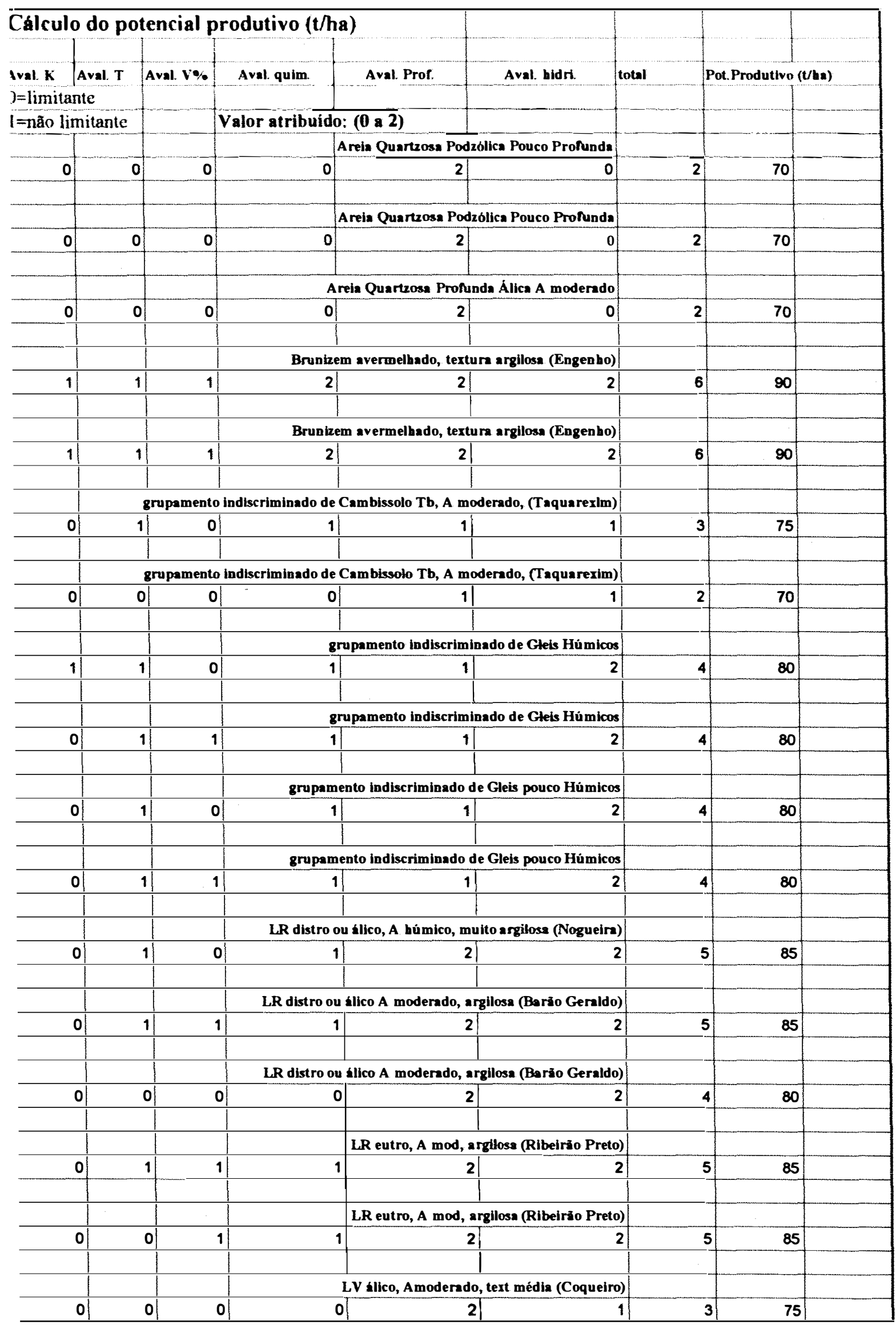




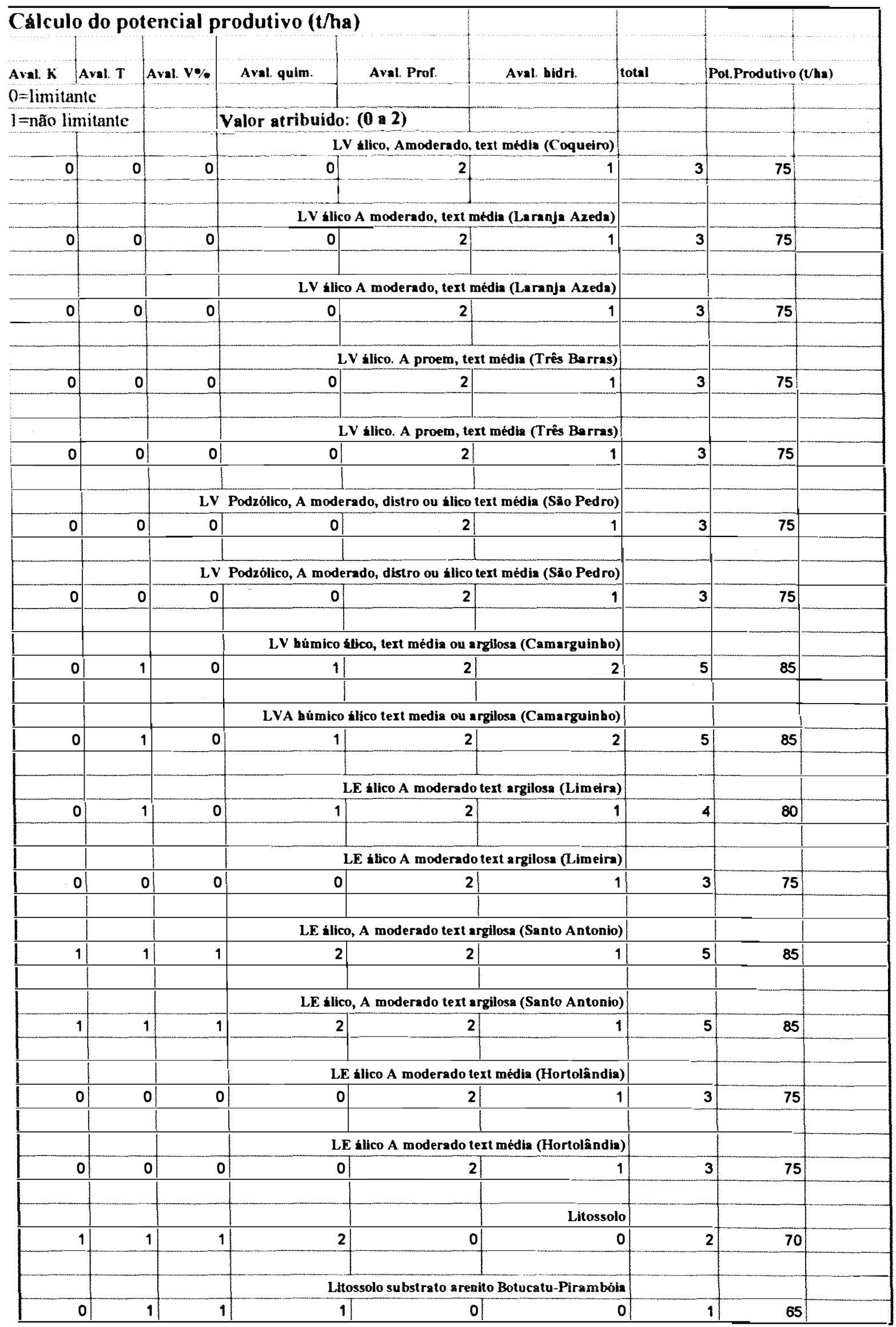




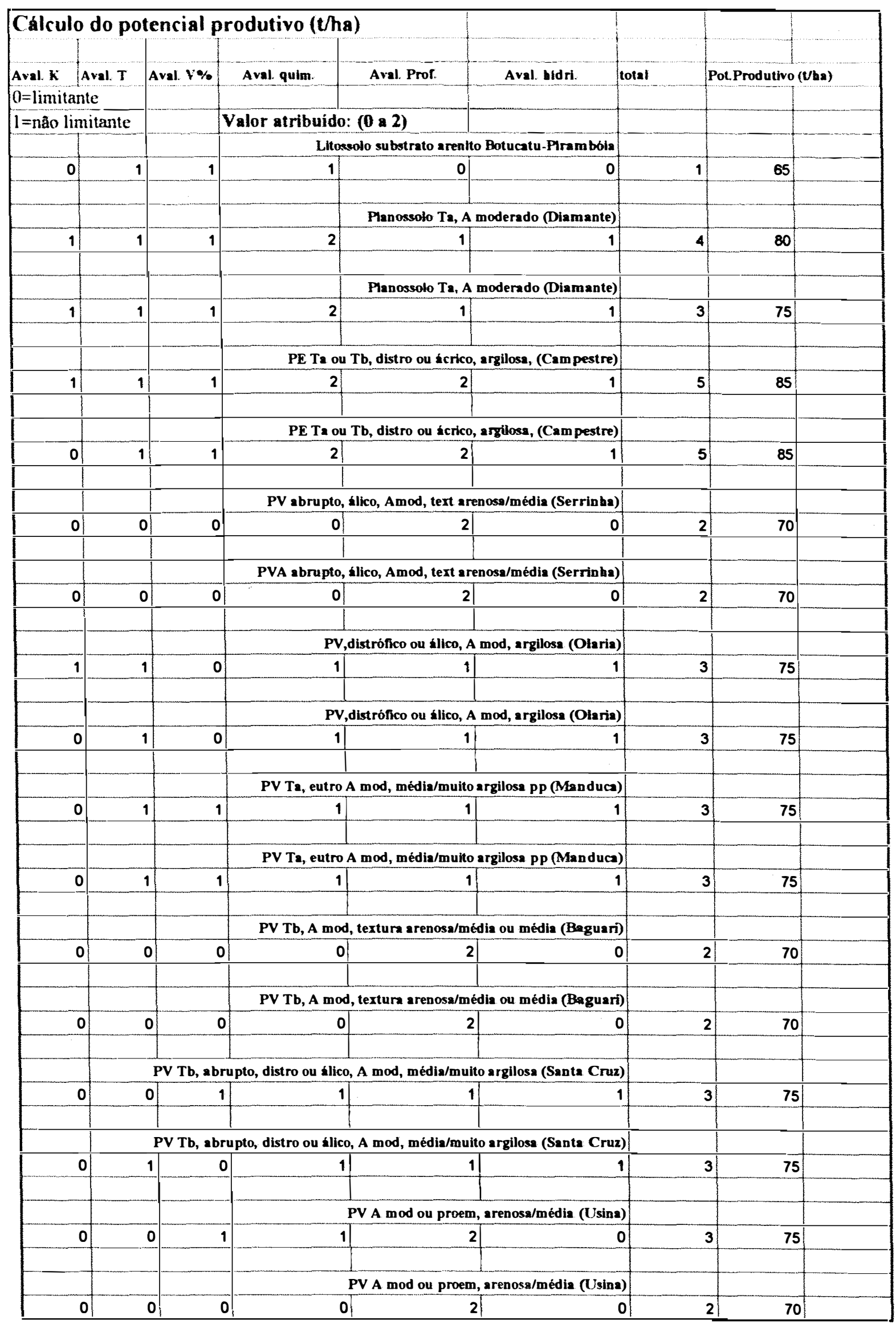




\begin{tabular}{|c|c|c|c|c|c|c|c|c|}
\hline \multicolumn{8}{|c|}{ Calculo do potencial produtivo (t/ha) } & \\
\hline Aval. $\mathrm{K}$ & Aval $\mathbf{T}$ & Aval V\% & Aval quim. & Aval. Pror: & Aval. Mldri. & \multirow[t]{2}{*}{ total } & \multicolumn{2}{|c|}{ Pol.Produtivo ( $(\mathrm{b})$} \\
\hline \multicolumn{8}{|c|}{$(0)=$ limitante } & \\
\hline \multicolumn{2}{|c|}{$1=$ nå limitante } & & \multicolumn{2}{|c|}{ Valor atribuido: $(0$ a 2) } & & & & \\
\hline & & & \multicolumn{3}{|c|}{ grupamento indiscriminado de Solos Aluviais (Alúvio) } & & & \\
\hline \multirow[t]{3}{*}{0} & 0 & 0 & 0 & 1 & 0 & 1 & 65 & \\
\hline & & & & & & & & \\
\hline & & & grupament & discriminado de S & Aluviais (Alúvio) & & & \\
\hline \multirow[t]{3}{*}{0} & 0 & 0) & 0 & $1]$ & 0 & 1. & 65] & \\
\hline & & & & & & & & \\
\hline & & & Ltólico, sbstr. sed & Indiscriminado G & o Passadois (Irati) & & & \\
\hline \multirow[t]{3}{*}{1} & 1 & 1 & 2 & 0 & 1 & 3 & 75 & \\
\hline & & & & & & & & \\
\hline & & & Litólico, sbstr. sed & . Indiscriminado G & o Passadois (Irati) & & & \\
\hline \multirow[t]{3}{*}{1} & 1 & 1 & 2 & $0]$ & 1 & 3 & 75 & \\
\hline & & & & & & & & \\
\hline & & & TE eutro ou distr & ext argillosa ou mui & arg. (Estruturada) & & & \\
\hline \multirow[t]{3}{*}{1} & 1 & 1 & 2 & 2 & 2 & 6 & 90 & \\
\hline & & & & & & & & \\
\hline & & & \multicolumn{3}{|c|}{ TE eutro ou distro, text argillosa ou muito arg. (Estruturada) } & & & \\
\hline 이 & 1 & 1 & 2 & 2 & 2 & 6 & 90 & \\
\hline
\end{tabular}


ANEXO 5

Cálculo do valor das operações 


\section{Valor das operações}

Critérios adotados:

Custo em dólares $(\mathrm{U} \$=0,9 \mathrm{R} \$)$

1. Construção e reparo de carreadores:

custo por ha: U\$ 8,44

Trator MF 292, V 128, com lâmina

* ORPLANA maio, 1995

2. Terraço em nível:

custo por ha: U\$27,48

(Associação dos fornecedores de cana de Piracicaba, abril 1995)

3. Terraço com gradiente e canal escoadouro:

Terraço embutido (Cat D6D/ acoplado) - custo por ha: U $\$ 32,94$

canaleta de escoamento (Cat D6D/ acoplado) - custo por ha: U\$4,12

plantio de grama e capim - custo por ha: U\$6,06

total: custo por ha: U\$43,12

*fonte: CONDE et al. 1994

4. Irrigação

Sistema de irrigação "Auto-propelido"

Irrigação suplementar com dotação de água de até $50 \mathrm{~mm}$ por mês, totalizando 150 $\mathrm{mm}$ por ano.

custo por ha: $U \$ 236,00$

*fonte: MATIOLI \& BARCELOS, 1994

5. Aplicação de herbicida

Trator $61 \mathrm{cv}$ rendimento $1 \mathrm{~h} / \mathrm{ha}$ (MARGARIDO et al. 1988)

Pulverizador 1 barra simples

custo por ha: U\$5,11 (IEA, fev 1995)

6. Herbicida:

5 litros Glifosate - custo por ha: U\$53,75 (IEA, fev 1995)

7. Grade Pesada

Trator $110 \mathrm{cv}$

grade ( $20 \times 26$ ") - rendimento $3 \mathrm{~h}$ /ha (MARGARIDO et al. 1988)

custo por ha: U\$27,48 (IEA, fev 1995)

8. Erradicador 
grade erradicadora (MF- 292/ v128)

custo por ha: U\$ 26,08 (ORPLANA maio 1995)

9. Subsolagem

Trator $110 \mathrm{cv}$ - rendimento $3 \mathrm{~h} / \mathrm{ha}$ (MARGARIDO et al. 1988)

custo por ha: U\$ 25,10 (IEA, fev 1995)

10. Aração

Trator $110 \mathrm{cv}$

Arado $4 \times 28^{n}$ - rendimento 3h/ha (MARGARIDO et al. 1988)

custo por ha: U\$ 26,38 (IEA, fev 1995)

11. Grade niveladora

Trator $110 \mathrm{cv}$

grade $28 \times 18^{n}$ - rendimento: $0,9 \mathrm{~h} / \mathrm{ha}$ (MARGARIDO et al. 1988)

custo por ha: U\$8,25 (IEA fev 1995)

12. Calagem

a.aplicação:

Trator $61 \mathrm{cv}+$ carreta - rendimento:0,83 h/ha (MARGARIDO et al. 1988)

custo por ha: U\$4,26 (IEA fev 1995)

b.insumo:

4 toneladas de calcário dolomítico

custo por ha: U\$ 54,29 (IEA fev 1995)

13. Grade niveladora

Trator $110 \mathrm{cv}$

grade $28 \times 18^{n}$ - rendimento: $0,9 \mathrm{~h} / \mathrm{ha}$ (MARGARIDO et al. 1988)

custo por ha: U\$8,25 (IEA fev 1995)

14 herbicida

a. aplicação

custo por ha: U\$ 5,11 (Idem item 6)

b. herbicida

2 litros de trifluralin: custo por ha: U\$ 12,32 (IEA, fev 1995)

15. Adubação verde

Plantio

Trator $61 \mathrm{cv}$

plantadeira adubadeira de quatro linhas - rendimento1,52 h/ha (MARGARIDO et al.

1988) 
custo por ha: U\$7,78 (IEA, fev 1995)

Semente: $20 \mathrm{~kg}$ de crotalária (Crotalaria juncea) por ha custo por ha: U\$ 36,00 (Pirahy sementes)

16. Rolo faca

Trator $110 \mathrm{cv}$

(= grade $\left.28 \times 18^{\prime \prime}\right)$ rendimento $0,9 \mathrm{~h} /$ ha (MARGARIDO et al. 1988)

custo por ha: U\$ 8,15 (IEA, fev 1995)

17 Plantio

* igual para todos os sistemas de manejo

sulcação e adubação

- distribuição de mudas (carreta)

- cobertura mecânica de mudas

custo por ha: U\$103,63 (Centro de pesquisas Agrícolas-CEPEA- FEALQ)

Mão de obra

distribuição de mudas

- picação de mudas

- repasse e cobertura de mudas

custo por ha: U\$32,04 (Centro de pesquisas Agrícolas-CEPEA- FEALQ)

18. Fertilizante plantio

* igual para todos os sistemas de manejo

$450 \mathrm{~kg} / \mathrm{ha}$ 4-20-20 (MARGARIDO et al. 1988)

custo por ha: U\$94,81 (IEA, fev 1995)

19. Mudas

* igual para todos os sistemas de manejo

10 t/ha (MARGARIDO et al. 1988) + frete (Centro de pesquisas Agrícolas-CEPEAFEALQ)

custo por ha: U\$ 153,11

20. Tratos culturais

* igual para todos os sistemas de manejo

Aplicação de herbicida custo por ha: U\$ 5,11 (IEA, fev 1995)

herbicida: Gesapax 500 (2 1/ha - U\$11,93)+ Combini $(2$ 1/ha- U\$46,59)

(Associação dos fornecedores de cana de Piracicaba, abril 1995)

custo por ha: U\$63,63

21. cultivo e adubação de cobertura 
* igual para todos os sistemas de manejo

Trator $110 \mathrm{cv}$ -

supercultivador triplice - rendimento $1,5 \mathrm{~h} / \mathrm{ha}$ (MARGARIDO et al. 1988)

custo por ha: U\$ 14,74 (IEA, fev 1995)

21.Fertilizante: opçð̃es

$500 \mathrm{~kg}$ 14-7-28 custo por ha: U\$ 112,18 (IEA, fev 1995)

- $500 \mathrm{~kg}$ 20-5-20 custo por ha: U\$113,72 (IEA, fev 1995)

- $200 \mathrm{~kg}$ de sulfato de amônia $+100 \mathrm{~kg}$ cloreto de potássio.

Custo por ha: U\$60,6 (IEA, fev 1995)

22. Colheita e transporte

* igual para todos os sistemas de manejo

Queima $4 \mathrm{~h} / \mathrm{ha}$. Custo por hora 0,89 (mão de obra) custo por ha: U\$ 3.55

- corte $1,15 \mathrm{~h} / \mathrm{t}$ Custo por hora 0,89(mão de obra)

custo por ha: U\$ $(1,15$ x Produção $(t)$ x 0,89$)$

Carregamento: custo por ha: U\$80,97

- Transporte: custo por ha: U\$ 121,21

* fonte: (Centro de pesquisas Agrícolas-CEPEA- FEALQ) 


\section{ANEXO 6}

Cálculo das despesas relativas aos

Sistemas de Manejo 


\begin{tabular}{|c|c|c|c|c|c|c|c|c|c|c|c|}
\hline \multirow{2}{*}{\multicolumn{12}{|c|}{$\mid 10$}} \\
\hline & & & & & & & & & & & \\
\hline \\
\hline \multicolumn{3}{|c|}{$\frac{\text { Operacoes roferentes a cada Sisterne de Manejo }}{\text { Sistemas de manejo }}$} & \multirow{2}{*}{$\frac{1}{A}$} & \multirow{2}{*}{$\begin{array}{l}1 \\
\end{array}$} & \multirow{2}{*}{$\frac{2}{A}$} & \multirow{2}{*}{$\frac{2}{B}$} & \multirow{2}{*}{$\frac{3}{A}$} & \multirow{2}{*}{$\frac{4}{A}$} & \multirow{2}{*}{$\frac{5}{A}$} & \multirow{2}{*}{$\frac{5}{B}$} & \multirow{2}{*}{$\frac{6}{6}$} \\
\hline cana plarta & & & & & & & & & & & \\
\hline Operaçoes & & $\mid x$ & 5,8 & 3,5 & 7,1 & 2,6 & $8.1 \mid$ & 1,8 & 3,21 & 2,2 & 5,4 \\
\hline & & |ares total (ha) & $10215.98 \mid$ & $6164,81 \mid$ & $12505.76 \mid$ & 4579.58 & $14267,14 \mid$ & 3170.48 & 5636.40 & 3875,03 & 9511.43 \\
\hline const reparo is & Do correadores & $(U: 8,44 / \mathrm{ha})$ & 8.44 & 8.44 & 8,44 & 8.44 & 8.44 & 8.44 & 8.44 & 8,44 & 8,44 \\
\hline plan. conser. If & Iterraço nivel & (U.527.48 ha) & 27,48 & 27,48 & 27,48 & 27.48 & & 27,48 & 27,48 & 27.48 & \\
\hline & ft.grad.+c.esc. & (Ust3.12/ ha) & & & & & 43.12 & & L & & 43,12 \\
\hline & |lrrigaçato & (us:36/ ha) & & & & & & $I$ & $L$ & L & \\
\hline herbicida & |apllcaçä & (U: 5,11/ha) & & & & & 5.11 & 5.11 & 5,11 & 5,11 & 5,11 \\
\hline & Therb. (5/ glifo.) II & (U:553,75/ ha) & & & & & 53,75 & 53,75 & 53,75 & 53,75 & 53,75 \\
\hline preporo solo: & lorade pesada & (U:227,48/ ha) & & & & & & 1 & 1 & 1 & \\
\hline & lerradicador & (Us:26,08/ ha) & 26,08 & 26,08 & 26,08 & 26,08 & & & & 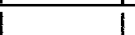 & \\
\hline & |subsolagem & (1) & & & & & & & & 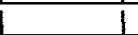 & \\
\hline & Jaref̧a & (I):26,38/m) & 26.38 & 26,38 & 26,38 & 26.38 & 26,38 & 26,38 & 26,38 & 26,38 & 26,38 \\
\hline & Igrade nivel. & (U:8,25/ ha) & 8,25 & 8,25 & 8,25 & 8,25 & 8,25 & 8,25 & 8,25 & 8,25 & 8,25 \\
\hline calagem & Taplicaça & I(US4,26/ ha) & & 4,26 & 4,26 & & 4.26 & 4,26 & 4,26 & $\perp$ & 4,26 \\
\hline & IInsumo (4t) & (1) & & 54,29 & 54,29 & & 54,29 & 54,29 & 54,29 & 1 & 54,29 \\
\hline & Tgrade nlvel. & (UR:8,25/ ha) & 8,25 & 8,25 & 8,25 & 8,25 & 8,25 & 8,25 & 8.25 & 8,25 & 8,25 \\
\hline herticica & Taplicaça & I(LAs,11/ha) & & & & & 5,11 & 1 & & $\perp$ & 5,11 \\
\hline & Therb. $(2 \mid$ toinu.) & (U:\$12,32 ha) & & & & & 12,32 & 1 & & $\perp$ & 12,32 \\
\hline adub verde & Iplantio & I(U:37,78/ma) & & & & & 7,78 & & & 1 & 7,78 \\
\hline & |semente $(20 \mathrm{~kg}) \quad 11$ & I(US36/ra) & & & & & 36 & 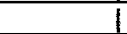 & & 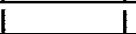 & 36 \\
\hline & |roloface & I(Us;8,15/ ha) & & & & & 8,15 & 1 & & L & 8,15 \\
\hline Plantio & |mecanizaçà & (uss103,63/ ha) & $103, \mathbb{3}$ & 103,63 & 103,63 & 103,63 & 103,63 & 103,63 & 103,63 & $103, \sqrt[3]{3}$ & 103,63 \\
\hline & Imæo de obra & (Lses2,04/ha) & 32,04 & 32,04 & 32,04 & 32,04 & 32,04 & 32,04 & 32,04 & 32,04 & 32,04 \\
\hline & Tadubo & (I) $(\sin 8,81 / \mathrm{ha})$ & 94,81 & 94,81 & 94,81 & 94,81 & 94,81 & 94,81 & 94,81 & 94,81 & 94,81 \\
\hline & Trudes & (US153,11/ha) & 153,11 & 153,11 & 153,11 & 153,11 & 153,11 & 153,11 & 153,11 & 153,11 & 153,11 \\
\hline liratos & Forplice oper. & (Us:14,74/ ha) & 14,74 & 14,74 & 14,74 & 14,74 & 14,74 & 14,74 & \begin{tabular}{l|l|}
14,74 \\
\end{tabular} & 14,74 & $\begin{array}{l}14,74 \\
\end{array}$ \\
\hline celturals & Tadubo & I(U:A113,72/ ha) & 113,72 & 113,72 & 113,72 & 113,72 & 113,72 & 113,72 & 113,72 & 113,72 & 113,72 \\
\hline 1 & Therticida & (1) & 63,63 & 63,63 & 63,63 & 63,63 & 63,63 & డె, & $\sqrt[3,63]{6}$ & 63,63 & $\mathbb{6 , 6 3}$ \\
\hline 7 & |capinas & I(U:25,65) & 25,65 & 25,65 & 25,65 & 25,65 & 25,65 & 25,65 & 25,65 & 25,65 & 25,65 \\
\hline & total das operaçbel & (Us/área) & 706,21 & 764,76 & 764,76 & 706,21 & 882,54 & 797,54 & 797,54 & 738,99 & 882,54 \\
\hline & T Prod. media & (t/ma) & 80 & 80,5 & 79 & 81,5 & 78 & 80 & 78,5 & 86 & 71,5 \\
\hline & & & & & & & & & L & 1 & \\
\hline T & & & & & & & & & L & 1 & \\
\hline & & & & & & & & & 1 & 1 & L \\
\hline & & & & & & & & & 1 & $\perp$ & 1 \\
\hline I & 1 & & & & & & & & 1 & 1 & 1 \\
\hline & Sistemas de manejo & & 1 & 1 & 2 & 2 & 3 & 4 & 5 & 5 & 6 \\
\hline & & & A & B & A & B & A & A & A & B & A \\
\hline cana soca & & & & & & & & & 1 & 1 & 1 \\
\hline tratos culturai & i I triplice oper. & (US:14,74/ ha) & 14,74 & 14,74 & 14,74 & 14.74 & 14,74 & 14,74 & 14,74 & 14,74 & 14,74 \\
\hline & ladubo & (IU:1113,72/ he) & 113,72 & 113,72 & 113,72 & 113,72 & 113,72 & 113,72 & 113,72 & 113,72 & 113,72 \\
\hline & Therbicida & |(US63,63/ha) & $6, \sqrt[3]{3}$ & 63,63 & 63,63 & 6,63 & $\sqrt[6,63]{1,6}$ & డ3,డ3 & డ3,డ3 & డె, -3 & 63,63 \\
\hline & |caplnas & I(U:25,65) & 25,65 & 25,65 & 25,65 & 25,65 & 25,65 & 25,65 & 25,65 & 25,65 & 25,65 \\
\hline & Total & I (UEJ/Area) & 217,74 & 217,74 & 217,74 & 217,74 & 217,74 & 217,74 & 217,74 & 217,74 & 217,74 \\
\hline & & & & & & & & & & 1 & 1 \\
\hline & & & & & & & & & $\perp$ & 1 & 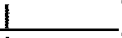 \\
\hline & & & & & & & & & $\perp$ & 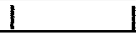 & 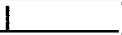 \\
\hline & & 1 & & & & & & & 1 & 1 & 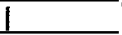 \\
\hline & Sistemas de manejo & & 1 & 1 & 2 & 2 & 3 & 4 & 5 & 5 & 6 \\
\hline Coltreits & & & A & B & $\mathbf{A}$ & B & A & $\mathbf{A}$ & $\mathbf{A}$ & B & A \\
\hline I. & |(totel por corte) & & & & & & & & & & $\perp$ \\
\hline & queima & f(US 3,55/20) & 3.55 & 3,55 & 3,55 & 3,55 & 3,55 & 3,55 & 3,55 & 3,55 & 3,55 \\
\hline & Forie & $\|\left(U_{3881,88 / h a)}\right.$ & 81,88 & 82,39 & 80,86 & 83,42 & 79,83 & 81,88 & 80,34 & 88,02 & 73,18 \\
\hline & |carregamento & f(Us:80,97/ ha) & 80,97 & 80,97 & $80 ; 97$ & 80,97 & 80,97 & 80,97 & 80,97 & 80,97 & 80,97 \\
\hline & |Transporte & fus 121,21/(km) & 121.21 & 121,21 & 121,21 & 121,21 & 121,21 & 121,21 & 121,21 & 121,21 & 121,21 \\
\hline & Total & (1ख/ha) & 287,61 & 288,12 & 286,59 & 289,15 & 285,56 & 287,61 & 286,07 & 293,75 & 278,91 \\
\hline & 1 & 1 & & & 1 & & 1 & 1 & 1 & 1 & 1 \\
\hline
\end{tabular}




\begin{tabular}{|c|c|c|c|c|c|c|c|c|c|c|c|c|}
\hline \multicolumn{13}{|c|}{ Operacoes reforentes a cado Sistema de Manejo } \\
\hline \multicolumn{3}{|c|}{ Sistorras de manejo } & 7 & 8 & 9 & 10 & 10 & 11 & 12 & 12 & 13 & 13 \\
\hline cana plartal & & & A & $\mathbf{A}$ & $\mathbf{A}$ & $\mathbf{A}$ & $\mathbf{B}$ & A & A & $\mathbf{B}$ & A & $\mathbf{B}$ \\
\hline \multirow[t]{2}{*}{ Operaçoes } & & $\overline{1 \%}$ & 3,7 & 19,1 & 2,4 & 0,8 & 0.3 & 0,8 & 1,5 & 15,3 & $5,9 \mid$ & 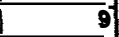 \\
\hline & & Itrea totol (ha) & $6517,09 \mid$ & $33642.26 \mid$ & 4227,30 & $1585,24 \mid$ & 528,41 & 1409,10 & 2642.06 & 26949.04 & 10392,11 & 15852.38 \\
\hline constr repe /c & ide carreadures il & $(U \leq 8,4 / \mathrm{ha})$ & 8.44 & 8,44 & 8,44 & 8,44 & 8,44 & 8,44 & 8,44 & 8.44 & 8,44 & 8,44 \\
\hline \multirow[t]{3}{*}{ plan. conse } & terraço nivel & (U:527.48 ha) & 27.48 & & 27.48 & & & 27,48 & I & 1 & 1 & 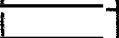 \\
\hline & L.grad.tc.esc. & (10543.12/ ha) & & 43.12 & & 43,12 & 43,12 & & 43,12 & 43,12 & 43,12 & 43,12 \\
\hline & Irrigaçio & (US236/ ha) & & & 236 & 236 & 236 & 236 & 236 & 236 & 236 & 236 \\
\hline \multirow[t]{2}{*}{ herbicida } & aplicaçalo & (U: 5,11/ha) & 5,11 & 5,11 & 5,11 & & & 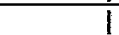 & & & & 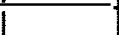 \\
\hline & herb. (5 I gifa) & (U5,53,75/ ha) & 53,75 & 53,75 & 53,75 & & & 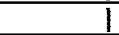 & & 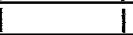 & 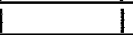 & 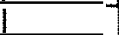 \\
\hline \multirow{5}{*}{ prepero sol } & grade pasada & (US27,48/ha) & & & & 27.48 & 27,48 & & & & L & 1 \\
\hline & lerredicador & (4) & & & & & & & & 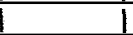 & i & i \\
\hline & |subsolegem & 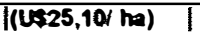 & & & & & & & 1 & 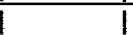 & 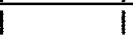 & $\mid$ \\
\hline & Iaraç»o & (US26,38/ha) & 26,38 & 26,38 & 26,38 & & & 26,38 & 26,38 & 26,38 & 26,38 & 26,38 \\
\hline & grade nivel. & l(Us8,25/ha) & 8.25 & 8,25 & 8.25 & 8,25 & 8,25 & 8.25 & 8,25 & 8,25 & 8,25 & 8,25 \\
\hline \multirow[t]{3}{*}{ calagem } & |aplicaçäo & (LS4,26/ ha) & 4,26 & 4,26 & 4,26 & 4,26 & & 4,26 & & 4,26 & 1 & 4,26 \\
\hline & Insurmo (4t) & (U554,29/ha) & 54,29 & 54,29 & 54,29 & 54,29 & & 54,29 & & 54,29 & 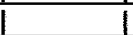 & 54,29 \\
\hline & |grade nivel. & (URAB,25/ ha) & 8,25 & 8,25 & 8.25 & 8,25 & 8,25 & 8.25 & 8,25 & 8,25 & 8,25 & 8,25 \\
\hline \multirow{2}{*}{\begin{tabular}{|l|} 
herbicida \\
\end{tabular}} & Iapliceçəo & (U:S5,11/ha) & 5,11 & 5,11 & 5,11 & 5,11 & 5,11 & 5,11 & 5,11 & 5,11 & 5,11 & 5.11 \\
\hline & Therb.(2 I trthu.) | & (US12,32/ha) & 12,32 & 12,32 & 12,32 & 12,32 & 12,32 & 12,32 & 12,32 & 12,32 & 12,32 & 12,32 \\
\hline \multirow{3}{*}{\begin{tabular}{|c|} 
adub. verde \\
\end{tabular}} & Dlantio & (U:57,78/na) & 7.78 & 7,78 & 7,78 & 7,78 & 7,78 & 7,78 & 7,78 & 7,78 & 7,78 & 7.78 \\
\hline & semente $(20 \mathrm{~kg})$ | & I(U536/50) & 36 & 36 & 36 & 36 & 36 & 36 & 36 & 36 & 36 & 36 \\
\hline & Irolo faca & (US:8,15/ ha) & 8,15 & 8,15 & 8.15 & 8,15 & 8,15 & 8,15 & 8,15 & 8,15 & 8,15 & 8,15 \\
\hline \multirow[t]{4}{*}{ plantio } & Imecanlzaç»o & (US103,63/ ha) & 103,63 & 103,63 & 103,03 & 103,63 & 103,63 & 103,63 & $103, \mathbb{3}$ & 103,03 & 103,63 & 103,63 \\
\hline & mato de obra & (U:332,04/ ha) & 32,04 & 32,04 & 32,04 & 32,04 & 32,04 & 32,04 & 32,04 & 32,04 & 32,04 & 32,04 \\
\hline & padubo & (US94,81/ ha) & 94,81 & 94,81 & 94,81 & 94,81 & 94,81 & 94,81 & 94,81 & 94,81 & 94,81 & 94,81 \\
\hline & I mudas & f(US153,11/ha) & 153,11 & 153,11 & 153,11 & 153,11 & 153,11 & 153,11 & 153,11 & 153,11 & 153,11 & 153,11 \\
\hline tratos & Itriplice oper. & (US14,74/ ha) & 14,74 & 14,74 & 14,74 & 14,74 & 14,74 & 14,74 & \begin{tabular}{l|l|}
14,74 \\
\end{tabular} & 14,74 & 14,74 & 14,74 \\
\hline \multirow[t]{10}{*}{ culturais } & ladubo & (IU:A(113,72/ ha) & 113,72 & 113,72 & 113,72 & 113,72 & 113,72 & 113,72 & 113,72 & 113,72 & 113,72 & 113,72 \\
\hline & Therticida & (U563,63/ ha) & $\widetilde{3,63}$ & 63,63 & $\mathbb{6 3 , 6 3}$ & $\widetilde{3,63}$ & 63,63 & 6,63 & 6,63 & 63,63 & 63, & (6,63 \\
\hline & |capinas & i(U:25,65) & 25,65 & 25,65 & 25,65 & 25,65 & 25,65 & 25,65 & 25,65 & 25,65 & 25,65 & 25,65 \\
\hline & bol das operaço & (Usłárea) & 866.9 & 882,54 & 1102,9 & 1060,78 & 1002,23 & 1044,04 & 1001,13 & 1059,68 & 1001,13 & 1059,68 \\
\hline & Prod. media & (tha) & 70 & 76 & 70 & 73 & 75 & 71 & 75 & 66 & 72,5 & 67,5 \\
\hline & & & & & & & & & & I & 1 & 1 \\
\hline & & & & & & & & & & 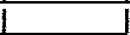 & 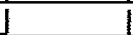 & 1 \\
\hline & & & & & & & & & & & 1 & 1 \\
\hline & & & & & & & & & & & & 1 \\
\hline & & & & & & & & & & 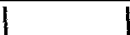 & 1 & 1 \\
\hline \multicolumn{3}{|c|}{ Sistemas de manejo } & 7 & 8 & 9 & 10 & 10 & 11 & 12 & 12 & 13 & 13 \\
\hline & & & $\bar{A}$ & $\bar{A}$ & $\bar{A}$ & $\bar{A}$ & B & $\bar{A}$ & $\mathbf{A}$ & B & $\mathbf{A}$ & B \\
\hline cana soce & & & & & & & & & & 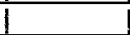 & 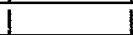 & 1 \\
\hline \multirow[t]{9}{*}{ |tratos cultu } & |triplice oper. & (US14,74/ ha) & 14,74 & 14,74 & 14,74 & 14,74 & 14,74 & 14,74 & 14,74 & 14,74 & 14,74 & 14,74 \\
\hline & Iadubo & |(U્ज113,72 ha) & 113,72 & 1113,72 & 113,72 & 113,72 & 113,72 & 113,72 & 113,72 & 113,72 & 113,72 & 113,72 \\
\hline & Therbicida & f(U563,63/ ha) & $\mathbb{6 , \mathbb { 3 }}$ & 63,63 & [3,63 & డె, డ3 & డె, & డ3,63 & $\mathbb{6 , \mathbb { 3 }}$ & [3, & డ3, & 63,63 \\
\hline & |capinas & $f(4: 25,65)$ & 25,65 & 25,65 & 25,65 & 25,65 & 25,65 & 25,65 & 25,65 & 25,65 & 25,65 & 25,65 \\
\hline & Total & (U:łárea) & 217,74 & 217,74 & 217,74 & 217,74 & 217,74 & 217,74 & 217,74 & 217,74 & 217,74 & 217,74 \\
\hline & & & & & & & & & & 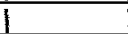 & 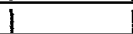 & 1 \\
\hline & & & & & & & & & 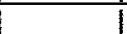 & 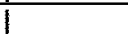 & $\frac{1}{4}$ & 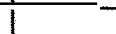 \\
\hline & & & & & & & & & 1 & 1 & 1 & 1 \\
\hline & & & & & & & & & & & & I \\
\hline & Sistemes de mane & & 7 & 8 & 9 & 10 & 10 & 11 & 12 & 12 & 13 & 13 \\
\hline Colheita & & 1 & A & $\mathbf{A}$ & $\mathbf{A}$ & A & B & $\mathbf{A}$ & $\mathbf{A}$ & B & A & B \\
\hline I. & f(total por corte) & & & & & & & & & & 1 & 1 \\
\hline & qqueims & (US 3,55/ha) & 3,55 & 3,55 & 3,55 & 3,55 & 3,55 & 3,55 & 3,55 & 3,55 & 3,55 & 3,55 \\
\hline & corte & (US:81,88/ ha) & 71,65 & 77,79 & 71,65 & 74,72 & 76,76 & 72,67 & 76,76 & 67,55 & 74,20 & 69,09 \\
\hline & carregamento & (ILs80,971 ha) & 80,97 & 80,97 & 80,97 & 80,97 & 80,97 & 80,97 & 80,97 & 80,97 & 80,97 & 80,97 \\
\hline & |Transporte & (US 121,21/km) & 121,21 & 121,21 & 121,21 & 121,21 & 121,21 & 121,21 & 121,21 & 121,21 & 121,21 & 121,21 \\
\hline & Total & (U5/30) & 277,38 & 283,52 & 277,38 & 280,45 & 282,49 & 278,40 & 282,49 & 273,28 & 279,93 & 274,82 \\
\hline & 1 & & & & & & & & & & & \\
\hline
\end{tabular}




\section{ANEXO 7}

Índices relativos aos Sistemas de Manejo 


\section{Descrição dos índices relativos ao sistemas de manejo}

coluna 1: Produtividade média esperada referente ao sistema de manejo (t/ha).

coluna 2: Despesas em US/ha ano: todas as operaçð̃es incluídas: plantio +5 tratos culturais +5 colheitas dividido por 5 .

coluna 3: Receita total em US/ha ano: Produtividade (col 1) multiplicada por US 11,5 (preço considerado por tonelada de cana).

coluna 4: Margem bruta em US/ha ano: margem bruta dos ha em produção por ano (receita (col 3) despesas ( $\mathrm{col} 2)$.

coluna 5: Área em ha : área referente ao sistema de manejo em ha.

coluna 6: Área total: área acumulada referente ao sistema de manejo (área do sistema em questão + somatória das áreas anteriores.

coluna 7: Idem a coluna $6 \mathrm{em} 1000$ ha.

coluna 8: Área em produção efetiva em 1000 ha: Área total para sistemas la a 2b (cana de ano). 5/6 da área total para sistemas 3a a 13b (cana de ano e meio e cana de ano com plantio no inverno) coluna 9: Área em produção efetiva acumulada em 1000 ha: área em produção efetiva do sistema (coluna 8) + somatória das áreas dos sistemas anteriores.

coluna 10: Produção total em $1000 \mathrm{t}$ por ano: área sob produção (coluna 8) multiplicada pela produtividade media esperada dos sistema (clouna 1).

coluna 11: Produção total acumulada em 1000 t: produção total referente ao sistema de manejo (coluna 10) + somatória das produç̃es dos sistemas anteriores.

coluna 12: Margem bruta referente ao sistema de manejo (1000 US): margem bruta por ha (col 4) multiplicada pela área em produção correspondente ao sistema de manejo ( $c 0 l$ 8).

coluna 13: Margem bruta total acumulada em 1000 US: margem bruta referente ao sistema de manejo (col 12) + somatória das margens brutas dos sistemas anteriores.

coluna 14: Margem bruta em US por ha total por ano: Margem bruta total referente ao sistema de manejo (col 12) dividida pela área total ( $c 017)$.

coluna 15: Área total de produção em 1000 ha referente ao cenário 1: somatória das áreas em 1000 ha (col 9) referentes aos sistemas de manejo incluídos no cenário.

coluna 16: Produção total em $1000 \mathrm{t}$ referente ao cenário. somatória das produçð̃es em $1000 \mathrm{t}$ (col 10) dos sistemas de manejo incluídos no cenário.

coluna 17: Margem bruta média referente ao cenário em US por ha por ano: média ponderada das margens brutas ( $\mathrm{col} 14$ ) de cada cenário pela sua área de ocorrência (coluna 7).

coluna 18: Margem bruta total em 1000 US referente ao cenário: somatória das margens brutas totais (col 12) dos sistemas de manejo incluídos nos cenários. 


\begin{tabular}{|c|c|c|c|c|c|c|c|c|c|c|c|}
\hline & & & Valores rela & itivos a0s sist & stemas de ma & nejo & & & & & \\
\hline & & 1 & 2 & 3 & 4 & 6 & 6 & 7 & 8 & 9 & 10 \\
\hline \multirow[t]{2}{*}{ Potencial } & TS. Manejo & Prod. & Despesa & Receita & M.bruta & Área & Area total & Area total & Area prod. & Area p.acu & |Prod. total \\
\hline & & f(tha ano) & (U\$:s/ha p.an | & |US/ha p. anj & (U\$/ha p. an] & (ha) & I (ha) & (19000 ha) & ((1000 ha) &.$(1000 \mathrm{ha})$ & $\mid(1000$ Uano $) \mid$ \\
\hline \multirow[t]{2}{*}{$M$ alto } & 11a & 80.00 & 603,04 & 920 & $316,96 \mid$ & 10215,98 & 10215,98 & $10,22 \mid$ & $10,22 \mid$ & 10,221 & 817,28 \\
\hline & 116 & 80.50 & $615,27 \mid$ & $925,75 \mid$ & 310,48 & $6164.81 \mid$ & $16380,79 \mid$ & 16,38 & $6.16 \mid$ & $16,38 \mid$ & 496,27 \\
\hline \multirow[t]{4}{*}{ Alto } & |2a & $79,00 \mid$ & $613,73 \mid$ & 908,51 & $294,77 \mid$ & $12505,76 \mid$ & $28886,55 \mid$ & 28,89 & $12,51 \mid$ & $28,89 \mid$ & 987,96 \\
\hline & $2 \mathrm{~b}$ & $81,50 \mid$ & 604,58 & $937,25 \mid$ & $332,67 \mid$ & 4579,58 & 33466,13 & $33,47 \mid$ & $4,58 \mid$ & $33,47 \mid$ & 373,24 \\
\hline & 3a & $78,00 \mid$ & $636,26 \mid$ & $897 \mid$ & 260,74 & $|14267,14|$ & 47733,26 & 47,731 & $|11,89|$ & $45,36 \mid$ & 927,36 \\
\hline & j4b & 80,001 & 621,31 & 920ㅣㅣ & 298,69 & $3170,48 \mid$ & 50903,74 & 50,901 & $2,64 \mid$ & $48,00 \mid$ & 211,37 \\
\hline \multirow[t]{4}{*}{ Medio } & $16 a$ & 78,501 & $\mid 619,77$ & $902,75 \mid$ & 282,98 & 5636,401 & 56540,14 & 56,541 & 4,701 & $|52,69|$ & 368,71 \\
\hline & $16 b$ & $82,00 \mid$ & 611,65 & 943 & 331,35 & $3875,03 \mid$ & 60415,16 & 60,421 & 3,231 & 55,921 & 277,71 \\
\hline & 162 & $71,50 \mid$ & 629,61 & $822,25 \mid$ & 192,64 & $9511,43 \mid$ & 69926,59 & $69,93 \mid$ & 7,931 & 63,851 & 566,72 \\
\hline & 17a & 70,00 & 624,95 & 8051 & 180,05 & $6517,09 \mid$ & 76443,68 & $76,44 \mid$ & $5,43 \mid$ & $69,28 \mid$ & 380,16 \\
\hline \multirow[t]{4}{*}{ Baixo } & 182 & 76,00 & 634,22 & $874 \mid$ & 239,78 & 33642,26 & 110085,94 & 110,09 & $28,04 \mid$ & 97,321 & 2130,68 \\
\hline & $19 a$ & 70,00 & 672,15 & 805 & 132,85 & 4227,30 & 114313,24 & 114,31 & 3,52 & 100,84 & 246,59 \\
\hline & $10 a$ & 73,00 & 666,79 & 839,5 & 172,71 & 1585,24 & 4) 115898,48 & 115,90 & $1,32 \mid$ & 102,16 & 96,44 \\
\hline & $10 b$ & 75,00 & 657,13 & 862,5 & 205,37 & 528,41 & $116426,80 \mid$ & 116,43 & $0,44 \mid$ & $102,60 \mid$ & 33,03 \\
\hline \multirow[t]{6}{*}{ M baixo } & 11a & 71,001 & 661,40 & $816,5 \mid$ & $155,10 \mid$ & 1409,10 & 117835,99 & 117,84 & $1,17 \mid$ & $103,77 \mid$ & 83,37 \\
\hline & 12a & 75,00 & 656,91 & 862,5 & 205,59 & 2642,06 & 120478,05 & 120,48 & 2,200 & 105,98 & 165,13 \\
\hline & [12b & 66,00 & 659,41 & 759 & 99,59 & 26949,04 & 147427,09 & 147,43 & 22,46 & $128,43 \mid$ & 1482,20 \\
\hline & 13a & 72,50 & 654,35 & 833,75 & 179,40 & 10392,11 & 157819,20 & 157,82 & $8,66 \mid$ & 137,09 & 627,86 \\
\hline & [13b & 67,50 & 660,94 & $776,25 \mid$ & 115,31 & 15852,38 & 3173671,58 & 173,67 & $13,21 \mid$ & 150,30 & 891,70 \\
\hline & 1 & 1 & i & 1 & i & I & & 1 & 1 & & \\
\hline
\end{tabular}

\begin{tabular}{|c|c|c|c|c|c|c|c|c|c|c|c|}
\hline \multirow{2}{*}{\multicolumn{2}{|c|}{\begin{tabular}{|c|c|}
11 & 1 \\
P. total acu & M bruta \\
\end{tabular}}} & 13 & 14 & & & 1 & 16 & 16 & 17 & 18 & \\
\hline & & M b.t.ac. | & Mbruta & Potencial & S. Manejo & Cenário & Area total p |f & Pod total & M bruta & M bruta total & \\
\hline (1000t) & (1000 U\$) & (1000 U\$) & Us/ha t. $x$ an & & & & (1000 ha) & $(1000 t / a n o)$ & (UStha $x$ an fif & (1000 U\$) & \\
\hline 817,28 & $3238,01 \mid$ & $3238,01 \mid$ & 316,956 & $M$ alto & 1 a & & & & & & \\
\hline 1313,55 & $1914,08 \mid$ & 5152,09 & 310,48 & & $11 \mathrm{~b}$ & 1 & 16,38 & 1313,55 & $314,52 \mid$ & $5152,09 \mid$ & \\
\hline 2301,50 & 3686,32 & $8838,41 \mid$ & 294,77 & Alto & $2 a$ & & & & & & \\
\hline 2674,74 & 1523,49 & 10361,90 & 332,67 & & $2 \mathrm{~b}$ & & & & & & \\
\hline 3602,10 & 3099,98 & 13461,88 & 217,28 & & $3 a$ & & & & & & \\
\hline 3813,46 & $789,16 \mid$ & 14251,03 & 248,91 & & $4 b$ & 2 & 48,00 & 3813,46 & 283,41 & 14251,03 & \\
\hline 4182,18 & 1329,13 & $15580,17 \mid$ & 235,81 & Medio & $6 a$ & & & & & & \\
\hline 4459,89 & 1205,32 & 16785,49 & 311,05 & & $16 b$ & & & & & & \\
\hline 5026,61 & 1526,90 & 18312,39 & 160,53 & & 62 & & & & & & \\
\hline 5406,78 & 977,85 & $19290,24 \mid$ & 150,04 & & $7 a$ & 3 & 69,281 & 5406,78 & 256,96 & 19290,24 & \\
\hline 7537,45 & $6722,40 \mid$ & $26012,64 \mid$ & 199,82 & Baixo & 82 & & & & & & \\
\hline 7784,04 & $468,01 \mid$ & 26480,65 & 110,71 & & $9 a$ & & & & & & \\
\hline 7880,48 & 228,15 & $26708,80 \mid$ & 143,92 & & $10 a$ & & & & & & \\
\hline 7913,51 & $90,43 \mid$ & $26799,23 \mid$ & 171,14 & & $10 b$ & 4 & 102,60 & 7913,51 & 234,50 & 26799,23 & \\
\hline $7996,88 \mid$ & $182,13 \mid$ & 26981,36 & 129,25 & M. baixo & 11a & & & & & & \\
\hline $8162,01 \mid$ & 452,65 & 27434,01 & 171,32 & & $12 a$ & & & & & & \\
\hline 9644,20 & $2236,57 \mid$ & $29670,58 \mid$ & 82,99 & & $12 b$ & & & & & & \\
\hline $10272,06 \mid$ & $1553,61 \mid$ & $31224,18 \mid$ & 149,50 & 1 & $13 a$ & & & & & & \\
\hline $111163,76 \mid$ & $1523,22 \mid$ & 32747,41 & 96,09 & & $13 b$ & 5 & $137, \overline{16 \mid}$ & $10187,01 \mid$ & $211,56 \mid$ & 29922,99 & \\
\hline i & i & 1 & 1 & & I & & I & & & & \\
\hline
\end{tabular}




\section{ANEXO 8}

Sistema Produção de Eucalipto e Pastagen 


\section{Anexo 8}

A. Custo médio de reforma de Eucalipto

\begin{tabular}{lll}
\hline Operaçð̃es & Areas acidentadas & Areas planas \\
\hline & $\mathrm{U} \$ / \mathrm{ha}$ & $\mathrm{U} \$ \mathrm{ha}$ \\
preparo do solo (1) & 308,63 & 199,27 \\
produção de mudas & 88,4 & 88,4 \\
(2) & & \\
plantio (3) & 52,35 & 59,96 \\
manutenção (4) & 142,89 & 124,96 \\
transporte (5) & 57.91 & 77,37 \\
administração (6) & 69,56 & 40,38 \\
\hline total & 719,74 & 590,34 \\
\hline
\end{tabular}

1- Limpeza quimica, sulcamento, subsolagem, roçada e rebaixamento de touças e adubação ( $180 \mathrm{~kg}$ de superfosfato triplo e $130 \mathrm{~kg}$ de 20:00:20 por ha).

2-Mudas por semente.

3-Plantio de 1850 mudas/ha, e replantio (4\%) e irrigaçao.

4- Combate a pragas, roçadas e capinas quimicas, mecanicas e manuais até aproximadamente 9 meses.

5- Pessoal, mudas, marterial e insumos.

6- Administração de campo

B. Custo de manutenção (7):

Áreas planas: U\$ 35,00/ha ano

Áreas acidentadas U\$ 45,00/ha ano

7- Desbrota, roçadas, capinas, adubação, proteção (pragas, doenças e incendios), infraescrutura, transporte e administração.

Volume médio de madeira total: 630 st/ha em 2 cortes (14 anos)

\begin{tabular}{llll}
\hline & & Plana & Acidentada \\
\hline Reforma (plantio) & U\$/ha & 590,34 & 719,74 \\
Manutenção (13 anos) & U\$/ha & 455,00 & 520,00 \\
Subtotal & U\$/ha & 1045,34 & 1239,74 \\
Produção & st/ha & 630,00 & 630,00 \\
\hline Custo final & U\$/st & 1,66 & 1,97 \\
\hline \hline
\end{tabular}


RENDIMENTO MÉDIO DE UM SISTEMA DE PECUÁRIA EXTENSIVA COM BAIXO NÍVEL DE MANEJO:

PASTEJO CONTÍNUO

PERÍODO DE ENGORDA: 2,5 ANOS

\begin{tabular}{lc}
\hline Item & Custo unitário \\
\hline & Us \\
Bezerro & 120,00 \\
2,5 anos de engorda & 75,00 \\
Sal mineral + vaqueiro + prod. vet & 30,00 \\
\hline Custo total produção & 225,00 \\
Receita total (boi c/ 15 arrobas) & 300,00 \\
Margem bruta líquida (2,5 anos) & 75,00 \\
\hline Margem bruta ano & 30,00 \\
\hline \hline
\end{tabular}



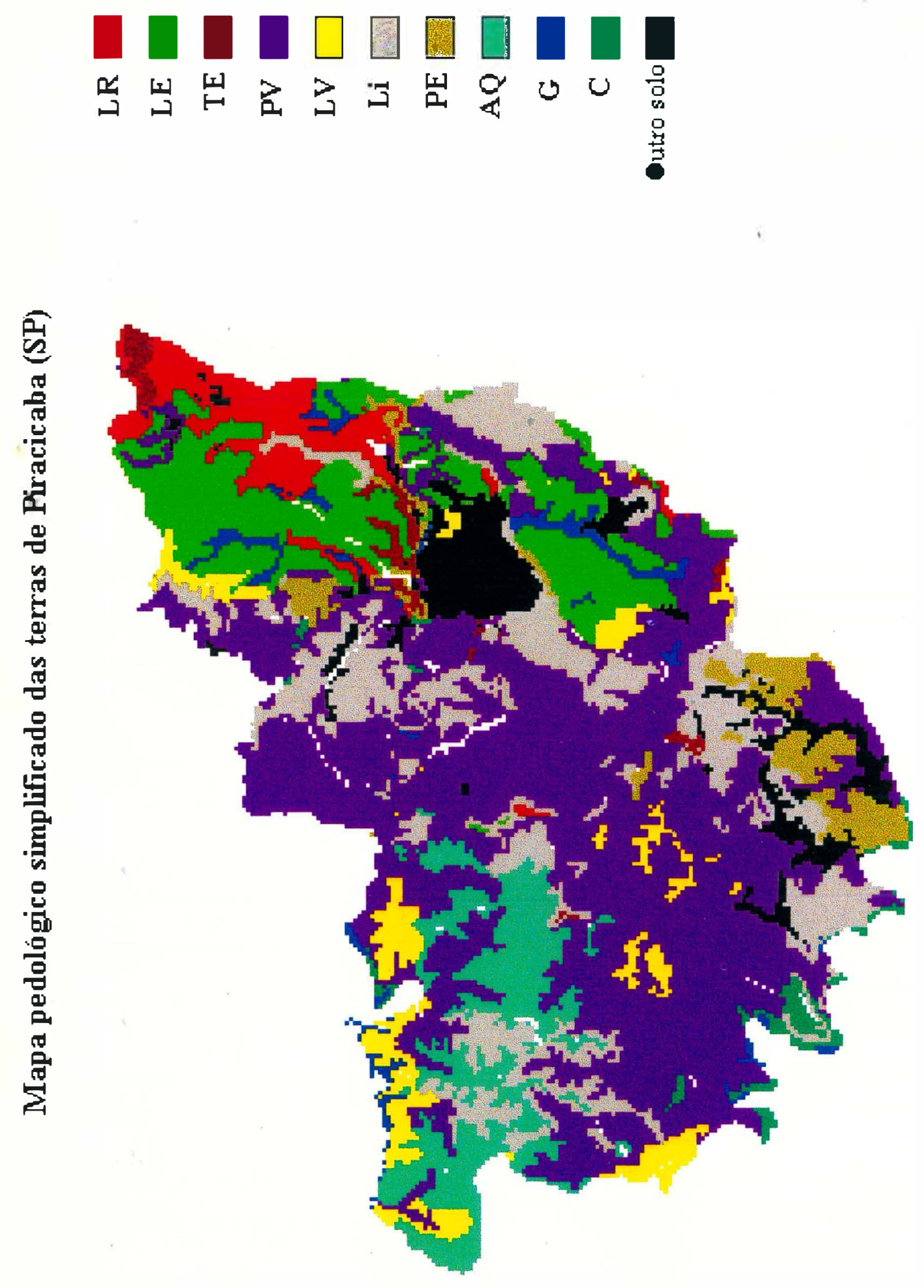


\section{QIIII}

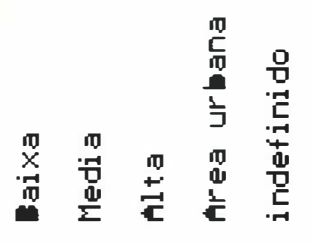

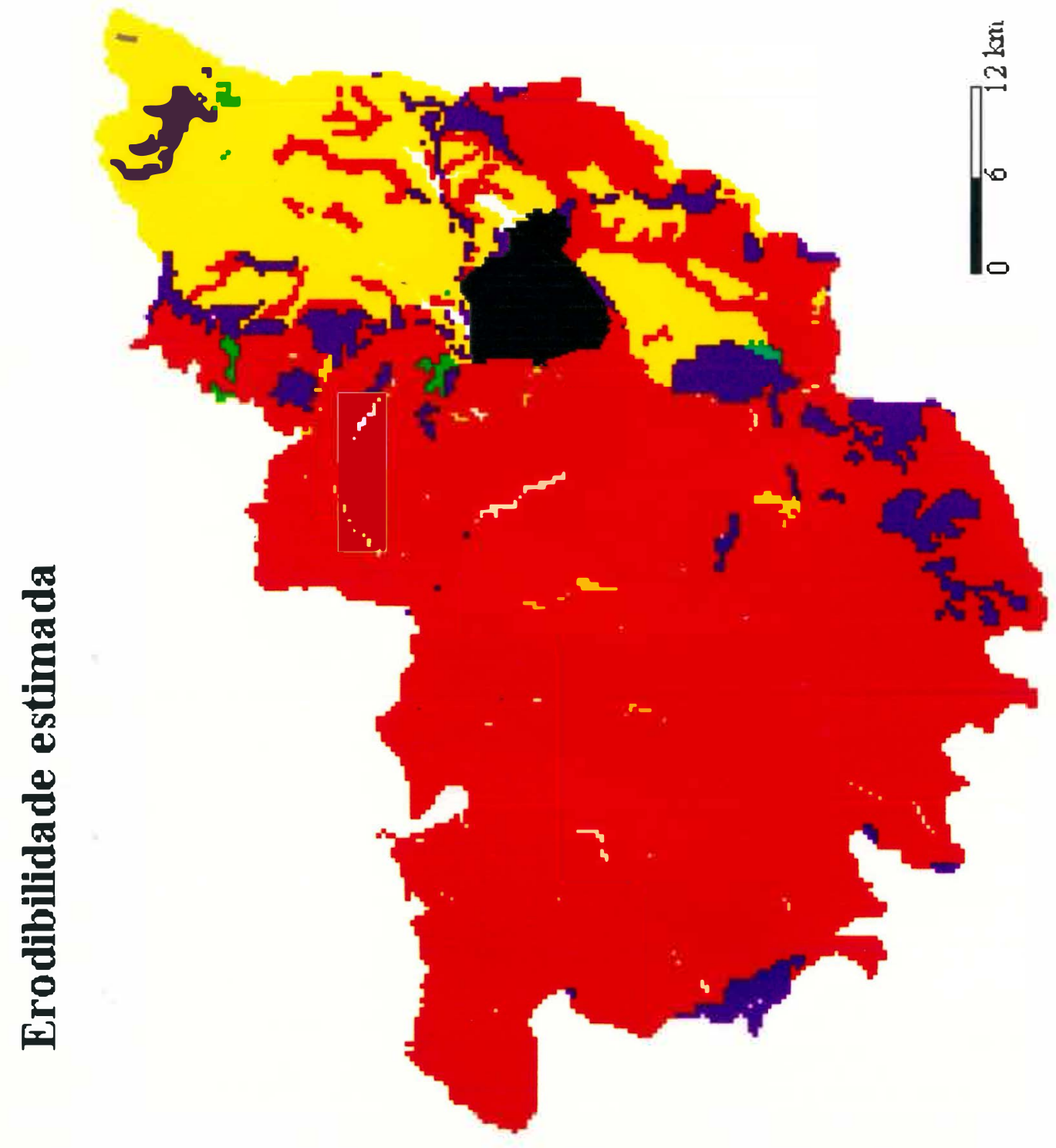



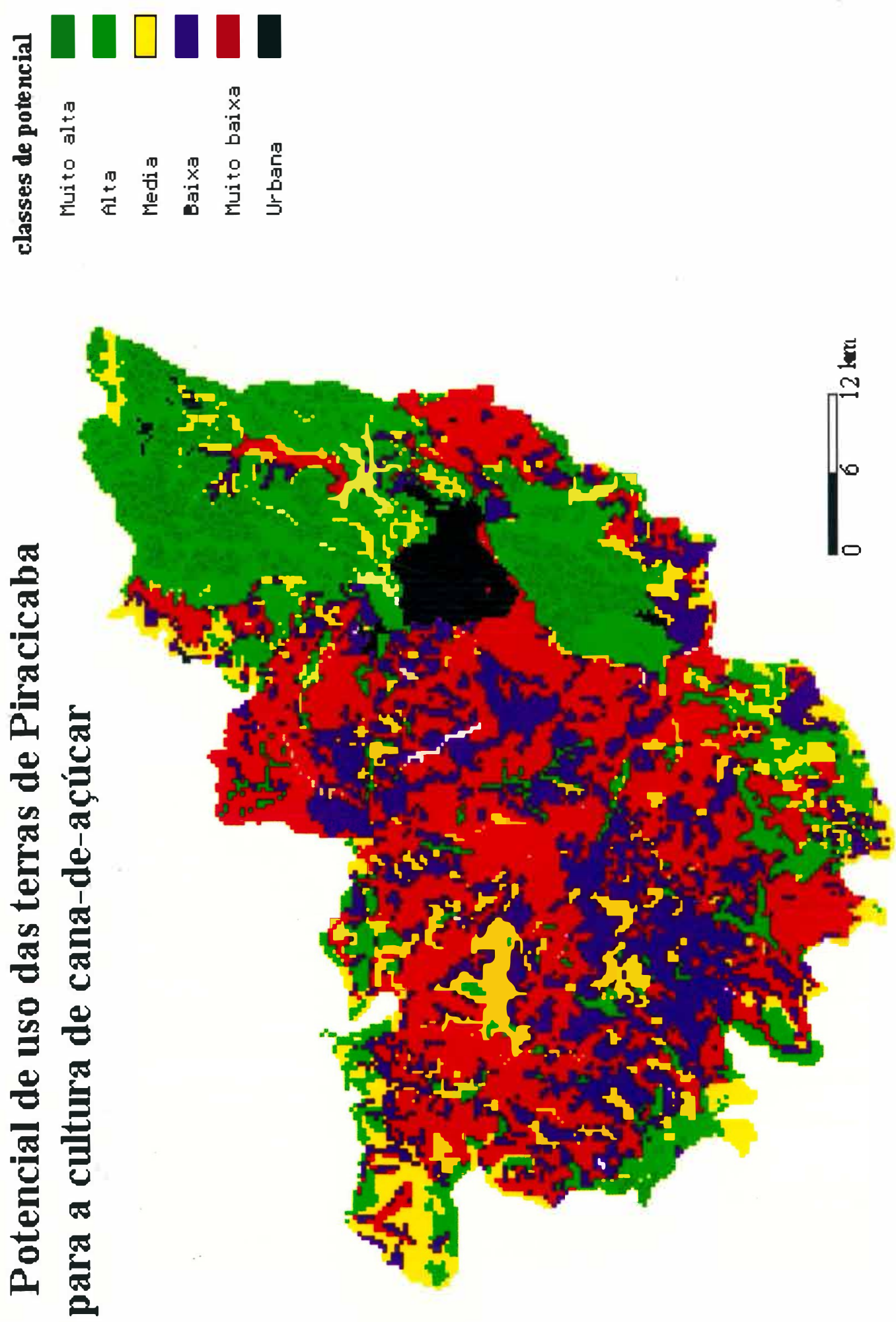

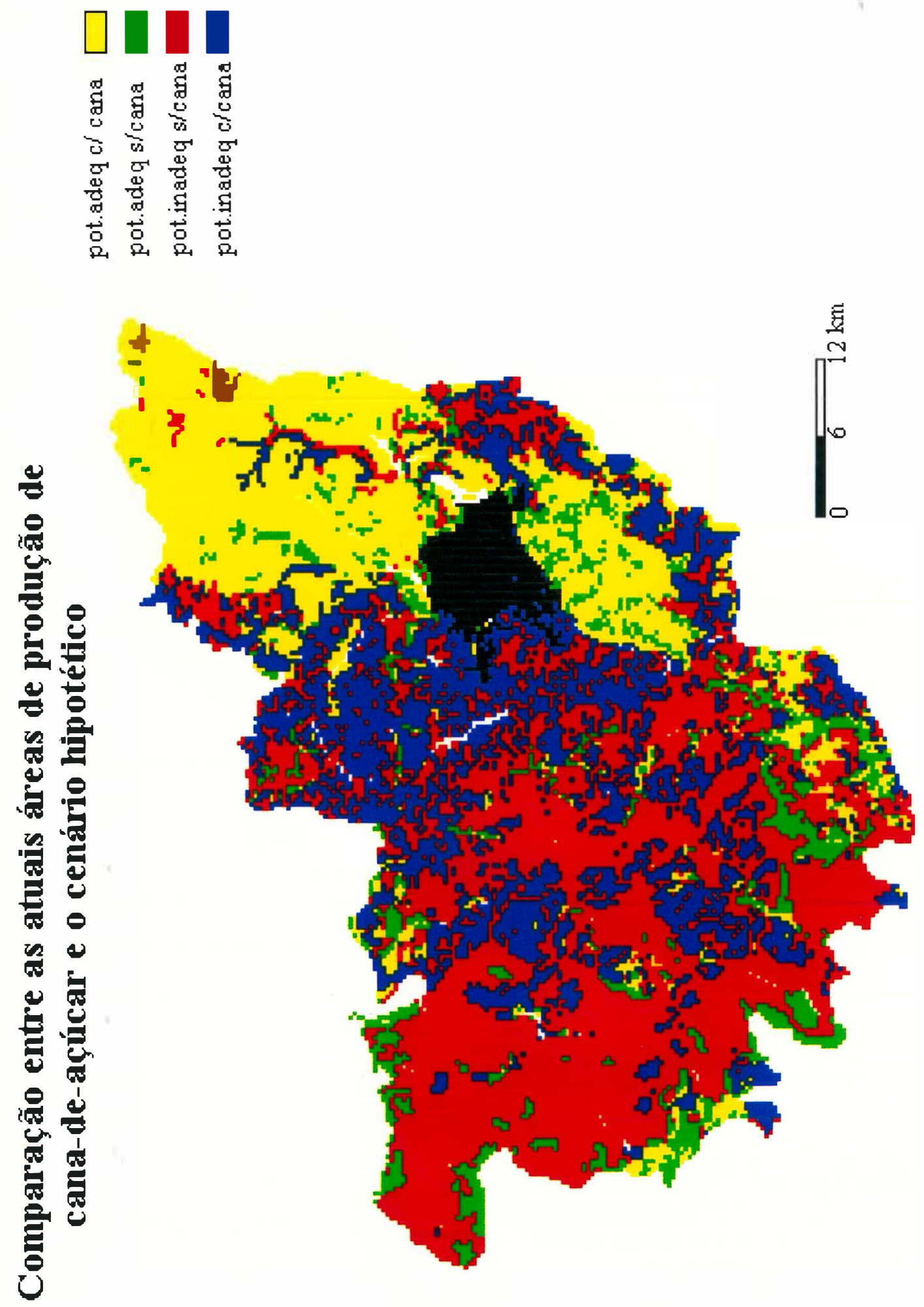